-

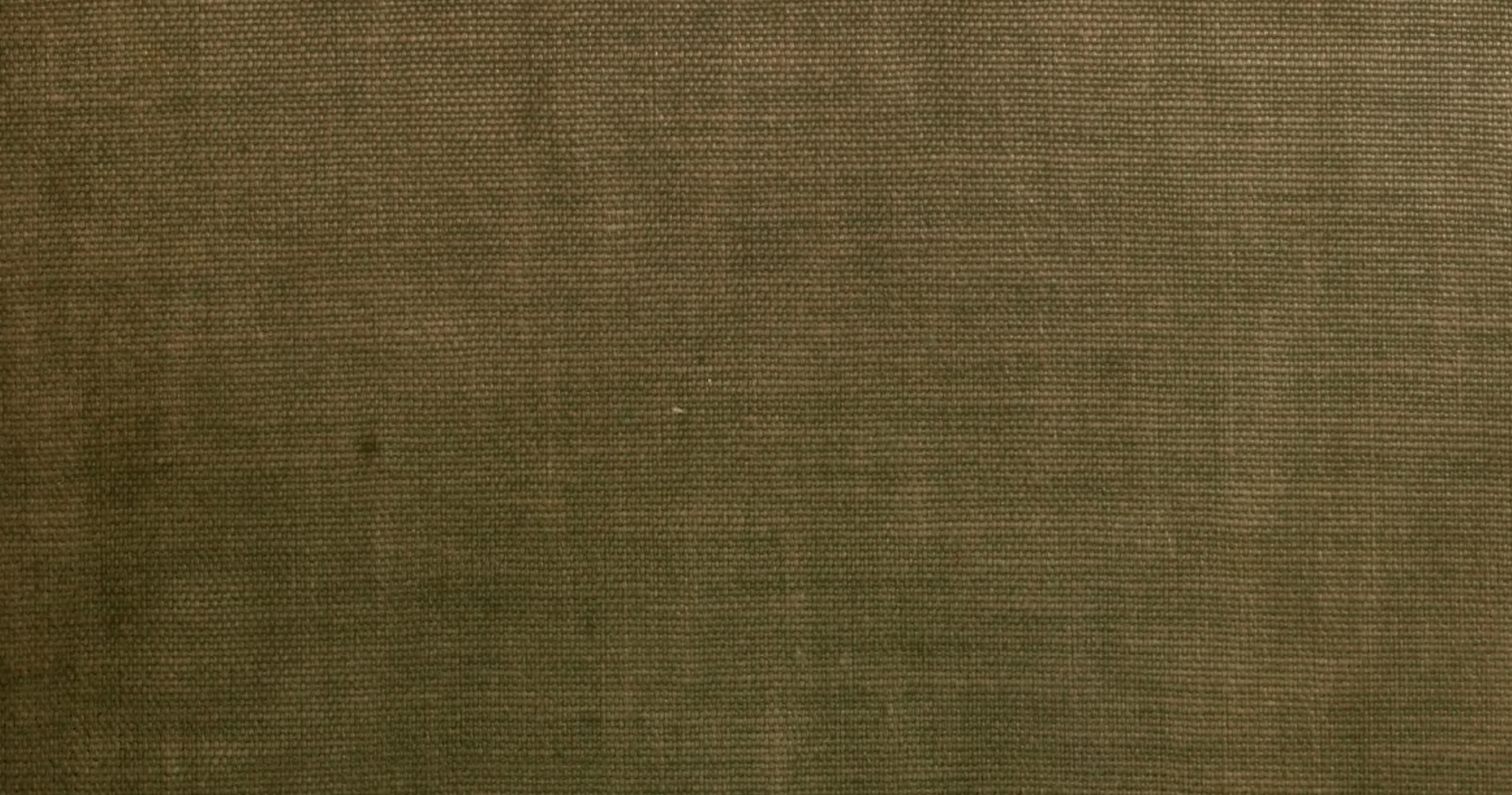





\section{nDemoirs of the IDuseum of Comparative $\mathbb{Z}$ oology}

A'T HARVARD COLLEGE.

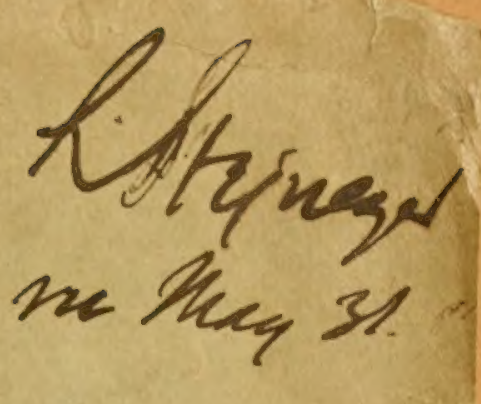

Vol. XLVII. No. 2.

\section{THE HERPETOLOGY OF CUBA.}

BY

THOMAS BARBOUR AND CHARLES T. RAMSDEN.

WITH FIFTEEN PLATES.

CAMBRIDGE, U. S. A.:

Drinted for the nDuseum.

MAX, 1919. 

ADemoirg of the ADuseum of Comparative Zoölogn

AT HARVARD COLLEGE.

Vol. XLVII. No. 2.

\title{
THE HERPETOLOGY OF CUBA.
}

\author{
BY \\ THOMAS BARBOUR AND CHARLES T. RAMSDEN.
}

WITH FIFTEEN PLATES.

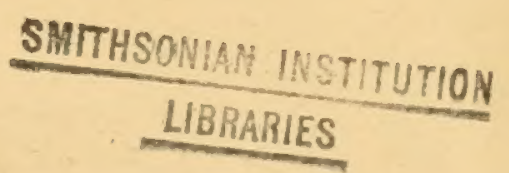

CAMBRIDGE, U. S. A.:

Drinted tor the nDugeum.

Max, 1919. 
Isonian Institut/o

STEJNEGER COLLECTION

National Museu' 


\section{CONTENTS.}

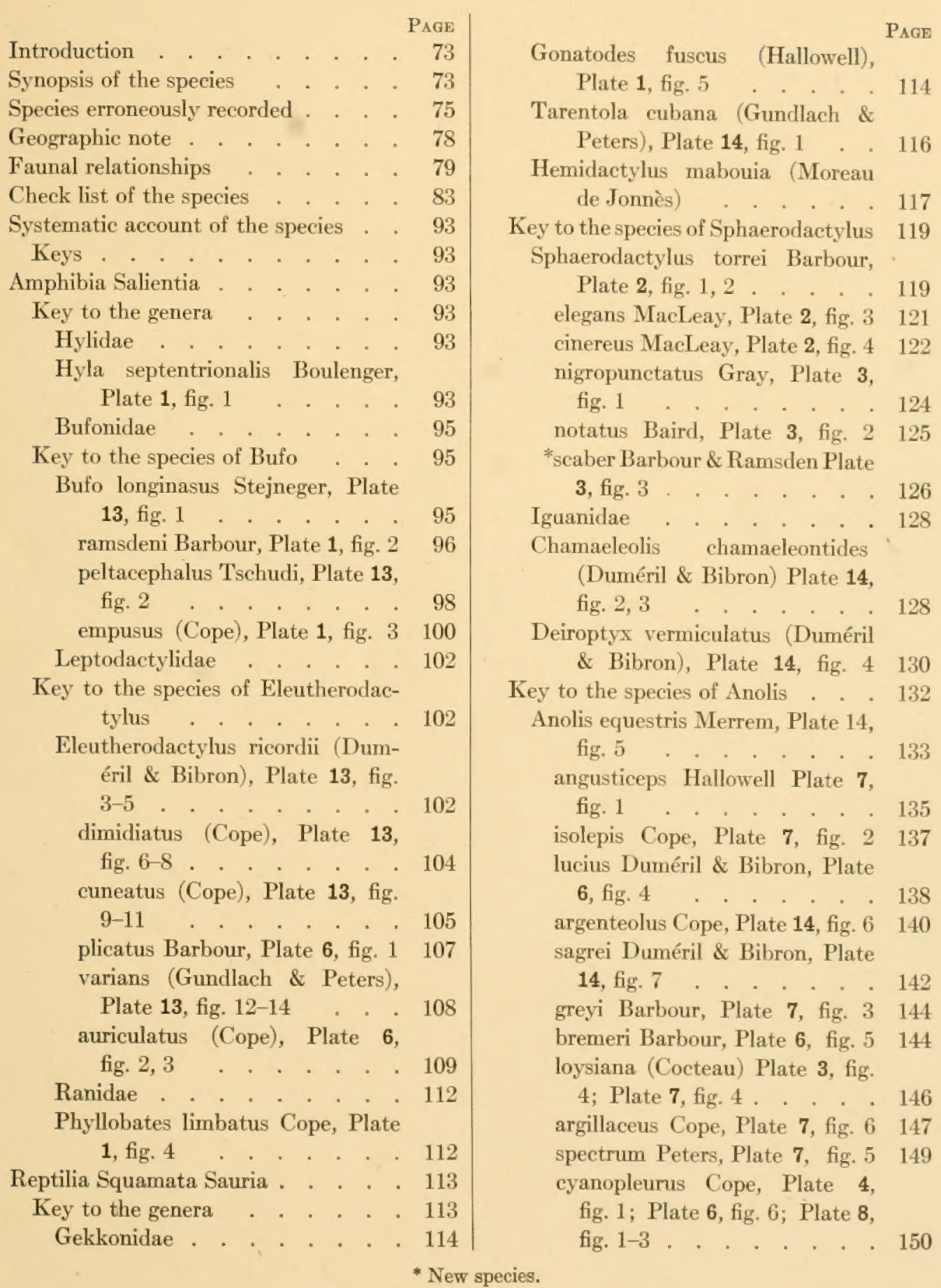




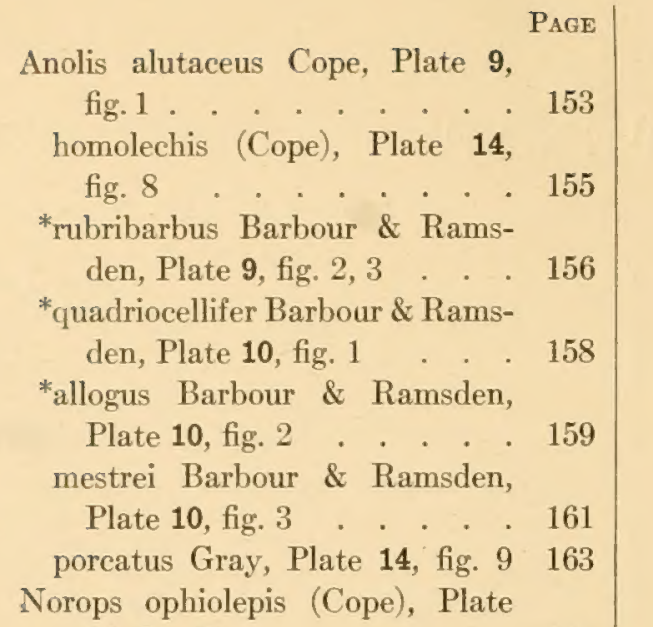

14, fig. 10 . . . . . . 164

Cyclura macleayi Gray, Plate 11, fig, 2,3 . . . . . .

Key to the species of Leiocephalus

Leiocephalus carinatus Gray, Plate 14, fig. 11 cubensis (Gray) Plate 14, fig. 12

raviceps Cope, Plate 10, fig. 4 macropus Cope, Plate 10, fig.

5 . . . . . .

Anguidae . . . . . . .

Celestus de la sagra (Cocteau),

Plate 14, fig. 13 . . . . . 175

Xantusiidae . . . . . 177

Cricolepis typica (Gundlach \&

Peters), Plate 4, fig. 2; Plate 11, fig. 1

Teiidae

Ameiva auberi Cocteau, Plate 14, fig. 14

Amphisbaenidae

Cadea blanoides Stejneger, Plate 15, fig. 1 . . . . . . Amphisbaena cubana Peters,

Plate 15, fig. 2 . . . . . 183

Reptilia Squamata Serpentes . . . 185

Key to the genera . . . . . . 185

Typhlopidae
Typhlops lumbricalis (Linné),

Plate 11, fig. 4, 5 . . . . . 185

Boidae . . . . . . . 186

Epicrates angulifer Bibron, Plate 15, fig. 3 . . . . . 186

Key to the species of Tropidophis 188

Tropidophis melanurus (Schlegel),

Plate 5, fig. 1 . . . . . 188

pardalis (Gundlach), Plate 5, fig. 2 . . . . . . 189 maculatus (Bibron), Plate 5, fig. 3. . . . . . . 190 semicinctus (Gundlach \& Peters)

Plate 15, fig. 4-6 . . . . 191

Natricidae . . . . . . . 192

Tretanorhinus variabilis Duméril \& Bibron, Plate 5, fig. 9192 Alsophis angulifer (Bibron), Plate 15, fig. 7 . . . . . . 194

Leimadophis andreae (Reinhardt \& Lütken), Plate 15, fig. 8 . 195

Key to the species of Arrhyton 197 Arrhyton taeniatum Günther,

Plate 15, fig. 10, 11 . . . 197 vittatum (Gundlach \& Peters), Plate 15, fig. 12, 13 . . . 199 redimitum (Cope) . . . . . 200

Reptilia Testudinata . . . . . . 200

Testudinidae . . . . . . . 200

Pseudemys palustris (Gmelin), Plate 15, fig. 14-16 . . 200 Reptilia Loricata . . . . . . . 202 Crocodylidae . . . . . . 202

Key to the species of Crocodylus 202 Crocodylus acutus Cuvier, Plate 12, fig. 1 . . . . . . . 202 rhombifer Cuvier, Plate 12, fig. 2203 Postscript . . . . . . . . . . 211

*Sphaerodactylus intermedius Barbour \& Ramsden . . . . 211

Natrix compressicauda (Kennicott) . . . . . . . 21

Explanation of the Plates 


\title{
THE HERPETOLOGY OF CUBA.
}

\author{
INTRODUCTION.
}

No previous attempt has been made to produce a complete list of the amphibians and reptiles of Cuba with descriptions of the species. It should be expressly understood that the senior author is responsible for the actual writing of this paper, for the nomenclature, and taxonomic descriptions, and the junior author has contributed many details of distribution and notes upon habits and habitats; his work has been chiefly in the Guantanamo Basin, and of this region he has the intimate knowledge which only long residence can give. The senior author besides having been privileged to collect with his associate upon Monte Libano, and elsewhere about Guantanamo, has visited various chosen localities in all of the other provinces, usually several times. Thus one or other of the writers has himself collected, with a few exceptions, every definitely known Cuban reptile or amphibian.

In 1880 Gundlach published his classic Erpetologia Cubana in Havana and in the natural course of events many changes have taken place since that time which have affected the nomenclature and status of the species treated, while new forms have been discovered.

\section{SYNOPSIS OF THE SPECIES.}

GUNDLACH in 1880 recognized fifty-four species of reptiles (aside from marine tortoises) and twelve species of amphibians. In 1914, only sixty-three species altogether were recognized (Barbour, Reptiles and Amphibians of the West Indies, Mem. M. C. Z., 44), many of Gundlach's names being reduced to the synonymy, or otherwise disposed of, and but comparatively few new species described. The following comparative table shows the present status of the species mentioned in Gundlach's Erpetologia Cubana, (Habana 1880, p. 1-99). 


\section{Name in Gundlach ${ }^{1}$}

Emys rugosa

Crocodilus rhombifer

$$
\text { americanus }
$$

Ameiva auberi

Leiocephalus carinatus

$$
\begin{aligned}
& \text { vittatus } \\
& \text { macropus } \\
& \text { raviceps }
\end{aligned}
$$

Cyclura carinata

Anolis equestris

$$
\begin{aligned}
& \text { fernandinae } \\
& \text { porcus } \\
& \text { vermiculatus } \\
& \text { carolinensis } \\
& \text { sagrae } \\
& \text { lucius } \\
& \text { argenteolus } \\
& \text { angusticeps } \\
& \text { isolepis } \\
& \text { ophiolepis } \\
& \text { cyanopleurus } \\
& \text { alutaceus } \\
& \text { spectrum } \\
& \text { loysiana } \\
& \text { argillaceus }
\end{aligned}
$$

Platydactylus cubanus

Hemidactylus mabuia introduced

Sphaeriodactylus sputator

$$
\begin{aligned}
& \text { cinereus } \\
& \text { argus } \\
& \text { notatus } \\
& \text { fantasticus }
\end{aligned}
$$

Gymnodactylus albogularis

Cricosaura typica

Diplogossus sagrae

Amphisbaena punctata

$$
\text { cubana }
$$

Typhlops lumbricalis

Ungalia melanura

$$
\begin{aligned}
& \text { maculata } \\
& \text { semicincta }
\end{aligned}
$$

Epicrates angulifer

Urotheca dumerilii undoubtedly not Cuban

Cryptodacus vittatus

Arrhyton taeniatum

fulvum
Name in present use. ${ }^{2}$

Pseudemys palustris

Crocodylus rhombifer

acutus

Leiocephalus macleayi

Cyclura cyclura

Chamaeleolis chamaeleontides chamaeleontides

Deiroptyx vermiculatus

Anolis porcatus

sagrei

Norops ophiolepis

Tarentola cubana

Hemidactylus mabouia

Sphaerodactylus torrei

cinereus

cinereus

notatus

scaber

Gonatodes fuscus

Cricolepis typica

Celestus de la sagrae

Cadea blanoides

Trophidophis melanurus maculatus semicinctus

\section{Arrhyton vittatum}

Arrhyton taeniatum

${ }^{1}$ Listed in Gundlach's sequence.

${ }^{2}$ An omission indicates no change from Gundlach's name. 
Colorhagia redimita

Dromicus angulifer

adspersus

fugitivus

temporalis undoubtedly not Cuban

Tretanorhinus variabilis

Tropidonotus cubanus anoscopus

Peltaphryne peltacephalus empusa

Phyllobates bicolor probably Mexican limbatus

Trachycephalus marmoratus insulsus

Hylodes dimidiatus wrightii

auriculatus ricordii

varians

cuneatus
Arrhyton redimitum

Alsophis angulifer angulifer

Leimadophis andreae

Urotheca lateristriga

Natrix compressicauda

?Natrix rhombifer, or perhaps an African species.

Bufo peltacephalus empusus

Hyla septentrionalis septentrionalis septentrionalis

Eleutherodactylus dimidiatus auriculatus ricordii varians cuneatus

\section{SPECIES ERRONEOUSLY RECORDED.}

Many species either through a misplaced label, in the museum or in the field, have been recorded from localities which know them not. Errors arise also from mistaking a species which has been accidentally or purposely introduced for a native form. C $C f$. Gundlach's account of Hemidactylus mabouia (Erp. Cub., 1880, p. 55).

\section{Cayman sclerops (Schneider).}

While this alligator is really South American, it has been recorded from Cuba by Gray (Ann. mag. nat. hist., 1840, 5, p. 115).

\section{Testudo denticulata Linné.}

This species, usually known by the name of Testudo tabulata Walbaum, has been often carried about alive and hence has been recorded from many of the Antilles, from Cuba and Porto Rico among others. It is confined to the South American mainland. 


\section{Testudo polyphenios Daudin.}

Really confined to Florida, but recorded by Gray from Cuba (Ann. mag. nat. hist. 1840, 5, p. 115).

\section{Cinosternon bauri Garman.}

A Floridian tortoise; one of the types was said to have been sent to the M. C. Z. by Filipe Poey, from Cuba. Either Professor Poey obtained the specimen from Florida and neglected to mention the fact, or an incorrect label was substituted for the original after it was received at the Museum. There is an example of Gerrhonotus in the U.S. N. M. which has suffered exactly the same vicissitudes, bearing now a Poey label.

\section{Natrix anoscopa (Cope).}

This was probably based on a specimen from the southern United States, although Stejneger thinks Cope may have had an African form. The evidence that Gundlach ever found a Natrix in Cuba is extremely unconvincing, since none has been found there by any other collector. It is quite probable that his Tropidonotus cubanus (Erp. Cubana, 1880, p. 81) was really based on an anomalous example of the "catibo" (Tretanorhinus variabilis). There is no specimen of Natrix (Tropidonotus auct.) in the Museo Gundlach of the Instituto de Segunda Ensenanza in Havana. (See Postscript, p. 212).

\section{Leimadophis parvifrons (Cope).}

Under the name of (Liophis) parvifrons Meerwarth records (Mitth. Natur. mus. Hamb., 1901, 18, p. 15), a specimen of this Haitian species from Cuba. The specimen apparently entirely lacks definite data. That this record should not be queried by Meerwarth will hardly surprise one who consults this paper, for on page 9 it is stated that the Hamburg museum possesses Constrictor (called Boa) imperator from St. Thomas!

\section{Dromicus temporalis Cope.}

This species and a so-called Scoliophis fumiceps were described from specimens said to have been in the M. C. Z. The type of the latter cannot be found 
but it is evidently a Tantilla. The type of $D$. temporalis is referable to Urotheca lateristriga. Both examples doubtless came from Central America and not Cuba as Cope records.

\section{Urotheca dumerili Bibron.}

Only known from Cuba through the collections sent to Paris by Ramon de la Sagra. Never since that time has the species been found in Cuba. The other species of the genus are all from the mainland. Prof. de la Torre tells us that a number of species of molluses from the Central American mainland were reported as coming from Cuba by d'Orbigny, also from the collections of de la Sagra. Evidently de la Sagra shipped material from the mainland to Paris with his Cuban collections and as these bear no definite localities in the published accounts it is quite likely that no label was sent with any of the specimens and that it was simply assumed that all came from Cuba.

We suspect that possibly the reverse occurred with the collections of Morelet, who gathered material first in Cuba, then went to Central America, whence probably all was sent to Europe. Thus the Cuban species Crocodylus rhombifer and Tropidophis semicincta may have been carried to Central America and possibly these appear now as Crocodylus moreleti and Tropidophis morcleti from Central America, where they do not seem to be found by recent collectors. Regarding the latter possibility $c f$. Stejneger (Proc. U. S. N. M., 1917, 53, p. 281).

\section{Phyllobates bicolor Bibron.}

This species so beautifully figured by Bibron in the Histoire of de la Sagra has never been discovered in any collection made in Cuba since de la Sagra's time and it certainly appears as if the history of this species is the same as that of Urotheca dumeritii.

\section{Bufo Marints (Linné).}

Meerwarth records a specimen from Cuba and tersely remarks that it is typisch. No great surprise if he really had marinis which is not found in Cuba (Mitth. Natur. mus. Hamb., 1901, 18, p. 40).

\section{Hemidactylus mabouia (Moreau).}

This species has a somewhat different history from those preceding. It is one which has been carried far and wide through tropical America from Africa, 
probably during the slave-trade. Gundlach evidently did not know that it was not a native Cuban species. ( $C f$. Erp. Cub. 1880, p. 55). A detailed description of this species is given in its systematic position on p. 117 .

\section{GEOGRAPHIC NOTE.}

Cuba, the largest and richest of all the West Indies, has an area all told, including the outlying cayos, of about 123,000 square kilometers. The Island is about 1,200 kilometers long and varies greatly in breadth, from 40 to 200 kilometers. It is distant 210 kilometers east of Yucatan, about 180 kilometers south of Florida, and 77 west of Haiti. Generally speaking the rainfall increases as one passes eastward through the island. The central provinces of Havana, Matanzas, Santa Clara, and Camaguey are in great part level, devoted to the cultivation of sugar-cane or the raising of cattle and horses. Even in these provinces there are ranges of rounded hills composed of metamorphosed igneous rocks as well as scattered remnants of limestone either in the form of isolated hillocks or mogotes as they are called locally, or more extensive chains called sierras in contradistinction to lomas, the term sometimes used for hills other than those of limestone. In Pinar del Rio and far more so in Oriente the limestone ranges are well developed and reach considerable heights. Pico Turquino has an estimated altitude of 2,400 meters and is the highest summit in Cuba. Spanish language and custom combine to endow any land colonized by Spain with a marvellously complete equipment of place-names and every brook, spring, hillock, or dale whether inhabited or not, if it has ever been visited at all, has some often wonderfully trite name. No one unfamiliar with the local idiom would believe that so great a series of beautifully differentiating names were available for every physiographic feature. This state of affairs makes it very simple to designate accurately the locality where one has collected. The only difficulty is that names often change. The student interested in the distribution of Cuban species will do well to consult the excellent map (in two large sheets) published by the U. S. War Department and the Geografia de la Isla de Cuba by Aguayo and de la Torre (Habana La Moderna Poesia, 1907). The latter which is the regular text-book of geography used in the Cuban schools is wholly excellent. 


\section{FAUNAL RELATIONSHIPS.}

There can be no reasonable doubt but that in the past Cuba has been subjected to a number of fundamental changes of level. Ammonites of Jurassic age are found in Pinar del Rio (Puerto de Ancon, Viñales, San Diego de los Baños) while in the central provinces Barettia, hippuritids and similar fossils bear evidence of depression there. Thus we may imagine Cuba as having been an archipelago by the evidence of these marine deposits and by the fact as well that so many of the sierras have their own very distinct faunulae of terrestrial molluses. These often point to curious possible connections in the past. The axis of the Sierra Maestra, if prolonged, would reach out to the Cayman Islands and to Swan Island and the relationships of the land shells suggest some such condition in the past. So also the molluses of the sierras of the Island of Pines and those of Camaguey point to a relationship far more intimate than exists at present. The amphibians and reptiles, because of their ability to spread with comparative ease in a region where no great natural barriers exist, are rather homogeneously distributed throughout the Island. Nevertheless there are conspicuous exceptions such as the two remarkable toads Bufo longinasus and B. ramsdeni.

The connection at some time in the past of Cuba with both Yucatan and Haiti is very strongly indicated by the fauna, not only among the reptiles and amphibians but in very many other groups. ${ }^{1}$

Since Cuba is by far the largest of the Antilles in area it is by no means surprising to find that it supports the largest number of species of reptiles and amphibians of any of the islands, there being no less than seventy species at present recorded. Two of these appear to have been introduced, while no less than fifty-two are peculiar to Cuba. The Cuban fauna differs in some important respects from that of either Jamaica, Haiti, or Porto Rico. The presence of Phyllobates, Tretanorhinus, Arrhyton, Norops, and Cricosaura bespeaks a close relationship to the neighboring continent, in which the other islands have not shared. So, also, the presence of no less than four species of Bufo, only one of which, B. empusus, has close allies in B. gutturosus of Haiti, B. lemur of Porto Rico, and B. turpis of Virgin Gorda. While of the others B. peltacephatus is not so very unlike some of the continental forms, but $B$. longinasus and $B$.

1 For a discussion of the Antillean land bridges sce Bull. M. C. Z, 1910, 52, p. 275-2S5; Mem. M. C. Z., 1914, 44, p. 214-237; Ann. N. Y. acad. sci., 1916, 27, p. 1-15. 
ramsdeni, while they are related to each other, have no close affinity with any Bufo anywhere. The single Hyla is decidedly similar to $H$.dominicensis of Haiti or $H$. brunnea of Jamaica. Upon Jamaica, however, another very peculiar Hyla, $H$. lichenata, is found with a possible ally, $H$. vasta, in Haiti; and there, still a third species, $H$. pulchrilineata, occurs with affinities to $H$. eximia of Mexico, $H$. andersonii of the white cedar swamps of the eastern United States and so to $H$. arborea of Europe. The beautiful little Phyllobates is the only species of its genus which is not found upon the mainland, except for $P$. trinitatis which is probably not congeneric. The Eleutherodactyli, six in number, embrace four which are peculiar to the island. These four might be said perhaps to be rather more like mainland than Antillean types; E. ricordii, however, is found in the Bahamas and Florida, having appeared there recently, and $E$. auriculatus is more common in Haiti and Porto Rico than it is in Cuba, its typelocality.

Among the reptiles Deiroptyx and Chamaeleolis are modifications of an Anolis-like stock, probably Anolis itself. Monotypic and confined to Cuba, they suggest that they have evolved rather recently, in spite of their great divergence from Anolis; for they have never spread elsewhere. Cricolepis, also monotypic, tells a different tale, for, although it too is peculiar to Cuba, it belongs to an archaic group which persists with but few species, almost all of which are rare and confined to extremely restricted habitats. The Norops is very like the continental species, and no other of the genus is found among the Antilles. The Celestus, the Cyclura, the four Leiocephali, and many of the species of Anolis are truly West Indian; that is, they belong to groups which appear to have evolved themselves upon the greater Antillean land area of which the West Indies are now the disrupted remnants. To this category belong several of the Sphaerodactyli, S. notatus, picturatus, elegans, cinereus, nigropunctatus, which are allied to corticolus of the Bahamas, leaving only $S$. torrei of the Cuban species without close relations outside of Cuba or occurring elsewhere among the islands. As a matter of fact, $S$. torrei is very possibly derived from some elegans-like ancestor, perhaps from elegans itself, and since elegans does not appear in eastern Cuba, although it is found in Haiti, it is possible that it really represents elegans thus modified in Oriente; for torrei seems to be found in Oriente only, the one province of Cuba from which elegans is wanting. It is perhaps more probably related to decoratus of the Bahamas. The Tarentola is an enigma; supposedly entirely confined to Cuba, it has been found recently in the Bahamas, upon Exuma, and being retiring and hard to find it 
may occur elsewhere in the region. Its relationships are, of course, Nediterranean.

Of the snakes Arrhyton with three species is confined to Cuba and probably represents some Leptocalamus-like ancestor, modified through isolation. The Alsophis and Leimadophis are really West Indian, while the Boas, one Epicrates, and no less than four Tropidophes are typically Greater Antillean. The Typhlops is insignificant, being very wide-ranging and a type likely to be transported fortuitously. The fresh-water tortoise is found upon the four greater islands; Crocodylus acutus, although wanting in Porto Rico occurs on the other three. Crocodylus rhombifer is peculiar to Cuba and has but one near ally in $C$. moreletii of Central America; if this species ever proves to be anything more than rhombifer with a wrong locality label.

The question of whether Cuba is a true continental island and whether or not it with the other West Indies has ever been joined together to form a far greater land mass than they do now, has been discussed elsewhere at length (see footnote p. 79). The discovery of fossil mammals, edentates, rodents, and an insectivore, unearthed in Cuba through Carlos de la Torre, Barnum Brown and the exploring parties from the M. C. Z., and the still more surprising collections made in Porto Rico by Franz Boas and Anthony and recently reported upon by J. A. Allen and Anthony, make it increasingly evident that this interpretation of the evidence of the amphibians and reptiles is the correct one. The significance of these fossil troves cannot be exaggerated and how much exploration remains to be done! A few years ago from densely populated and widely cultivated Porto Rico not a fossil mammal was known and some of the most learned palaeontologists did not postulate their presence there. Now several genera of rodents, an insectivore, and a sloth have been found and beyond doubt the end is not yet. Haiti is palaeontologically absolutely a terra incognita, or as perhaps we might better say in a paper upon Cuba, una tierra desconocida. If suitable deposits are found, and if fortune favors, there is no great doubt but that a considerable mammalian fauna will be uncovered in the future.

Perhaps the most interesting point which a study of the reptiles and amphibians brings out is that, although Cuba supports mainland types not found upon other islands, it has nevertheless in spite of the swift currents which sweep its shores and its proximity to Yucatan and Florida a typically West Indian fauna; those very forms being present in their reasonable proportion or representation, as so very many of them occur upon every island from Cuba to Grenada. It is 
this homogeneity of the fauna and the character of its components, their habits, and their life histories which are significant in answering those who believe that the West Indies were populated by "flotsam and jetsam" means. The eggs of Ameiva, in Jamaica at any rate, have been found by Dr. Grabham of Kingston to be laid three feet underground; probably for this reason Ameiva eggs have not been found elsewhere. Yet several writers have seriously suggested the importance of tropical hurricanes and ocean currents in carrying the eggs of those forms, whose adults even they admit could probably not be transported by any conceivable means. Every added observation to those now upon record makes it appear less probable that the eggs are more capable of fortuitous transportal than the adults.

The writers have to thank many who have helped in the preparation of this paper. First and foremost Dr. Leonhard Stejneger whose wise council has ever been generously given and who has allowed the use of a number of cuts. Then to Dr. Carlos de la Torre we are greatly indebted, for he has helped us beyond measure. Nor can the senior author fail to acknowledge the constant assistance received from Mr. W. S. Brooks, who has been his frequent and welcome companion during many voyages. Mr. Brooks though chiefly interested in ornithology and conchology has added very many amphibians and reptiles to our collections and his name should be associated with much of the material collected by the senior author since 1915. To our host of hospitable friends, Cuban and American alike, who have aided us in many ways it is impossible to express adequately our gratitude. It is useless to even attempt to number them since they were so many. We shall always remember, however, specially Señor don Francisco Morales and Señor Victor J. Rodriguez. 


\section{CHECK LIST OF THE SPECIES.}

Amphibia: Salientia.

1. Hyla septentrionalis Boulenger.

Boulenger, Cat. Batr. Sal. Brit. mus., 1882, p. 368; Barbour, Mem. M. C. Z., 1914, 44, p. 238.

Occurs throughout the Island.

\section{Bufo Longinasus Stejneger.}

Stejneger, Proc. U. S. N. M., 1905, 28, p. 765; Barbour, loc. cit., p. 210.

Known only from the type found at El Guamá, near Pinar del Rio City.

\section{Bufo RAMSdeni Barbour.}

Barbour, loc. cit., p. 240.

A few specimens only known. All from Monte Libano, near Guantanamo.

\section{Bufo peltacephalus Tschudi.}

Tschudi, Class. Batr., 1838, p. 52; Boulenger, loc. cit., p. 325; Barbour, loc. cit., p. 211.

Widely spread throughout the Island.

\section{Bufo empusus (Cope).}

Cope, Proc. Acad. nat. sci. Phila., 1862, p. 34t; Boulenger, loc. cit., p. 326; Barbour, loc. cit., p. 212.

Found where suitable local conditions obtain from Colon in the Province of Matanzas to the vicinity of the town of Herradura in Pinar del Rio. Exact limits of range unknown.

\section{Eleutherodactylus ricordi (Duméril \& Bibron).}

Duméril et Bibron, Erp. gén., 1814, p. 623; Boulenger, loc, cit., p. 213; Barbour, loc. cit., p. 243.

Found throughout the Island and in the Bahamas.

\section{Eleutherodactylus dimidatus (Cope).}

Cope, Proc. Acad. nat. sci. Phila., 1S62, p. 151; Barbour, loc. cit., p. 24.

Known only from the Province of Oriente. 


\section{Eleutherodactylus cuneatus (Cope).}

Cope, Proc. Acad. nat. sci. Phila., 1862, p. 152; Boulenger, loc. cit., p. 209; Barbour, loc. cit., p. 241.

A rare but apparently widespread species. It is known from Pinar del Rio, Santa Clara, and Oriente Provinces.

\section{Eleutherodactylus plicatus Barbour.}

Barbour, loc, cit., p. 241.

Known from a few specimens only, all from the region of Monte Libano near Guantanamo.

10. Eleutherodactylus varians (Gundlach \& Peters).

Gundlach und Peters, Monatsb. Akad. wiss. Berlin, 1864, p. 390; Boulenger, loc. cit., p. 215; Barbour, loc. cit., p. 245.

A rare species known from a few scattered localities.

\section{Eleutherodactylus auriculatus (Cope).}

Cope, Proc. Acad. nat. sci. Phila., 1862, p. 152; Stejneger, Rept. U. S. N. M., for 1902, 1904, p. 583, fig. 15-19.

Originally described from Oriente in Cuba, it has since been found in Haiti and Porto Rico.

\section{Phyllobates limbatus Copé.}

Cope, Proc. Acad. nat. sci. Phila., 1862, p. 154; Boulenger, loc. cit., p. 255; Barbour, loc. cit., p. 255.

First found near Guantanamo, rediscovered after many years near Cienfuegos, and now also known to be generally distributed on the mountain ranges of eastern Oriente. Recently found at San Antonio de los Baños, near Havana.

\section{Reptilia: Squamata, Sauria.}

\section{Gonatodes fuscus (Hallowell).}

Irallowell, Journ. acad. nat. sci. Phila., 1855, new ser. 3, p. 33; Barbour, Bull. M. C. Z., 1910, 52, p. 289; Mem. M. C. 7., 1914, 44, p. 256.

Cities of Cuba, principally found in buildings. Known also from Jamaica, where it has probably recently been introduced. 
14. Tarentola cubana (Gundlach \& Peters).

Gundlach und Peters, Monatsb. Akad. wiss. Berlin, 1861, p. 381; Boulenger, Cat. lizards Brit. mus., 1885,1 , p. 195; 1887, 3, p. 190 ; Barbour, loc. cit., p. 259.

A widespread, though generally rare, species. Recently found abundantly at Puerto Escondido, near Guantanamo, and near Baracoa, and known also from Exuma Island.

15. Hemidactylus mabouta (Moreau de Jonnès).

Mloreau de Jonnès, Bull. Soc. philom., 1818, p. 138.

Widely distributed in America.

16. Sphaerodactylus torrei Barbour.

Barbour, loc. cit, p. 260.

Not uncommon in the Province of Oriente; the species may occur also in Haiti. Taken in 1919 near Camoa, Havana Province.

17. Sphaerodactylus elegans MacLeay.

MacLeay, Proc. Zoöl. soc. London, 1834, p. 12; Boulenger, loc. cit., p. 220; Barbour, loc. cit., p. 261.

Possibly occurs throughout Cuba, but it is certainly most common in the western and central areas. Recently found in Haiti.

\section{Sphaerodactylus cinereus Macleay.}

MacLeay, Proc. Zoöl. soc. London, 1834, p. 12; Boulenger, loc. cit., p. 220; Barbour loc, cit., p. 201.

Distributed over the whole Island. Known also from Haiti.

\section{Sphaerodactylus nigropunctatus Gray.}

Gray, Cat. lizards Brit. mus, 1845, p. 169; Boulenger, loc. cit., p. 220, pI. 12, fig. 2; Barbour, loc. cit., p. 261.

Known only from Oriente.

20. Sphatrodactylus notatus Baird.

Baird, Proc. Acad. nat. sci. Phila., 1858, p. 251; Boulenger, loc. cit., p. 261; Barbour, loc. cit., p. 261.

Found throughout Cuba, the Bahamas, and in Key West. The Haitian specimens may be specifieally distinct. 
21. Sphaerodactylus scaber, sp. nov.

Probably found only in hills of eastern Santa Clara and western Camaguey. Closely related to $S$. picturatus which is widespread in Haiti.

\section{Chamaeleolis chamaeleontides (Duméril \& Bibron).} Duméril et Bibron, Erp. gén., 1837, 4, p. 168; Boulenger, loc. cit., 1885, 2, p. 7; Barbour, loc. cit., p. 271.

Widespread throughout the Island in the old high forests, but everywhere rare.

\section{Deiroptyx vermiculatus (Duméril \& Bibron).} Duméril et Bibron, Erp. gén., 1837, 4, p. 128; Boulenger, loc. cit., p. 41.

Found along streams and small rivers in Pinar del Rio. It enters the water to escape pursuit. Often considered an Anolis.

\section{Anolis EQUESTRIS Merrem.}

Merrem, Syst. Amphib., 1820, p. 5; Boulenger, loc. cit., p. 45; Barbour, loc. cit., p. 272.

Occurs not only in the woods, throughout the Island and also in orchards, especially of mango trees. Nowhere abundant.

\section{ANOLIS ANGUSTICEPS Hallowell.}

Hallowell, Proc. Acad. nat. sci. Phila., 1856, p. 228; Barbour, loc. cit., p. 292.

A rare woodland species. The type came from Cienfuegos; and was unique until the species was rediscovered near Cienfuegos; found also in the Sierra de Guane and in Havana Province.

\section{ANolis isolepis Cope.}

Cope, Proc. Acad. nat: sci. Phila., 1861, p. 214; Boulenger, loc. cit, p. 46; Barbour, loc. cit., p. 284.

A rare forest species confined to eastern Cuba where it replaces $A$. angusticeps.

27. Anolis lucius Duméril \& Bibron.

Duméril et Bibron, Erp. gén., 4, 1837, p. 105; Boulenger, loc. cit., p. 45 (pars); Barbour, loc. cit., p. 284.

Common upon limestone cliffs and crags of Matanzas Province and eastward to central Camaguey. 


\section{Anolis argenteolus Cope.}

Cope, Proc. Acad. nat. sci. Phila,, 1861, p. 213; Barbour, loc. cit., p. 285.

Eastern Cuba, almost always found on or near limestone rocks replacing the preceding.

29. Anolis sagrei Duméril \& Bibron.

Duméril et Bibron, Erp. gén., 1837, 4, p. 149; Barbour, loc. cit., p. 286.

The most common lizard in Cuba. Found in shrubs, on fences, and in gardens throughout the Island. A species characteristic of the cleared and open lowlands. Found also in Jamaica where it is rare and local (Kingston); it is probably introduced.

\section{Anolis GReYI Barbour.}

Barbour, loc. cit., p. 287.

Known only from the type-series taken in the garden of the Camaguey Hotel at Camaguey. Possibly found also in the Sierra de Cubitas.

\section{ANolis bremeri Barbour.}

Barbour, loc. eit., p. 288.

Type only known. It was taken on a thatched roof not far from Herradura, Cuba.

\section{Anolis loysiana (Cocteau).}

Cocteau, L'institute, 31 Aug., 1836, sec. 1, 4, p. 287; Boulenger, loc. cit., p. 42 (pars); Barbour, loc. cit., p. 290.

Found throughout the Island, but nowhere common.

\section{Anolis argillaceus Cope.}

Cope, l'roc. Acad. nat. sci. Phila., 1862, p. 176; Barbour, loc. cit., p. 291

Known from a few specimens, all taken in Oriente.

\section{Anolis spectrum Peters.}

Peters, Monatsb. Akad. wiss. Berlin, 1863, p. 136; Boulenger, loc. cit., p. 69; Barbour, loc. cit., p. 291.

This lizard has only been found by Gundlach who took it near Matanzas and Cardenas. Possibly synonymous with A. alutaceus. 


\section{Anolis cyanopleurus Cope.}

Cope, Proc. Acad. nat. sci. Phila., 1861, p. 211; Boulenger, loc. cit., p. 71; Barbour, loc. cit., p. 292.

First found by Wright at Monte Verde. It has since been found only by Gundlach in the Sierra Maestra and in the central part of the Island.- The type has apparently been lost; $;^{1}$ the junior author rediscovered the species at the type-locality in 1918.

\section{Anolis alutaceus Cope.}

Cope, Proc. Acad. nat. sci. Phila., 1861, p. 212; Boulenger, loc. cit., p. 71; Barbour, loc. cit., p. 292.

Not an uncommon species but one very difficult to see and capture. Found in the forests of the Sierra Maestra, of the mountains about Guantanamo and in the Provinces of Santa Clara, Matanzas, and Havana.

\section{ANolis Homolechis (Cope).}

Cope, Proc. Acad. nat. sci. Phila., 1861, p. 169; Boulenger, loc. cit., p. 28; Barbour, loc. cit., p. 274.

A not uncommon woodland species found throughout the Island. Conspicuous because of its pure white dewlap.

38. ANolis rubribarbus, sp. nov.

A new species recently discovered near Cabo Maisi.

39. ANOLiS QUADRIOCELLifER, sp. nov.

A new species known only from the Ensenada de Cajón, extreme western Cuba.

40. Anolis allogus, sp. nov.

A new species common in the forests of Oriente.

41. Anolis mestrei Barbour \& Ramsden.

I3arbour and liamsden, Y'roc. Biol. soc. Wash., 1916, 29, p. 19.

A rather obscure species known from various localities mostly in Pinar del Rio Province.

'This type U. S. N. M. 5,737 has been found recently. Thomas Barbour, May, 1919. 


\section{ANolis porcatus Gray.}

Gray, Ann. mag. nat. hist., 1810, 5, p. 112; Barbour, loc. cit., p. 293.

A very common species, usually found in parks and gardens, especially abundant upon Cacti, agaves, and other yuccaceous plants.

\section{Norops ophiolepis (Cope).}

Cope, Proc. Acud. nat. sci. Phila., 1831, p. 211 ; Boulenger, loc. cit., p. 26; Barbour, loc. cit., p. 296.

A not uncommon species in open grassy fields and plains. It lives upon the ground, over the whole Island.

\section{Cyclura macleayi Gray.}

Gray, Cat. lizards Brit. mus, 1815, p. 190; Cocteau, Sagra's Hist. Cuba. Rept., 1838, p. 96, pl. 6; Barbour, loc. cit., p. 297.

Rare upon the mainland of Cuba itself, but not yet so uncommon among the cays off the coast, especially near Manzanillo.

\section{Leiocephalus carinatus Gray.}

Gray, Philos, mag., 1S27, 2, p. 208; Boulenger, loc. cit., p. 165; Barbour, loc. cit., p. 300.

Common about beaches and sea-cliffs. A species characteristic of the area . of the sea-shore plant association.

\section{Leiocephalus (cubensis) Gray.}

Gray, Ann. mag. nat. hist., 1810, 5, p. 110.

L. vittatus Boulenger, loc. cit., p. 163; Barbour, loc. cit., p. 300.

A widespread and common species. Abundant in "guarda rayas" of the cane-fields and in open plains all over the Island.

\section{Leiocephalus raviceps Cope.}

Cope, 1'roc, Acad. nat. sci. Phila., 1862, p. 183.

A species known from the original specimens only. Perhaps not Cuban.

\section{Leiocephalus macropus Cope.}

Cope, Proc. Acad. nat. sci. Phila., 1862, p. 181; Boulenger, loc. cit., p. 163; Barbour, loc. cit., p. 301.

Apparently confined to the Province of Oriente and to be nowhere abundant. 


\section{Celestus de la sagra (Cocteau).}

Cocteau, Sagra's Hist. Cuba. Rept., 1838, p. 180, pl. 20; Boulenger, loc. cit., p. 293.

Found throughout the Island, but extremely rare everywhere.

50. Cricolepis typica (Gundlach \& Peters).

Gundlach und Peters, Monatsb. Akad. wiss. Berlin, 1863, p. 362, pl. -, fig. 1-6; Boulenger, loc. cit., p. 329 ; Barbour, loc. cit., p. 307.

Known only from a restricted area about Cabo Cruz, and Belig, a few miles away.

\section{Amerva Auberi Cocteau.}

Cocteau, Sagra's Hist. Cuba. Rept.,!'1843, p. 74, pl. 6; Boulenger, loc. cit., p. 356; Barbour, loc. cit., p. 309.

Found in open sunlit places throughout the Island. It is, of course, met with only upon the ground and is not rare.

\section{Cadea Blanoides Stejneger.}

Stejneger, Proc. Biol. soc. Wash., 1916, 29, p. 85.

Amphisbaena punctata Boulenger, loc. cit., p. 450, pl. 23, fig. 3; Barbour, loc. cit., p. 317.

Gundlach knew little of this and the following species; he says nothing of their distribution. The only specimens which we have seen came from near San Diego de los Baños, near Herradura and Caimito del Guayabal.

\section{Amphisbaena cubana Peters.}

Peters, Monatsb. Akad. wiss. Berlin, 1878, p. 780, pl. -, fig. 4; Boulenger, loc. cit., p. 446; Barbour, loc. cit., p. 317.

Peters described this species from specimens sent to him by Gundlach who could not recall where he took them. The only specimens which we have seen with definite data came from central "Soledad" near Cienfuegos, from San Carlos, Guantanamo, La Demajagua, in Oriente, from Havana and the Ensenada de Cochinos.

Reptilia: Squamata, Serpentes.

54. Typhlops lumbricalis (Linné).

Linné, Syst. nat. ed. 10, 1758, 1, p. 228; Stejneger, Rept. U. S. N. M. for 1902, 1904, p. 684; Barbour, loc. cit., p. 322 .

A common species found everywhere under stones and decaying vegetable 
rubbish. It occurs also in Jamaica, Haiti, and Porto Rico, as well as on most of the Lesser Antilles and the Bahamas.

\section{Epicrates angulifer Bibron.}

Bibron, S'agra's Hist. Cuba. Rept., 1843, p. 215, pl. 25; Boulenger, Cat. snakes I3rit. mus., 1893, 1, p. 96; Barbour, loc. cit., p. 326.

A common and widespread species. Wholly confined to Cuba and the surrounding cays.

\section{Tropidophis melanurus (Schlegel).}

Schlegel, Essai phys. serp., 1837, 2, p. 399; Boulenger, loc. cit., p. 111; Barbour, loc. cit., p. 327.

Widespread throughout the Island to which it is confined.

\section{Tropidophis pardalis (Gundlach).}

Gundlach, Archiv. naturg., 1840, 1, p. 359; Boulenger, loc. cit., p. 113; Barbour, loc. cit., p. 325.

A species which appears to be more common in the Bahamas than in Cuba.

\section{Tropidophis maculatus (Bibron).}

Bibron, Sagra's Hist. Cuba. Rept., 1843, p. 212, pl. 24; Boulenger, loc. cit., p. 112; Barbour, loc. cit., p. 328.

Not uncommon throughout Cuba. What is probably the same species occurs also in Haiti, Jamaica, and Navassa.

59. Tropidophis semicinctus (Gundlach \& Peters).

Gundlach und l'eters, Monatsb. Acad. wiss. Berlin, 1864, p. 388; Boulenger, loc. cit., p. 113; Barbour, loc. cit., p. 329.

A very rare species which occurs irregularly over the whole Island.

60. Tretanorhinus variabilis Duméril \& Bibron.

Duméril et Bibron, Erp. gén., 1854, 7, p. 349, pl. 80, fig. 4; Boulenger, loc. cit., p. 282; Barbour, loc. cit., p. 330 .

Nocturnal, hence seldom seen. Strictly aquatic and found among rocks and drift material. Confined to Cuba.

\section{Alsophis ANGULifer (Bibron).}

I3ibron, Sagra's Hist. Cuba. Rept., 1813, p. 222, pl. 27; Boulenger, loc. cit., 1891, 2, p. 120 (pars); Barbour, loc. cit., p. 333.

The most common and generally distributed snake in Cuba. 


\section{Leimadophis ANDREAE (Reinhardt \& Lütken).}

Reinhardt and Lütken, Vid. meedel. nat foren KKjobenh. for 1862, 1863, p. 214; Boulenger, loc. cit., p. 140; Barbour, loc. cit., p. 338 .

Common throughout the whole Island.

63. ARRHYTon taEniatum Günther.

Günther, Cat. snakes Brit. mus., 1858, p. 244; Boulenger, loc. cit., p. 252; Barbour, loc. cit., p. 341.

The few known specimens have been found at scattered localities through the Island.

64. Arrhyton vittatum (Gundlach \& Peters).

Gundlach und Peters, Monatsb. Acad. wiss. Berlin, 1861, p. 1002; Boulenger, loc. cit., p. 252; Barbour, loc. cit., p. 341 .

What has been said regarding the previous species applies to this one also.

65. ARrhyton Redimitum (Cope).

Cope, Proc. Acad. nat. sci. Phila., 1862, p. 81.

A small species of which nothing is known and which is very probably an abnormal phase of $A$. taeniatum.

Reptilia: Testudinata.

66. Pseudemys palustris (Gmelin).

Gmelin, Syst. nat., 1788, 1, p. 1041; Barbour, loc. cit., p. 344, (synonymy).

This tortoise occurs in ponds and streams throughout Cuba, and also in Jamaica, Haiti, and Porto Rico.

REPTILIA: LORICATA.

67. Crocodylus acutus Cuvier.

Cuvier, Ann. Mus, hist. nat., 1807, 10, p. 55, pl. 1, 2.

Found in the brackish creeks and estuaries in various parts of Cuba, the surrounding cays, as well as in Florida, Jamaica, Haiti, Mexico, Central America, and the coast of Equador.

68. Crocodylus rhombifer Cuvier.

Cuvier, Ann. Mus. hist. nat., 1807, 10, p. 51; Boulenger, Cat. chelonians Brit. mus., 1889, p. 287; Barbour, loc. cit., p. 345.

Confined to the Cienaga de Zapata, Cuba, and the Cienaga de Lanier, Island of Pines. Not uncommon in these areas. 


\section{SYSTEMATIC ACCOUNT OF THE SPECIES.}

Keys.

The following series of keys has been prepared to facilitate identifications, but they cannot be expected to prove serviceable invariably. The young of many species differ greatly from the adults, and, moreover, the adults often vary inter se in a surprising degree. With Anolis especially the difficulty of exact diagnosis is very great. 'The keys therefore should be used in connection with the detailed descriptions; or, when possible, comparatively with typical or authentically named specimens.

\section{AMPHIBIA: SALIENTIA.}

Key to the Genera.

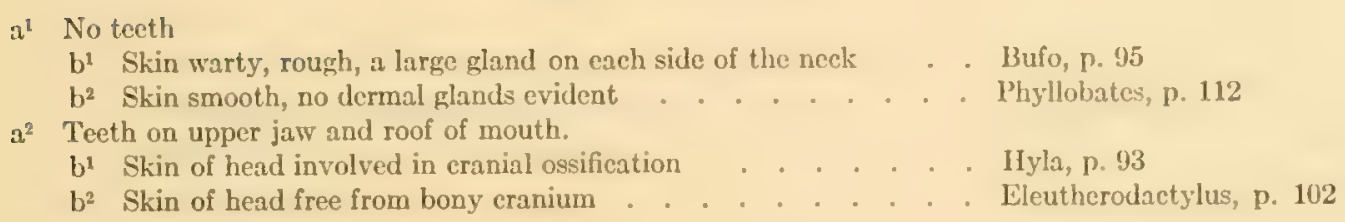

\section{HYLIDAE。}

\section{Hyla septentrionalis Boulenger.}

Plate 1, fig. 1.

\section{Rana; Rana platanera.}

Diagnosis:- A gray, light greenish or brownish tree frog which reaches a very large size. The skin of the head is completely involved in the cranial ossification and the surfaces of back, sides, and belly are covered with warts of varying size. Tips of fingers and toes with enormous sucking pads.

Description:-Adult M. C. Z. 3,713. Cuba: Pinar del Rio; Guane, March, 1915. Thomas Barbour.

Tongue broad, much broader than long, unemarginate; vomerine teeth in a single continuous series between the large choanae, the posterior border of this series being slightly behind the posterior margins of the choanae; nostrils 
near tip of snout and distance from eye slightly greater than its diameter; fingers with enormous dises, toes with similar dises and completely webbed; head broad (the breadth increasing with age, in young specimens the head is longer than broad, in adults the reverse is true); skin of head involved completely in the cranial ossification; posterior outline of casque openly emarginate (the degree of emargination varies greatly with age and in different specimens); snout rounded; loreal region oblique, concave; canthus rostralis strongly marked; crown distinctly concave (less concave or almost flat in halfgrown and young specimens); interorbital space nearly three times as broad as the upper eyelid; tympanum large and distinct, at least two thirds the diameter of the eye; the hind limb being adpressed to the body the tibiotarsal articulation reaches the eye; upper surfaces strongly tubercular, lower surfaces coarsely granular, a fold above the tympanum; male with external vocal sacs and blackish rugosities on the inner side of the first finger (during the nuptial season only).

Colour (in life):- Grayish varying to whitish, greenish or brownish, variously spotted and striped. Hinder side of thighs reticulated with black.

$\begin{array}{lr}\text { Dimensions: - Tip of snout to vent } & 90 \mathrm{~mm} . \\ \text { Width of head } & 35 \mathrm{~mm} . \\ \text { Diameter of eye } & 9.5 \mathrm{~mm} . \\ \text { Diameter of tympanum } & 7.5 \mathrm{~mm} \text {. } \\ \text { Fore limb from axilla } & 54 \mathrm{~mm} . \\ \text { Hind limb from vent } & 145 \mathrm{~mm} . \\ \text { Vent to heel } & 88 \mathrm{~mm} .\end{array}$

The big tree frog is found throughout the entire Island, and is most abundant everywhere in the groves of banana trees in the lowlands. It is often found about the stone cisterns so widely used in Cuba, and its call, like the noise made when a rope is drawn through an unoiled block, is frequently heard on rainy evenings and even in the day time during a shower. The species is rare or absent in the deep forest, being found, however, about cultivated plantations at a considerable altitude.

Gundlach and other naturalists believed that there were three species of Hyla found in Cuba, but the type of Hyla wrightii Cope, which has been examined in the U. S. N. M., proves to be a synonym of Hyla septentrionalis. The same is beyond doubt true of Hyla insulsa Cope, although the type has been lost. 


\section{BUFONIDAE.}

Key to the Species of Bufo.

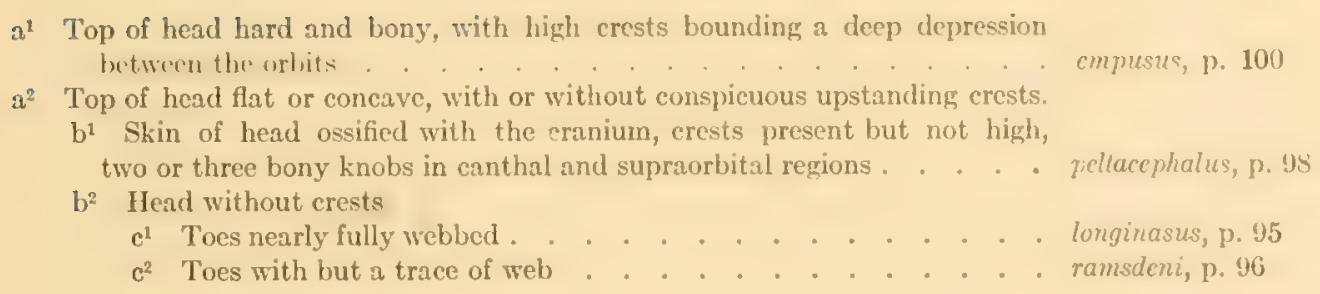

\section{Bufo Longinasus Stejneger.}

Plate 13, fig. 1.

Palmer's Toad.

Diagnosis:- A small toad having no cranial bony ridges; first finger shortel' than second; toes nearly fully webbed; skin smooth, pustulous, but without asperities; snout conical, projecting, pointed, with the nostrils near the tip, parotoids enormous, their length almost equalling their distance from the groin. Description:- TYPe. Adult of U. S. N. M. 27,419. Cuba: Pinar del Rio City, near El Guamá, 9 March, 1900. William Palmer and J. H. Riley.

"Head and body depressed, nearly flat above; snout concave along median line, conical, projecting, pointed; nostrils near the tip of snout and close together; canthus rostralis rounded; interorbital width much greater than width of upper eyelid; tympanum indistinct, about half the diameter of the eye; first finger shorter than second, with a pad of dark brown nuptial asperities on top and side of basal portion; tips of fingers and toes slightly swollen; toes nearly fully webbed; subarticular tubercles well developed, double; inner metatarsal tubercle moderate, not prominent, outer conical; a tarsal fold, the distal end of which resembles the inner metatarsal tubercle; tibio-tarsal articulation of hind leg extended forward along the side of the body, reaches halfway between insertion of fore leg and tympanum; skin above smooth with irregular smooth, distinctly pitted pustules separated posteriorly and on sides by anastomosing furrows; parotoids enormous, their length almost equaling their distance from the groin, flat, descending on sides below the level of the tympanum, deeply pitted; throat longitudinally wrinkled on breast and belly, and underside of femurs coarsely granulated. Color (in alcohol) above, dark purplish maroon; underneath, including the upper lip, a narrow space above the insertion of the arm, and the internal half of the upper side of hands and feet white; a few dark purplish brown specks on lips, chest, and tibia and a longitudinal mark of the same color in front of insertion of fore legs. 'l'otal length, tip of snout to vent, $25.5 \mathrm{~mm}$... . Length of hind limb from vent to tip of longest toe $32 \mathrm{~mm} . "$ Stejneger, Proc. U. S. N. M., 1905, 28, p. 765-767. 
So far this species is known from the type, which was captured sitting upon a mossy stone in a small brook, at dusk on a March evening in 1900. Mr. Palmer was kind enough to give a minute description of just how he found the spot where this treasure was caught. A careful search at that locality failed to reveal the species, and it is probably one of those curious forms which make but a periodical appearance and remain hidden during long intervals. Judging from what we know of its ally, Bufo ramsdeni Barbour, from the mountains near Guantanamo, it is probable that the species is extremely local in its distribution. For the benefit of those who may collect in Cuba, and have an opportunity to search again at the type-locality for this species, it may be stated that El Guamá, with the accent strongly on the last syllable, is not a town or village, as would appear from the many labels of the Palmer and Riley collection, and the name is not to be found on any map of Cuba which we have consulted. El Guamá is named from a useful tree, from the inner bast of which a strong rope may be readily twisted. A few miles to the north of the city of Pinar del Rio, one finds a stream by this name, which increases in size and finally becomes Rio Guamá, which flows through the city of Pinar del Rio itself, and runs southward, emptying into the Gulf of Batabanó at Coloma. On the bank of the upper reaches of the stream there is a small farm and a country store, which, as is common with such properties in Cuba, bear a distinctive name. This is El Guamá. According to a recent rumor the finca has been abandoned, and it is not unlikely that the store may move, in which case the type-locality of Bufo longinasus will be very difficult to identify.

\section{Bufo ramsdeni Barbour.}

Plate 1, fig. 2.

Ramsden's Toad.

Diagnosis:- A small toad having no cranial ridges; first finger shorter than second which is very long; toes with but a trace of web; skin smooth with scattered asperities; snout conical, projecting, pointed, with the nostrils near the tip; parotoids very large.

Description:- Trpe. Adult of M. C. Z. 3,212. Cuba: Guantanamo, Monte Libano, Los Hondones. C. T. Ramsden.

Head and body depressed; snout concave along median line, projected and rather pointed; canthus rostralis rounded; interorbital space much wider 
than upper eyelid; tympanum scarcely visible; first finger shorter than second; tips of fingers and toes not dilated and hardly swollen at all; fingers slender, longer than in B. longinasus; toes slightly webbed; subarticular tubereles large, single; both metatarsal tubercles well developed; a tarsal fold; tibiotarsal articulation of adpressed hind limb reaches midway between insertion of fore limb and tympanic region; skin itself smooth, with small wrinkles and many tubercles arranged in more or less regular longitudinal series; parotoids greatly developed as in Bufo longinasus.

Colour (in alcohol):- Above almost black, a conspicuous light stripe from snout to vent, this stripe is extended laterally on the eyelids and thus widens to a rhomb-like figure on the head. The light stripe is bordered on each side by a narrow band of deep velvety black. Below, the throat is mahogany-brown, the fore part of the chest and angles of the jaws deep brown; the belly is white, profusely spotted and streaked with dark brown, as are also the lips and upper surfaces of the limbs.

$\begin{array}{cr}\text { Dimensions: - Tip of snout to vent } & 21 . \mathrm{mm} . \\ \text { Width of head } & 9 . \mathrm{mm} . \\ \text { Fore limb from axilla } & 11.2 \mathrm{~mm} . \\ \text { Hind limb from vent } & 25.2 \mathrm{~mm} . \\ \text { Vent to heel } & 14.5 \mathrm{~mm} .\end{array}$

When Bufo ramsdeni was described only the type, a female, was known, while of $B$. longinasus the type also was unique and a male. There was naturally on our part a slight feeling that possibly these might represent the opposite sexes of a species in which the sexual dimorphism was much greater than usual. Happily we can now state definitely that this is not the case, since careful collecting at Los Hondones has revealed three other specimens, an adult and two young males. The adult pair are of the same size, about $30-35 \mathrm{~mm}$. from snout to vent. The male agrees very closely with the female described in all essential characters, except colouration. This is quite different, being uniform chocolate on all the upper surfaces, while the ventral surfaces are like the female.

All of these examples, the only ones found, were caught in a deep forest, in a very wet area on the road from Guantanamo to Los Hondones, and some fifteen miles north of Guantanamo. Here the road, only about five feet wide, passes between two large moss covered boulders called "Las Comadres." On each oceasion when toads were found it had been raining heavily and the ground 
was temporarily flooded. They appear during the heavy showers, and for a short while afterwards remain hopping about with Eleutherodactylus dimidiatus. The fact that careful collecting in similar stations on the other mountains about Guantanamo, as well as in very many different localities in all parts of Cuba, makes it seem probable that this species may be represented by this small isolated colony at Los Hondones alone. Its ally, and it seems to have no other very close relative anywhere, occurs far away, near Pinar del Rio. These two groups probably represent the remnants, differentiated during their long isolation, of some style of Bufo which once ranged more widely over the island. For some reason unable to survive, perhaps because of coming into competition with more successful conquerors or from being specially preyed upon by natural enemies, it is now on the very verge of disappearance. Naturalists of the present day are witnesses to this phenomenon quite often in the West Indies; we need only recall the case of Cricolepis and Stejneger's remarkable account of Bufo lemur in Porto Rico (Ann. rept. U. S. N. M. for 1902, 1904, p. 573), or Peters's finding Bufo turpis in Virgin Gorda ( $c f$. Barbour, Proc. Biol. soc. Wash., 1917, 30, p. 102). Among mammals the status of Solenodon cubanus presents a perfectly comparable example.

\section{Bufo peltacephalus Tschudi.}

Plate 13, fig. 2.

Sapo; Sapo comun.

Diagnosis: - The largest Antillean toad may be distinguished at once from the three other Cuban species by the low and widely separated supraorbital crests and by the fact that the canthal crest (from eye to nostril) ends in one or more very prominent knobs.

Description:-Adult M. C. Z. 3,724. Cuba: Pinar del Rio; Guane, March, 1915. Thomas Barbour.

Skin of head completely involved in cranial ossification; crown with ridges which are not especially prominent, although well defined; a canthal not confluent with the supraorbital and ending in one or more prominent knobs; a supraorbital also ending in a knob anteriorly, and forming a right angle with the postorbital ridge; a prominent orbitotympanic ridge; snout short, bluntly rounded; interorbital space very broad, almost twice as broad as an upper eyelid; tympanum distinct about half the diameter of the eye; first finger 
about equal to second; toes half webbed; subarticular tubercles single; two moderate metatarsal tubereles; a short tarsal fold; the hind limb being carried forward along the body the tarsometatarsal articulation reaches the angle of the mouth; upper surfaces with small warts of very even size; parotoids prominent, elliptical, obliquely placed; male with a subgular vocal sac.

Colour (in life):- Uniform brown varying, darker or lighter as the case may be, to a dirty yellow with brown blotches, the lower surfaces uniformly pale.
Dimensions: - Tip of snout to vent
$111 \mathrm{~mm}$.
Tip of snout to posterior edge of tympanum
$36 \mathrm{~mm}$.
Greatest width of head
$48.5 \mathrm{~mm}$.
Fore leg from axilla
$53 \mathrm{~mm}$.
Hind leg from vent
$130 \mathrm{~mm}$.

The big common Sapo of Cuba is found very widely distributed throughout the Island. It is, however, by no means invariably possible to secure specimens. The species is strictly nocturnal and is irregular in its appearance. On hillsides where there are scattered rocks and where there is some shade Bufo peltacephalus is often abundant; also about country towns, living in the mouths of the drains of tile made to carry off the rush of water which falls during the torrential showers of the rainy season. As many as five or six of these toads have been found together under the trunk of a fallen Barragona Palm where they had excavated a large cavity for themselves. While they do not burrow like Bufo empusus they often prepare a large chamber with a tunnel entrance beneath the stone or $\log$ where they may have taken up abode. Its voice, frequently heard all night after a shower of warm rain, is loud and sounds like an ill-tuned guitar. When one approaches the toad it hushes at once and will not sing again while one remains close at hand. Of its breeding habits little is known; the young are common and may be found during most of the year. Gundlach in his Erpetologia Cubana (1880, p. 83) gives a simple and quite fascinating bit of folk lore. He says that the peasants believe that a toad may cure erysipelas as follows:- a toad is rubbed over the affected regions of a victim of erysipelas and then the toad is to be carried off and hung up. As the toad dies the disease will disappear; should the toad escape the result is not so sure. We might observe by way of explanation that hanged toads take a long time to die and in Cuba victims of erysipelas usually recover. This belief with many others persists to the present time. As with 
so many of the larger species of Bufo the white discharge from the parotoid glands is copious and powerful, and experience has taught both men and dogs of its highly venomous nature.

The young are found in bands along the Guarda Rayas of the Guantanamo cane fields in the spring, especially if it has been a rainy one. They develop in the drainage ditches of the cane-fields and are beautifully marked with splashes of rich dark green on the brown.

There is a belief among the country folk, in many parts of Cuba, that the big toad cannot live in the woods where the Cuban Solitaire (Myadestes elizabeth (Lembeye)) is found. For upon hearing the heavenly flute-like strains of these glorious peerless songsters, the toads try to imitate them with their guttural croakings so strenuously that their attempts end fatally. As a matter of fact, however, the Bufo is not found in the deep woods about Guantanamo where the Myadestes abounds, although it occurs plentifully about the Sierra de Paso Real, Sierra de Guane, and in the valley of Luis Lazo where Solitaires are very often to be heard; higher up to be sure than the toads, but well within hearing.

\section{Bufo empusus (Cope).}

Plate 1, fig. 3.

Sapo de concha; Guasábalo.

Diagnosis:- A rather small toad living in burrows, in large colonies, having the whole head extremely hard and bony, the cephalic crests very prominent and the lip margin hard and modified for digging.

Description:-Adult M. C. Z. 2,833. Cuba: Pinar del Rio; Herradura, March, 1910. Thomas Barbour.

Top of head bony, with enormous crests, enclosing a deep hollow between the orbits, the canthal crests meet anterior to the nostrils and form a $\mathrm{V}$, then merge with the enormous supraorbital crests; the anteorbital crest is likewise prominent, the supratympanic crest is far less prominent and ends in a small knob; two crests on the occiput converge but do not meet, they are continuous with supraorbitals and are composed of high, flat tubercles partly confluent; snout rather depressed, the labial margin produced into a hard flange extending around the snout; tympanum elliptical, erect, its greatest diameter scarcely one half that of the eye; parotoid gland small, long, simply the anterior elabora- 
tion of a lateral series of enlarged warts; first fingers slightly shorter than second; toes less than half webbed; subarticular tubercles single; two very well-developed metatarsal tubercles; a tarsal fold; back and sides covered with numerous warts, varying greatly in size, some of the lateral warts slightly spinose, others smooth; lower surface with smaller warts; upper surface of hands and feet almost smooth.

Colour (in life):- Variegated brown with dark, almost black streaks and spots; a dirty yellow streak on the parotoid and along the lateral series of enlarged warts; elsewhere on the sides scattered spots of dull yellow; lower surfaces paler yellowish.

\begin{tabular}{lr} 
Dimensions: - Tip of snout to vent & $69 \mathrm{~mm}$. \\
& Tip of snout to posterior edge of tympanum \\
Greatest width of head & $20 \mathrm{~mm}$. \\
Fore leg from axilla & $24.5 \mathrm{~mm}$. \\
Hind leg from vent & $33 \mathrm{~mm}$. \\
\hline
\end{tabular}

Bufo empusus belongs to a small and very peculiar group of toads. It is most closely related to Bufo gutturosus Latreille from Haiti, less closely to Bufo lemur Cope from Porto Rico and Bufo turpis Barbour of Virgin Gorda. The species from Haiti and Porto Rico were long confounded with each other but are really very distinct. Bufo lemur reaches a much greater size than the Haitian Sapo de concha, which in turn is larger than $B$. empusus. This species has not been observed in Oriente and it is apparently entirely confined to western Cuba where terrain suitable to its peculiar habits may be found. The related toads of Haiti and Porto Rico have apparently more or less the habits usual to species of Bufo. The following account records the discovery of a colony of the toads near Herradura in the flat plains region of eastern Pinar del Rio Province. The great number of adults found in the colony were remarkably uniform in size, the measurements given being typical.

"Gundlach found this species, so rare in collections, rather common locally in the Cienaga de 'Zapata, in the jurisdiction of Colon, in the savannas near Los Ciegos, and Los Palacios in the Vuelto Abajo region of the Province of Pinar del Rio. I was able to obtain a splendid series in some plains about five miles northeast of Herradura, also in the Province of Pinar del Rio. I should never have learned of their existence had it not been for the aid given me by an intelligent young Cuban, Sr. Lucio Alfonso. In response to my inquiry: regarding the occurrence of the "Sapo de Concha," he took me to an upland clayey pasture near by, which had recently been burned over. Scattered thickly over this whole area were the mouths of a great number of small burrows. These were evidently of two sorts, for the openings of some were carefully rimmed with smoothly patted clay, while the others were 
rough and looked unfinished. Those with the rims each contained a Bufo empusus. The tube-like burrow was perfectly cylindrical and from seven to ten inches deep. The toad which always looked larger than the diameter of the burrow, was to be found in a small chamber at the bottom, its curious hornlike, shelly, head forming an operculum which closed the burrow accurately. To accomplish this closing most advantageously, the toad was sometimes found resting on its side or back. The small individuals were frequently observed near the surface, their little heads just filling the mouth of the tubes. Only one or two adults were observed near the surface. The other burrows spoken of were inhabited by Tarantulas, which were excessively common.

Gundlach says, and he is confirmed by what the country folk told me, that these toads come forth to sing in unison on warm nights after a rain. There is no apparent rule to guide their appearance and they are not heard during many apparently favorable nights. The people told me that they had never met them outside their burrows, probably because they had not visited this particular field by night. From what I have heard, I am sure this species always occurs in these colonies in areas where the soil is suitable for making their burrows." Barbour, Mem. M. C. 'Z., 1914, 44, p. 242, 243.

\section{LEPTODACTYLIDAE.}

Key to the Species of Eleutherodactylus.

$a^{1}$ Belly coarsely granular

$\mathrm{b}^{\mathrm{l}}$ Toes with large terminal dilatations . . . . . . . . . . . . auriculatus, p. 109

$\mathrm{b}^{2}$ Toes without large terminal dilatations ........... varians, p. 108

$a^{2}$ Belly smooth, wholly or at least in the centre.

$c^{1}$ A distinct dorsolateral fold.

$\mathrm{d}^{1}$ Skin of back finely warty . . . . . . . . . . cuneatus, p. 105

$\mathrm{d}^{2}$ Skin of back smooth . . . . . . . . . . . . . dimidiatus, p. 104

$c^{2} \quad$ No dorsolateral fold.

$\mathrm{e}^{1} \quad$ Skin of back smooth, or finely granular . . . . . . ricordii, p. 102

$\mathrm{e}^{2} \quad$ Skin of back everywhere strongly plicate and warty - . plicatus, p. 107

\section{Eleutherodactylus Ricondi (Duméril \& Bibron).}

Plate 13, fig. 3-5.

\section{Ranita; Ventorilla; Campanilla.}

Diagnosis:- A small frog with granular margin and smooth midbelly area, a small tympanum and a very short soled foot. A ventral sucking disc is present and the tips of the fingers and toes are scarcely if at all dilated.

Description:-Adult M. C. Z. 2,838. Cuba: Havana, Botanical Gardens, February, 1910. Thomas Barbour.

Tongue large, oval, free and entire behind; vomerine teeth in two long curved, posteriorly converging series almost meeting on the median line and immediately behind the small, round choanae; head not wider than body; snout but very slightly declivous; nostril much nearer tip of snout than eye; 
interorbital space distinctly wider than upper eyelid; tympanum round, distinct but only about half, or a little less, than the diameter of the eye; its distance from the eye less than its own diameter; fingers without dises, the first and second equal in length; toes with almost no apical expansion, first toe much shorter than second; subarticular tubercles well developed, a few scattered tubercles upon the short soles; a well-developed inner and outer metatarsal tubercle; no tarsal fold; the hind limb being carried forward the tibiotarsal articulation reaches the posterior border of the eye; bent vertically to the axis of the body the heels fail to meet; skin above generally smooth but with a good many scattered small warts; throat and anterior aspects of thighs smooth; belly coarsely but not conspicuously granular about the margin, smooth in the centre, hinder aspect of thighs granular; a ventral discoidal fold.

Colour (in life):- Uniform dark brown flecked with white to ashy gray, marbled with darker. The variation in colour is almost limitless.

$\begin{array}{cr}\text { Dimensions: - Tip of snout to vent } & 24 \mathrm{~mm} . \\ \text { Width of head } & 8.5 \mathrm{~mm} \text {. } \\ \text { Diameter of eye } & 2.2 \mathrm{~mm} \text {. } \\ \text { Diameter of tympanum } & \text { about } 1 \mathrm{~mm} \text {. } \\ \text { Fore limb from axilla } & 15 \mathrm{~mm} \text {. } \\ \text { Hind limb from vent } & 34 \mathrm{~mm} \text {. } \\ \text { Vent to heel } & 18 \mathrm{~mm} \text {. }\end{array}$

The species was not very satisfactorily described by Duméril and Bibron, but nevertheless this is beyond doubt the one which they named. It has been found in many parts of Cuba, except in eastern Oriente, but seems to be most abundant in central and western Cuba. It is terrestrial, found under rocks, decaying vegetation, especially about the shores of sluggish brooks. Occasionally it reaches a large size, or rather we also refer to this species, but with some hesitation, a few very large examples mostly from the Province of Santa Clara. They measure nearly $40 \mathrm{~mm}$. from snout to vent. This is probably the most common species which calls at night; its voice like a tiny bell, is heard coming sometimes from thousands of hidden throats in the trash of the cane-fields, after a shower, from the woods and thickets and even from quiet spots in cultivated gardens. They are shy and stop singing at once if one approaches.

In the Botanical Garden at Havana this little frog is common as well as in the yards of the houses in many cities and towns. It seems to be the only species of the genus which has associated itself so closely with the habitations of man. 


\section{Eleutherodactylus dimidatus (Cope).}

Plate 13, fig. 6-8.

\section{Ranita; Ventorilla; Campanilla.}

Diagnosis:- A small woodland frog, having a faint dorsolateral fold and perfectly smooth skin on the back. There is almost always at least a trace of a light middorsal stripe, forking over the vent and passing down the back of each thigh. There is a dark stripe on the tympanic region and a black spot on each side near the sacral region.

Description:-Adult M. C. Z. 3,045. Cuba: Oriente; Jiguaní, Los Negros (Sierra Maestra Mts.), March, 1913. Thomas Barbour.

Tongue broad, oval, free and unnotched behind; vomerine teeth in two long curved series a short distance behind the choanae, the series separated by a very narrow median interspace, the series extend to the line of the maxillae; nostrils near tip of snout, their distance from eye equal to its diameter; upper eyelid distinctly narrower than interorbital space; tympanum round, rather large, about equal to two thirds of the diameter of the orbit; fingers without discs, first finger very slightly longer than second; toes with very small scarcely discernible dises; tip of first toe not quite reaching base of second; two very inconspicuous metatarsal tubercles; soles smooth; a faintly indicated tarsal fold; the bent limbs being pressed along the side, knee and elbow overlap slightly; with the adpressed hind limb the tibiotarsal articulation extends slightly beyond the tip of the snout; the hind limbs being placed vertically to the axis of the body the heels overlap considerably; skin above perfectly smooth, a very fine glandular dorsolateral fold along each side; skin of throat, belly, and limbs smooth; belly without modified discoidal area.

Colour (in life):- Varying shades of slate or gray. Hind limbs lighter, anterior aspects of thighs often yellowish or with a faint tinge of pink. A broad dark stripe extends along the snout over the tympanic area to behind the insertion of the fore limb. Upon each side on the lumbar or sacral region there is a conspicuous black spot. A light middorsal line which forks above the vent and passes along the hinder side of each thigh is very characteristic of the species and is almost invariably present.

$\begin{array}{cc}\text { Dimensions:- Tip of snout to vent } & 32 \mathrm{~mm} . \\ \text { Width of head } & 11 \mathrm{~mm} . \\ \text { Diameter of eye } & 3 \mathrm{~mm} .\end{array}$


Diameter of tympanum

Fore leg from axilla

Hind leg from vent

Vent to heel
$2 \mathrm{~mm}$.

$15 \mathrm{~mm}$.

$46 \mathrm{~mm}$.

$5.5 \mathrm{~mm}$.

This beautiful little frog is usually found in damp woodlands. It was first described from eastern Cuba (doubtless Monte Verde) having been collected by Charles Wright. We believe that it is confined to the Province of Oriente, for it has been found at Monte Libano and Yateras near Guantanamo (Ramsden) at Cayo del Rey near Alto Cedro (Torre) and at several localities in the Sierra Maestra (Barbour). As we have indicated, this species until recently appeared rare and is usually only found under stones or decaying vegetable matter along the banks of some mountain stream. Recent observations of the junior author (Ramsden) show that this frog is really not rare in the mountain ranges to the north of Guantanamo. Indeed one finds it in abundance and in all sizes, at a place called San Felipe on Monte Toro in deep forest when the "Palma Juta" grows. Here the palm is called "Palma juta" and the places where it grows abundantly are known locally as "Jutales."

\section{Eleutherodactylus cuneatus (Cope).}

Plate 13, fig. 9-11.

Ranita.

Diagnosis:- A beautiful little frog usually gray with a white lateral stripe, dark spots in the groin and bright pink thighs. The skin of the belly is modified into a disc-like organ of adhesion. There is a prominent glandular dorsolateral fold and the skin of the back is rough.

Description:- Adult M. C. Z. 3,882. Cuba: Oriente; La Patana near Baracoa. V. J. Rodriguez.

Tongue rather broad, oval, very slightly nicked behind; vomerine teeth in two long curved series posterior but adjacent to the choanae, extending laterally to above the maxillae and separated mesially by a very narrow interspace; nostril almost at tip of snout, its distance from the eye about equalling its diameter; upper eyelid much narrower than interorbital space, tympanum rather large, round, with a prominent glandular supratympanic fold, its diameter rather less than two thirds the diameter of the eye, its distance from the eye 
equal to about one half its diameter; fingers without.discs, first finger equalling second in length; toes without dises; tip of first toe reaching well beyond the large second subarticular tubercle of the second toe; two well-developed metatarsal tubercles, the inner the larger; soles with many small scattered tubercles, subarticular tubercles large; no tarsal fold; the bent limb being adpressed along the side, knee and elbow overlap considerably; the hind limb being adpressed the tibiotarsal articulation reaches about two thirds of the distance between eye and nostril; the hind limbs being placed vertically to the axis of the body, the heels overlap considerably; skin above rather coarsely granular, a fine middorsal glandular line and a well-developed glandular dorsolateral fold; throat and belly smooth; posterior aspect of thighs rather coarsely granular; belly with a strongly marked discoidal fold.

Colour (in life):- Varied brown with darker blotches, usually a dark cross-bar between the eyes and along the canthal and tympanic regiorıs. Usually a conspicuous lumbar spot and two broad, pale dorsolateral stripes. The anterior aspect of thighs and the posterior aspects of the tibial regions are usually bright coral-pink, especially brilliant in the males.

$\begin{array}{lr}\text { Dimensions: - Tip of snout to vent } & 41 \mathrm{~mm} . \\ \text { Width of head } & 19 \mathrm{~mm} . \\ \text { Diameter of eye } & 5 \mathrm{~mm} . \\ \text { Diameter of tympanum } & 3.25 \mathrm{~mm} . \\ \text { Fore limb from axilla } & 23.5 \mathrm{~mm} . \\ \text { Hind limb from vent } & .63 \mathrm{~mm} . \\ \text { Vent to heel } & 37 \mathrm{~mm} .\end{array}$

Eleutherodactylus cuneatus is the largest member of its genus found in Cuba; it is also by no means common although it ranges widely. Like $E$. dimidiatus, it was first described from Wright's collection made in eastern Oriente; it occurs also on Monte Libano and at Bayate (Ramsden), near Santiago (Wirt Robinson) and in the Sierra Maestra, at Soledad near Cienfuegos and in the Sierra de Guane in western Pinar del Rio (Barbour). The specimen described and measured from near Baracoa is the largest we have ever seen. It is a woodland species and one which appears to be found mostly in the damper mountainous forests. 


\section{Eleutherodactylus Plicatus Barbour.}

Plate 6, fig. 1.

Ventorilla or Ranita.

Diagnosis:- A small terrestrial frog with the dorsal surface strongly plicate or rugose; its colour is uniform olive-brown above with the lower surfaces and especially the thighs pink.

Description:- Type. Adult M. C. Z. 3,056. Cuba: Guantanamo, Monte Libano, La Union, 23 March, 1913. C. T. Ramsden.

Tongue medium, oval, entire behind; vomerine teeth in two long series which converge posteriorly and almost meet at median line, extending laterally to but very little beyond the choanae which are situated nearer the median line than in other species; head broad and rounded; snout only slightly declivous; nostril much nearer the tip of the snout than eye; upper eyelids slightly less wide than interorbital space; tympanum medium size and round, about one half the diameter of the eye; its distance from the latter equal to its own diameter; fingers with exceedingly small dises, the first and second fingers much shorter than second; subarticular tubercles well developed; no marked plantar tubercles; a rather small inner and outer metatarsal tubercle; a feebly developed tarsal fold which in the type and paratype may be due to shrinkage; hind limb being bent forward along the body the heel reaches well beyond the tip of snout, bent vertically to the axis of the body the heels overlap considerably; skin above extremely rugose and plicate; throat, chest, and anterior aspect of thighs perfectly smooth, belly and posterior femoral aspects finely granular.

Colour (in fresh specimen):- Almost uniform dark olive-brown above, the lower surfaces pinkish almost roseate; the fronts of the thighs a fine brilliant pink, throat with a few dark dots.

$\begin{array}{lr}\text { Dimensions: - Tip of snout to vent } & 22 \mathrm{~mm} . \\ \text { Width of head } & 10 \mathrm{~mm} . \\ \text { Diameter of eye } & 3 \mathrm{~mm} . \\ \text { Diameter of tympanum } & 1.5 \mathrm{~mm} . \\ \text { Fore limb from axilla } & 16 \mathrm{~mm} . \\ \text { Hind limb from vent } & 41 \mathrm{~mm} . \\ \text { Vent to heel } & 27 \mathrm{~mm} \text {. }\end{array}$

A second specimen (M. C. Z. 3,119) shows all the characters of the type except that the brown of the upper surface is somewhat variegated or marbled 
with lighter and darker; another in the private collection of the junior author is similar.

Eleutherodactylus plicatus is only known from a small series all secured upon Monte Libano near Guantanamo; taken under stones and debris together with $E$. dimidiatus, E. ricordii, and Phyllobates limbatus along brooks in deep woods, at La Union, where the road from San Fernando, Yateras, running west meets the highway from Guantanamo to Sagua de Tanamo; it has never been found elsewhere. In its general appearance it recalls $E$. cuneatus, but differs strikingly from that species in having a peculiarly broad, rounded head and in a remarkably rugose dorsum.

10. Eleutherodactylus varians (Gundlach \& Peters).

Plate 13, fig. 12-14.

Ranita; Ventorilla; Campanilla.

Diagnosis:- A very small terrestrial frog, with no digital dilations and having a coarsely granular belly. The tympanum is large, about two thirds as large as the eye, the rows of teeth on the palate being rather short, and straight but directed so as to converge slightly posteriorly.

Description:- Young M. C. Z. 3,721. Cuba: Valley of Luis Lazo, January, 1917. Thomas Barbour.

Tongue, oval, narrow and entire behind; vomerine teeth in two rather short, straight series, the outer extremity of each series is some little distance behind but not outside (laterad) the corresponding choana, the series slants slightly posteriorly and converges with its fellow, they are separated by a considerable interspace; head broad and rounded, wider than the body; snout flat, scarcely declivous; interorbital space distinctly wider than an upper eyelid; tympanum large, round, about two thirds the diameter of the eye, its distance from the eye distinctly less than its own diameter; dises on fingers not developed, first finger not quite as long as second; first toe much shorter than second; subarticular tubercles poorly developed, a number of small scattered plantar tubercles; a very feeble inner and outer metatarsal tubercle; no tarsal fold; the hind limb being carried forward along the body the tibiotarsal articulation reaches the anterior border of the eye, bent vertically to the axis of the body the heels meet; skin above coarsely granular; belly and hinder aspect of thighs coarsely granular; a faintly indicated ventral discoidal fold. 
Colour (in fresh specimen):- Brown, with many lighter cross-streaks on nape and body. Belly white, throat and lower side of legs dusky brown.

$\begin{array}{lr}\text { Dimensions: - Tip of snout to vent } & 16.5 \mathrm{~mm} \text {. } \\ \text { Width of head } & 7 \mathrm{~mm} \text {. } \\ \text { Diameter of eye } & 2 \mathrm{~mm} \text {. } \\ \text { Diameter of tympanum } & 1.6 \mathrm{~mm} \text {. } \\ \text { Fore limb from axilla } & 11 \mathrm{~mm} \text {. } \\ \text { Hind limb from vent } & 25 \mathrm{~mm} \text {. } \\ \text { Vent to heel } & 14 \mathrm{~mm} \text {. }\end{array}$

Gundlach does not mention exactly whence the types came but stating that the species lives in the woods, is rarely found in cultivated regions or near towns and that its voice is that of a tiny bell which while faint is so penetrating that it may be heard a great distance. The voice it has in common with the other terrestrial Cuban Eleutherodactyli.

During January, 1917, the senior author took twenty-five young examples which undoubtedly belong to this species, in the decaying vegetable trash of an "hoyo" in the Sierra at Luis Lazo, which had many years ago been planted to coffee. The little frogs were excessively active and reminded one of nothing so much as crickets. Their colouration was uniform and peculiar in consisting of a dark brown upper surface crossed by eight or ten narrow transverse bands of lighter brown, giving a decidedly zebra-like effect. 'The lower side of the belly was white but the throat and lower surfaces of legs were dusky brown.

Curiously enough in all our excursions we had never previously taken this frog. A careful reèxamination of the series from Soledad recorded as $E$. varians (Mem. M. C. Z., 1914, 44, p. 245) makes it quite clear that they were really the young of E. ricordii. Stejneger (Proc. U. S. N. M., 1917, 53, p. 263) shows that Palmer and Riley took it at Mariel, San Diego de los Baños, and at El Guamá.

\section{Eleutherodactylus auriculatus (Cope).}

Plate 6, fig. 2, 3.

\section{Ranita de los Curujéyes.}

Diagnosis:- A small frog with granular belly, vomerine teeth in two short straight series not extending laterally beyond the choanae, nostrils very near tip of snout and well-developed dises on fingers and toes. 
Description:-Adult M. C. Z. 3,117. Cuba: Guantanamo, Monte Libano, El Perú, 1914. C. T. Ramsden.

Tongue narrow, oval, slightly nicked behind; vomerine teeth in two short groups, which are oblique and a short distance behind the choanae, not extending beyond the latter laterally and converging backward near the median line, the interval between the groups about equal to the distance from the choanae; nostrils very near tip of snout, their distance from the eye equalling its diameter; upper eyelids narrower than interorbital space; tympanum rather small, about one half the diameter of the eye, its distance from the eye a little less than its diameter; fingers with well-developed dises, first finger equalling second in length; dises of fourth and fifth toes equalling those of fingers, others slightly smaller; tip of first toe reaching the base of the dise of the second; two inconspicuous metatarsal tubercles; soles smooth except for a very few undeveloped tubercles; no tarsal fold; the bent limbs being pressed along the side, knee and elbow overlap; hind limb being extended along the side of the body, the heel reaches the anterior border of the eye; hind limbs being placed vertically to the axis of the body, the heels overlap considerably; skin above with a very few scattered granules on back and sides, a very fine, scarcely perceptible middorsal glandular ridge; belly and posterior aspect of thighs strongly granular; throat and anterior aspect of thighs smooth; belly without a modified discoidal area.

Colour (in alcohol):- Uniform brown above, lighter beneath.

$\begin{array}{lr}\text { Dimensions: - Tip of snout to vent } & 29 \mathrm{~mm} . \\ \text { Width of head } & 4.2 \mathrm{~mm} \text {. } \\ \text { Diameter of eye } & 3.8 \mathrm{~mm} . \\ \text { Diameter of tympanum } & 1.9 \mathrm{~mm} \text {. } \\ \text { Fore limb from axilla } & 16.5 \mathrm{~mm} \text {. } \\ \text { Hind limb from vent } & 45.5 \mathrm{~mm} \text {. } \\ \text { Vent to heel } & 24.5 \mathrm{~mm} .\end{array}$

As Stejneger has well said in his Herpetology of Porto Rico (p. 585) the variations in colour seen in this frog are simply endless. A specimen taken at the Sierra de Guane in March 1915 is dark slaty above with a conspicuous white middorsal line, with dark and light spots and small blotches upon throat and sides. It is therefore useless to dwell upon the colouration of a creature which probably not only varies individually almost infinitely, but earh individual itself may also vary from time to time. 
The history of our knowledge of this species is rather peculiar. It was first found by the botanist Charles Wright probably at Monte Verde, whence came most, if not all, of his specimens which were described by Cope as from "Eastern Cyba." The species subsequently remained unknown in Cuba for many years. In the meanwhile Stejneger in his Herpetology of Porto Rico (p. 583 et seq.) had shown that what had for a long time been called martinicensis in Porto Rico was really Cope's auriculatus and since then it has been recorded from Haiti. In 1914 one of us (Ramsden) found it again in the mountains about Guantanamo where it appears to be confined to the "curujéyes" or epiphytic bromeliaceous plants - at any rate there; elsewhere it seems very rare in Cuba. In 1915, nevertheless, a typical example, not fully adult, however, was taken under a decaying log near where the Rio Cuyaguateje passes by the foot of the Sierra de Guane, in western Cuba (Barbour).

Regarding the habits of this little frog, which curiously enough is excessively abundant in Porto Rico, we cannot do better than to quote Stejneger who says:-

"Although by no means confined to living on or among the trees this species probably" deserves the name of tree toad more than any of the other species of the genus inhabiting these islands. A favorite place of concealment during the day we found to be the axils of the leaves of palms and liliaceous plants, but it was also caught under the bark of trees, fallen logs, stones, or in crevices in the rocks, clay banks, or in holes in trees.

"They keep usually quiet during the day, but toward dusk they come out from their hiding places, and the island then begins to resound with their call notes. These, I believe to be different in the adults and the young. The former utter $a$ loud and rather sonorous

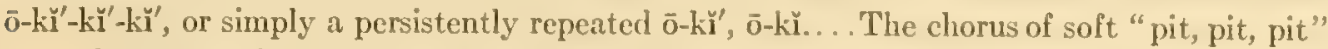
around our camp in the evening I attributed to these young ones.

"Living specimens placed in a glass jar adhere to the sides chiefly by their digital pads or disks. The belly is flattened against the glass, but there is apparently no special adhesive area.

"The reproduction of this species is most extraordinary in that the young escape from the egg a full developed frog without undergoing any tadpole stage or metamorphosis. The eggs are usually deposited in the damp axils of an air plant, about 20 to $30 \mathrm{in} \mathrm{a} \mathrm{lump.} \mathrm{The}$ development of the young in the egg is remarkable for the fact that the anterior and posterior limbs appear simultaneously and that there is no trace of gills. In about three weeks the young escape from the egg, the only sign of immaturity being a short rudiment of tail, which is absorbed, however, in a few hours. The discovery of this extraordinary batrachian development, which so strongly foreshadows that of the amniote vertebrates, was made by Dr. Bello y Espinosa in 1870, and has been confirmed and elaborated by Gundlach and Peters." (StejNeger, Rept. U. S. N. M. for 1902, 1904, p. 587-588). 


\section{RANIDAE.}

\section{Phyllobates lmbatus Cope.}

Plate 1, fig. 4.

Diagnosis:- Probably the smallest of living amphibians, a tiny terrestrial frog, rich maroon-brown with a yellow stripe on the thighs, sides of the body and around the head, meeting on the tip of the nose.

Description:-Adult M. C. Z. 7,843. Cuba: Colonia Guabairo near Cienfuegos, February, 1910. Rosamond and Thomas Barbour.

Tongue oval, entire; body rather stout; head not wider than body; snout rather abruptly acute; skin of back and sides very finely granular, skin of belly smooth; tympanum two thirds the diameter of the orbit, its distance from the latter a little less than its own diameter; nostril much nearer tip of snout than eye; subarticular tubercles very feebly developed, a very weak outer, no inner, metatarsal tubercle; the hind limb being extended along the body the heel just reaches the posterior border of the orbit, the limbs being flexed vertically to the axis of the body the heels fail to meet by a considerable distance.

Colour (in life):- Above rich, lustrous maroon-brown; a brilliant yellow band extends from the tip of the snout, along each side and down the thighs to the knee; sides of body below the yellow line and front aspects of thighs black; elsewhere limbs chestnut-brown; belly yellowish cream-colour.

$\begin{array}{cr}\text { Dimensions: - Tip of snout to vent } & 11.5 \mathrm{~mm} \text {. } \\ \text { Width of head } & 3.5 \mathrm{~mm} \text {. } \\ \text { Fore limb from axilla } & 6.5 \mathrm{~mm} \text {. } \\ \text { Hind limb from vent } & 16.5 \mathrm{~mm} \text {. } \\ \text { Vent to heel } & 10 \mathrm{~mm} \text {. }\end{array}$

This is the most delicate and beautifully coloured amphibian known to us. It was one of the remarkable discoveries made by that most excellent collector Charles Wright, in the vicinity of Guantanamo. The types, probably from Monte Verde, are in the U. S. N. M., though dried up beyond recognition. The species was rediscovered at two localities on the Soledad Estate in 1910 (Barbour) and a few years later it was found once more near Wright's old typelocality in the mountains near Guantanamo, at La Union, on Monte Libano, Monte Toro, Yateras, Bayate, Belona and at La Cobrera (Ramsden). In 1915 de la Torre sent a single specimen to the M. C. Z. from Cayo del Rey 
near Alto Cedro, also in Oriente. Much more startling, however, was the capture in 1915 of a single adult at San Antonio de los Baños not far from Havana (Barbour). These are the only records of which we are aware, where the locality is exactly known. There is a specimen in the British Museum (P. Z. S., 1890, p. 324) which Dr. Boulenger writes was purchased from the natural history institute "Linnaea" with merely Cuba for data.

As to the habits of $P$. limbatus we can contribute but little. It seems to be confined to a limestone substratum and is found by day hidden under stones or damp leaves in moist situations. It is astonishingly active and when once spied out it is by no means easy to eatch. One needs forceps and must work carefully lest the tiny creature be badly injured. It is noteworthy that the smallest bird, Calyple helenae (Gundlach), is peculiar to Cuba, and that on the same island occurs Sphaerodactylus elegans Reinhardt \& Lütken, the smallest reptile, and Phyllobates limbatus Cope, which is certainly one of the smallest if not the very smallest amphibian known. However, almost equally minute species of Arthroleptis and Nectophryne occur in the Seychelles Islands.

Phyllobates bicolor Bibron which was aseribed to Cuba in la Sagra's History (Rept. 1840, pl. 29, bis), and which appears also in Gundlach's Erpetologia Cubana (1880, p. 88) is beyond doubt some non-Cuban form. It probably got mixed in with the Cuban collections which were forwarded to Paris for study for publication in the la Sagra series. It is perhaps Mexican, for a number of species of shells now known to be from that country occur in d'Orbigny's volume on the Mollusques.

\section{REPTILIA: SAURIA.}

Key to the Genera.

$\mathrm{a}^{1}$ Four limbs.

$\mathrm{b}^{1}$ Head corered with scales or small plates.

$\mathrm{c}^{1}$ Eyelids undeveloped, pupil verticals.

$\mathrm{d}^{\mathrm{t}}$ Tocs compressed, undilated ........... Gonalodes, p. 114

$d^{2}$ Toes dilated.

$\mathrm{e}^{\mathrm{l}}$ Toes dilated at the tip only . . . . . . . . Sphacrodaclylus, p. 119

$\mathrm{e}^{2}$ Toes clilated at the base.

f 'Terminal portion of each toc frec, raised upward, all tocs clawed. . . . . . . . . . If midaclylus, p. 117

$\mathrm{c}^{2}$ Eyclids functional, pupils round.

$f^{2}$ Only third and fourth toes clawed . . . . . Tarentola, p. 116

$\mathrm{d}^{1}$ 'locs dilated.

$\mathrm{e}^{1}$ A transverse gular fold . . . . . . . . . . Deiroptyx, p. 130

$\mathrm{e}^{2}$ \& longitudinal gular pouch.

f1 Squamation heterogeneous, body with mixed scales of greatly varying size ............ Chamaclcolis, p. 128 


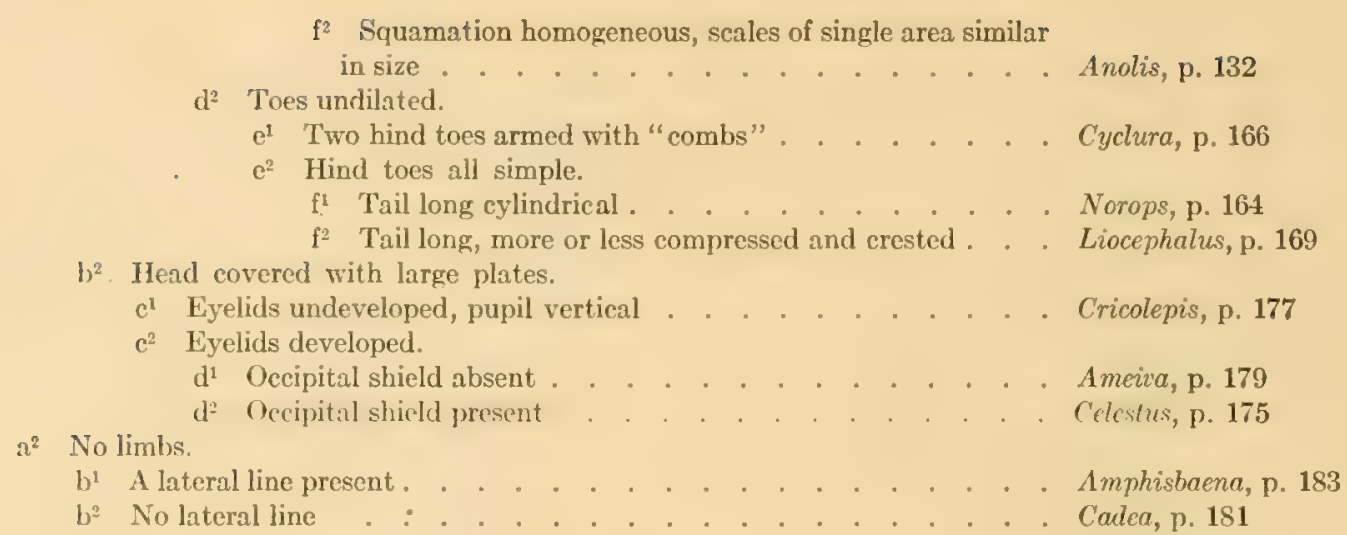

GEKKonidae.

13. Gonatodes fuscus (Hallowell).

Plate 1, fig. 5.

Salamanquita.

Diagnosis: - A heavy bodied, thick tailed nocturnal lizard which differs from the other Cuban geckonids by having round pupils, the eyelid distinct all around the eye and no dilatation of the digits.

Description:-Adult o M. C. Z. 1,922. Cuba: Havana, University grounds, 1913. V. J. Rodriguez.

Head short and rather high; snout obtusely rounded, rather short, as long as distance of eye to ear opening; ear opening broadly oval; forehead slightly concave; limbs and body rather short and stout; digits slender, compressed at the base, the scales under the basal joint enlarged; upper parts all covered with minute even granules, those on the snout somewhat enlarged; rostral roughly a pentagon, almost twice as broad as high, with a long median crest above; nostril between the rostral and three or four small surrounding scales; labials posteriorly ill defined, about five or six upper labials distinctly enlarged and four or five lower; mental large, followed by two or three slightly enlarged chin-shields, followed by other scales which pass almost immediately into the granules of the throat; scales of abdomen, rather large, flat, rounded, and strongly imbricating; tail cylindrical, tapering, covered above with small, round, imbricating scales, those below. larger with a median series distinctly expanded.

Colour (in life):- Adult male. Iris neutral gray; head ochraceous yellow, turning to orange-red below; neck same colour as head, with a narrow dark 
brown median line extending to base of skull. Narrow pale cerulean blue line on labials, extending beyond opening of the mouth. A small cerulean blue spot, formed by four scales, above the ear (this is not always present). Another cerulean blue line on shoulder where the ochraceous area meets the body-colour. Body above slate-blue sprinkled with ochraceous scales. Tail velvety black for three fourths of its length, turning to gray until the last quarter inch, which is white. Feet pale snake-gray.

Females, variegated, gray of a rather light shade marked with brown blotches of varying intensity, the white vertical shoulder band distinet but not always edged with darker; belly whitish. The colours of the male become very brilliant when mating.

The status of this lizard in Cuba is far from clear. Gundlach found it only in houses in Havana and Santiago de Cuba and our extensive collecting has never revealed it as a denizen of the country or wilder districts. We have found it by no means abundantly in both Havana and Santiago de Cuba, where Wirt Robinson also took it in 1903. It is abundant at Guantanamo but only in houses and never in the country. It is certainly suggestive that these three localities are all maritime ports of entry of great commercial importance. The M. C. Z. has a few specimens from Kingston, Jamaica, and it was suggested (Barbour, Bull. M. C. Z., 1910, 52, p. 289) that the lizard probably reached that port from Santiago. Whether or not Gonatodes notatus (Reinhardt and Lütken) from Haiti is this species or distinct we cannot say, as no examples are available for examination. The original description suggests a valid form, but Boulenger has included notatus, with a query, in the synonymy of albogularis (Cat. lizards Brit. mus., 1885, 1, p. 59); a surmise very likely to be justified. Whether this gecko has been accidentally established in some one of the localities mentioned and then spread to the others; whether it has become modified into a valid race after reaching the Antilles; whether or not it occurs upon the mainland or whether perhaps the apparently different $G$. fuscus of the continent is the ancestral form, are all suggestive topics for speculation. At any rate it is very unlikely that the Gonatodes should be considered anything but a recent accidental immigrant to Cuba and it should probably not therefore be considered, as it has been in the past, an integral part of the fauna of the Island.

Since this was written Dr. Stejneger has answered some of our queries. First he has compared Haitian and Cuban specimens and found them distinet, so that the name $G$. notatus cannot be discarded. Then also he has shown 
conclusively that the name of fuscus and not albogularis must be used for Cuban species, Cuban examples being identical with those from Nicaragua, the typelocality of fuscus, while albogularis first came from Martinique. Or rather, we would suggest, may have come from Martinique for the record is based on a Plée specimen and thus it may have come from almost anywhere in the Lesser Antilles, so worthless were the Plée data.

Stejneger also records examples from Mariel (Proc. U. S. N. M., 1917, 53, p. 264, 265).

\section{Tarentola cubana (Gundlach \& Peters).}

Plate 14, fig. 1.

Dormilona; Salamanquesa; Peninqué.

Diagnosis: - A large stout, sluggish, nocturnal lizard, with the digits gréatly dilated and with the back covered with rows of prominent trihedral tubercles. The eyes are large, without lids and the pupil is vertical.

Description:- Adult M. C. Z. 11,871. Cuba: Oriente; Cabo Maisí, La Patana, May, 1916. Carlos de la Torre and V. J. Rodriguez.

No supraorbital bone; snout as long as distance from the eye to a point midway to the axilla; rostral about twice as high as broad; nine upper labials, the last two much smaller than the others; mental about once and one half as long as its breadth at the labial margin, its posterior border hardly one third as long as its anterior; a pair of enlarged chin shields border the posterior half of the mental (the first infralabials the anterior half), enlarged chin shields then extend out behind the infralabials in a series diminishing in size; eight lower labials, the last very small; anterior and posterior border of ear opening bordered with five or six elongate denticles; back and sides with seventeen more or less irregular rows of large conical tubercles; tail with verticils, usually separated by five rows of scales, the limiting row enlarged and tubercular.

Colour (in life):- Grayish or whitish (varying); the back with six irregular rows of dark blotches, often confluent into longitudinal bands; a horse-shoe or chevron-shaped dark mark upon the head; the second lateral line of blotches on each side meets a heavy dark streak behind each eye.

$$
\begin{array}{cr}
\text { Dimensions: - Total length (tail partly reproduced) } & 194 \mathrm{~mm} . \\
\text { Tip of snout to vent } & 102 \mathrm{~mm} . \\
\text { Vent to tip of tail } & ? \mathrm{~mm} .
\end{array}
$$


Width of head

Fore limb

Hind limb
$21 \mathrm{~mm}$.

$32 \mathrm{~mm}$.

$40 \mathrm{~mm}$.

The Dormilona is generally a very rare lizard. Only occasionally will some particular locality be found where they may be obtained easily. One such locality is Puerto Escondido not far from Guantanamo Bay, where the junior author has found a number of specimens in and under a dead dry cactus locally called "Cardona." Although adult all these specimens are small compared to those from Maisí. In some of the cliffs of the Farallones de Maisi, Torre, and Rodriguez collected the species living closely pressed into crevices of the limestone rock, almost abundantly. Other occurrences are Sierra de Rangel, near San Diego de los Baños (Gundlach); Santiago de Cuba (Wirt Robinson); Cabo Cruz, Los Negros in Jiguani and Pinar del Rio Province (Barbour). It is, however, extremely rare outside of the few stations in the Province of Oriente already mentioned. It is, of course, nocturnal and as to its habits and activities nothing can be said. It is found occasionally under the bark of a dead and decayed tree (the junior author found two under the bark of a dead tree at Cayo Smith in the harbor of Santiago de Cuba), but much more often about limestone outcrops, either under loose blocks of stone or in crannies and crevices. It grows to a very considerable size and the specimen described would be a veritable monster were its tail perfect. We have, however, never seen a really large adult which has not reproduced its tail on one or more occasions.

\section{Hemidactylus mabouia (Moreau de Jonnès).}

\section{Salamanquesa.}

Diagnosis: - A depressed nocturnal lizard, having the toes dilated and the terminal portion of each toe raised at an angle from the base and terminating in a curved claw.

Description:- Adult M. C. Z. 8,502. Cuba: Matanzas, 1913. V.J. Rodriguez.

Rostral much broader than high, with a reentrant in its posterior margin for the forward angle of the internasal and a long median cleft in contact with two supranasals and a small median shield wedged between them; first supralabial in contact with the lower postnasal and reaching the nostril; nostril pierced between rostral, first supralabial and three nasals, the upper one or 
supranasal being much the largest; twelve supralabials, the suture between eighth and ninth below centre of eye; top of head covered with granules which are enlarged upon snout and specially upon canthal areas; ear opening oval, a little oblique; temples covered with fine granules but with a few scattered enlarged tubercular scales; mental wide, triangular; seven large infralabials; four chin-shields in a row, the median pair greatly enlarged, hexagonal; upper surface of body and flanks covered with small granules mixed with large tubercles, which are not keeled; the tubercles in more or less irregular longitudinal series from fourteen to sixteen across the middle of back; throat with small flat uniform scales, scales of under parts of body and limbs cycloid and imbricate, as large as the largest dorsal tubercles; fourteen or fifteen femoral pores on each side; fingers and toes without interdigital membranes, with compressed and upward raised and clawed terminal phalanges; dilated basal portion with four divided lamellae under inner toe and seven under middle toe, beside the large single distal lamella; tail round, somewhat depressed at the base, covered with enlarged granules and with six rows of conical tubercles set in whorls about six or seven scales separating each whorl; under surface with a median series of large dilated plates.

Colour (in life):- Grayish or whitish, uniform or becoming clouded or marbled with dusky; rarely becoming almost uniform dusky brown.

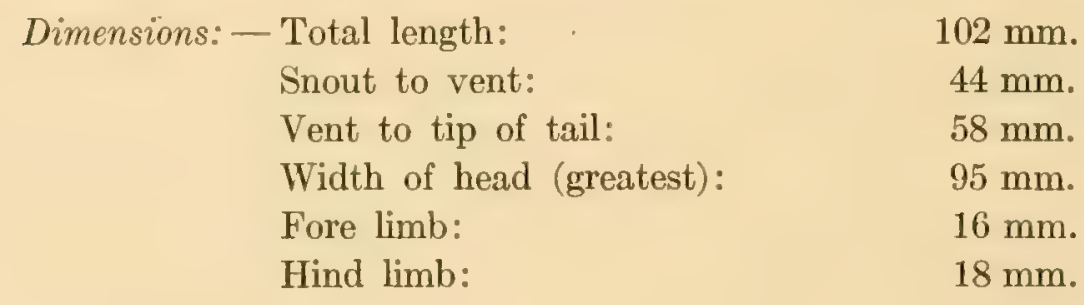

While this species may be really African it has become widely established in America. In Cuba Gundlach reported it very common in Havana and said that he had seen it in the Sierra de Rangel and at Cabo Cruz. This is interesting since we have observed it only in cities or well-populated towns. In the outskirts of Havana and Matanzas it may often be seen at night lurking on the walls of houses near the old-fashioned gas- or oil-lamps in search of insects. We have often been told that it cannot stand the glare of modern electric lights and we have never seen it about them. Palmer and Riley found it at Mariel and we have heard of it in Santiago de Cuba.

The species was not improbably brought to America during the extensive 
commerce of slave-trading days, and it is now impossible to define its original range. As an evidence of its great and somewhat erratic distribution a list of the localities from which there are specimens in the M. C. Z. is not without interest. From Africa there are examples from Zanzibar, Mozambique, Mombasa, and Madagascar; beside those from Cuba there are specimens from the West Indian Islands of Trinidad, St. Lucia, Martinique, Petit Martinique, St. Kitts, Haiti, and Porto Rico. 'That it is widespread upon the mainland is evidenced by specimens from Acapulco, Mexico, as well as from Para, Rio de Janeiro, Saõ Sabastaõ, Vazouras, Santa Clara, and the Rio Mucury, Brazil. That the species occurs so far inland and is so widespread in Brazil is certainly suggestive if not indicating native habitat.

\section{Key to the Species of Sphaerrodactylus.}

$a^{1}$ Scales of body minutely granular.

$b^{1}$ Body grayish, dotted or vermiculated with lighter, size large . . . . . cinereus, p. 122

$b^{2} \quad$ Body marked with more or less distinct cross-bands.

$\mathrm{c}^{l}$ One postnasal, snout acute, tail usually bright red, size very small . (elegans, p. 121

$c^{2} \quad$ Two or three postnasals, snout rather rounded, tail never red . . . torrei, p. 119

$\mathrm{a}^{2}$ Scales of body keeled and overlapping.

$b^{1}$ Scales very small, almost granular, although distinetly keeled and imbricate

$b^{2}$ Scales rather large, heavily kecled.

$\mathrm{e}^{1}$ No narrow median dorsal zone of fine granules. . . . . . . . notatus, p. 125

$c^{2} \quad$ A narrow median dorsal zone of fine granules . . . . . . . . scaber, p. 126

16. Sphaerodactylus torrei Barbour.

Plate 2, fig. 1, 2.

Salamanquita de la Torre.

Diagnosis:- $\mathrm{A}$ medium sized, stout bodied species, with fine granular dorsal scales, very variously marked with broad dark cross-bands upon a gray ground-colour.

Description:- Adult M. C. Z. 8,510. Cuba: Cabo Cruz, March, 1913. Thomas Barbour.

Snout rather short and rounded (longer and more acutely pointed in $e . g$. M. C. Z. 8,508 from Guantanamo); the distance from the tip of the snout to the eye being slightly greater than the distance between the eye and car; rostral rather large with a long median cleft behind; nostril between rostral, first supralabials, two (or three) small postnasals and a moderately sized supranasal, which is separated from its fellow on the opposite side by a somewhat smaller roughly hexagonal median scale, the three bordering the rostral above; four 
large (or four large and one small) supralabials to below the centre of the eye; a spine on the superciliary margin over the centre of the eye; head above and on sides covered with fine granular scales enlarged upon the snout; scales of back all tiny round granules; mental large, larger than rostral; two very large infralabials, followed by two much smaller ones to below the centre of the eye; two squarish, slightly elongate chin-shields behind the mental followed by some enlarged flat scales which grow smaller and pass gradually into the tiny scales of the midgular region; scales of chest and belly, rounded, flat, and imbricate; scales of limbs and tail smaller than ventrals, smooth also, and imbricating; a very poorly defined series of enlarged scales along the under side of the tail.

Colour (in life): - Very variously marked with cross-bands on a darker or lighter gray ground-colour. The dark cross-band may be much wider than the lighter interspaces; they may vary greatly in depth of colour. Sometimes the dark bands are darker edged and have ocelli arranged a pair to each band within them.

Dimensions: - Total length

Tip of snout to vent

Vent to tip of tail

Greatest width of head

Tip of snout to ear

Fore limb

Hind limb
55 mm. (M.C.Z. 8,508, Guantanamo, in house, C. T. Ramsden).

$29 \mathrm{~mm}$.

$26 \mathrm{~mm}$.

$5 \mathrm{~mm}$.

$7.5 \mathrm{~mm}$.

$6.5 \mathrm{~mm}$.

$9 \mathrm{~mm}$.

De la Torre's Gecko is apparently confined to the Province of Oriente, the specimens in the Museum being from Cabo Cruz, Santiago de Cuba, and Guantanamo.

Gundlach who called this species sputator (Erp. Cub., 1880, p. 56) confused elegans with it, although he noticed that his examples from Cabo Cruz were different. It was called sputator until we pointed out that the name was inapplicable as it referred to a different species from St. Eustatius (Barbour, M. C. Z., 1914, 44, p. 260). It is not by any means a common species and the examples taken at Cabo Cruz were under stones not far from the lighthouse. The types, three specimens (M. C. Z. 6,916) were taken at Santiago de Cuba in December 1903 by Lieut. (now Col.) Wirt Robinson. The junior author has received recently a specimen from near Cotorro, Havana Provinee, which may indicate that the species is much more widespread. If so it is surely excessively rare outside of Oriente. 


\section{Sphaerodactylus elegans Macleay.}

Plate 2, fig. 3.

\section{Salamanquita de la Virgen.}

Diagnosis: - A tiny species with sharply defined cross-bands which do not meet across the belly, and a coral-red tail on which the cross-bands become mere spots on its upper surface. The dorsal scales are tiny granules, the ventrals extremely small and smooth.

Description:-Adult M. C. Z. 7,921. Cuba: San Diego de los Baños, April, 1910. Thomas Barbour.

Snout rather pointed, the distance from the tip to the eye being about equal to the distance of the latter from the ear opening; rostral rather large with a long median cleft behind; nostril between the rostral, first supralabial, a small postnasal and a distinctly larger supranasal which is separated from its fellow on the opposite side by a single median scale not very much smaller than one of the supranasals, these three scales border the rostral above; four large supralabials, (on one side the third is divided, a common occurrence), the fourth supralabial below the centre of the eye; a spine on the superciliary margin above the centre of the eye; head above and on the sides covered with minute granular scales, slightly larger and flatter on the snout; scales of back very minute and granular; mental larger than rostral; two large and one small infralabial to below the centre of the eye; two small pentagonal chin-shields bordering mental between the large first infralabials followed by smaller flat scales which decrease in size and become extremely small on middle of throat; scales of chest and belly small, rounded, slightly imbricate; scales on upper surface of tail granular, below flatter with a median series of enlarged flat transverse plates.

Colour (in life): - Slaty gray above, rather light in tone; the head with two narrow bands between the eyes of much darker slate, the nape with two, the neck with two, and the body between fore and hind limbs with six crossbands. On the tail there are five bands but the three hinder ones are simply spots. The distal three fifths of the tail is unmarked. The tail, distally where unbanded and wholly below, is rosy pink. The belly is pinkish gray. The bands on the head extend to the chin but do not quite meet.

$\begin{array}{cc}\text { Dimensions: - Total length } & 34 \mathrm{~mm} . \\ \text { Tip of snout to vent } & 17 \mathrm{~mm} . \\ \text { Vent to tip of tail } & 17 \mathrm{~mm} .\end{array}$




$\begin{array}{lr}\text { Greatest width of head } & 4 \mathrm{~mm} . \\ \text { Tip of snout to ear } & 4.5 \mathrm{~mm} \text {. } \\ \text { Fore limb } & 5.5 \mathrm{~mm} \text {. } \\ \text { Hind limb } & 6.5 \mathrm{~mm} .\end{array}$

Sphaerodactylus elegans, a very well-named species, does not vary in colour in the manner of so many other Sphaerodactyli. To be sure there is some variation in the breadth and intensity of the bands but the species is easily determined by its markings and its minute size. It is probably the smallest known reptile.

It is not a rare species but it is one which we have but very rarely found outside of houses. Perhaps because it is so much more easily seen on a smooth white wall than in wilder surroundings. It spends its time by day behind furniture, books, and pictures and sallies forth when dusk comes, scurrying about after its prey of tiny insects. Dr. Faxon suggests its native name is probably due to the fact that it is found commonly behind pictures and in Cuba pictures of the Virgin are often the only ones in the poorer houses.

While elegans seems to be found in Haiti we cannot find any record for its occurrence in the Province of Oriente in Cuba. The M. C. Z. has specimens from San Diego de los Baños, Santiago de la Vega, Remedios, Caibarién and other western localities as well as from the Island of Pines.

Stejneger (Proc. U. S. N. M., 31 May, 1917, 53, p. 266) calls attention to the fact that this lizard, usually credited to Reinhardt and Lütken, should be ascribed to MacLeay.

18. Sphaerodactylus cinereus MacLeay.

Plate 2, fig. 4.

\section{Salamanquita.}

Diagnosis: - A rather large Sphaerodactylus with granular dorsal scales, much larger smooth ventrals. Ashy or dusky gray in colour finely dotted with white except about the region of the head and neck, which is finely vermiculate.

Description:-Adult M. C. Z. 7,916. Cuba: San Diego de los Baños, April, 1910. Thomas Barbour.

Snout rather flat and pointed, the distance from the tip to the eye being slightly longer than the distance from the eye to the ear opening; rostral moderately large with a long median cleft behind, nostril between rostral, first supra- 
labial, a single small postnasal and a much larger supranasal which is separated from its fellow on the opposite side by a single much smaller median scale, these three bordering the rostral above; four large supralabials to the centre of the eye; a spine on the superciliary margin over the centre of the eye; head above and on sides covered with fine granules, those of the snout much enlarged and flattened; scales on back small and granular; mental large, larger than rostral; two large and one small roughly pentagonal chin-shields which are followed by flat, pavement-like scales which pass gradually into tiny round scales of the middle throat; belly with enlarged, smooth, rounded imbricate scales; tail with smooth, round, imbricating scales above and below, also a series of wide plates below on the median line.

Colour (in life): - Uniform gray, lighter below; above finely punctate with white, streaked with fine white lines on side of head and neck. In some specimens the white appears as distinct vermiculations on the head and anterior body-regions; again the vermiculations may appear to be dark upon a light ground-colour; there is considerable variation. Never, however, has any tendency to cross banding been observed, the striping is invariably longitudinal.

$\begin{array}{lr}\text { Dimensions: - Total length } & 76 \mathrm{~mm} . \\ \text { Tip of snout to vent } & 35 \mathrm{~mm} \text {. } \\ \text { Vent to tip of tail } & 41 \mathrm{~mm} \text {. } \\ \text { Greatest width of head } & 6 \mathrm{~mm} \text {. } \\ \text { Tip of snout to ear } & 9 \mathrm{~mm} . \\ \text { Fore limb } & 10 \mathrm{~mm} \text {. } \\ \text { Hind limb } & 11 \mathrm{~mm} \text {. }\end{array}$

This gray Sphaerodactylus is by no means rare. Its habits are those of many others, found perhaps more often in houses than in the woods these little lizards become one's familiar companions on many occasions. To show how widespread is the form we add the localities of the series in the M. C. Z.:Herradura, Cabo San Antonio, Sierra de Cubitas, Los Negros in Jiguani, Havana, Cienfuegos, San Diego de los Baños, Caibarién, San Antonio de los Baños, also several localities in the Island of Pines and Haiti.

This species has usually been called S. punctatissimus, but Duméril and Bibron's description (Erp. gén., 1836, 3, p. 405) is based upon a specimen without locality, and is not sufficiently detailed to allow one to say surely that the name is applicable to this Cuban species without examining the type.

For use of MacLeay instead of Cocteau for authority consult Stejneger (Proc. U. S. N. M., 1917, 53, p. 266). 


\section{Sphaerodactylus nigropunctatus Gray.}

Plate 3, fig. 1.

Salamanquita.

Diagnosis: - This may be distinguished from all the other Cuban Sphaerodactyli by having very minute dorsal scales which are not granules but elongate keeled scales with a slight tendency to imbricate. On the sides the scales are larger, rounded, more imbricating and more feebly keeled.

Description:- Adult M. C. Z. 8,536. Cuba: Guantanamo, Monte Libano, 1914. C. T. Ramsden.

Snout rather short and blunt, the distance from the tip to the eye being less than that of the eye from the ear; rostral moderate with a very long median cleft behind; nostril between rostral, first supralabial, one postnasal and a very small supranasal, which is separated from its fellow on the opposite side by four small scales, these six scales bordering the rostral posteriorly; three large and one small supralabial to below the centre of the eye; a small spine on the superciliary margin above the centre of the eye; head above and on sides covered with very minute granules, but slightly enlarged upon the snout; scales of back very small, somewhat elongate, keeled and very slightly imbricate; mental moderate, as large as rostral; one very large, followed by a medium and a small infralabial to below the centre of the eye; two small squarish chinshields below the mental followed by a few slightly enlarged scales passing quickly into the small scales of the gular region; scales of chest and belly rounded, smooth, imbricate; scales of tail smaller, irregularly arranged, rounded, smooth, imbricate; with only a very faintly defined series of enlarged scales below.

Colour (in fresh specimen): - Rich mahogany-brown, specked with black, a lighter streak around the head and a series of light dots across the nape.

$\begin{array}{lr}\text { Dimensions: - Total length } & 55 \mathrm{~mm} . \\ \text { Tip of snout to vent } & 29 \mathrm{~mm} \text {. } \\ \text { Vent to tip of tail } & 26 \mathrm{~mm} \text {. } \\ \text { Greatest width of head } & 4 \mathrm{~mm} \text {. } \\ \text { Tip of snout to ear } & 5.5 \mathrm{~mm} \text {. } \\ \text { Fore limb } & 6.5 \mathrm{~mm} \text {. } \\ \text { Hind limb } & 8.5 \mathrm{~mm} \text {. }\end{array}$

Sphaerodactylus nigropunctatus was described by Gray from an example in the British Museum without locality. Until the type can be examined and 
compared with Cuban specimens it will be impossible to be positive that they are correctly identified. Garman, however, studying a series from Santiago de Cuba (Wirt Robinson collector) gave them this name and after a reexamination of the material we agree with him. There are a few examples in the M. C. Z. from San Domingo and Oriente in Cuba. This is the species which Gundlach said was so rare and of which he had only caught two examples in Santiago de Cuba - probably meaning the Province, as Oriente was so-called before Cuban dependence. He confused the species with Sphaerodactylus argus Gosse which is really a species wholly confined to Jamaica.

\section{Sphaerodactylus notatus Baird.}

Plate 3, fig. 2.

\section{Salamanquita.}

Diagnosis: - A small species with rather enlarged, overlapping, keeled dorsal scales but with no middorsal zone of smaller scales.

Description:- Adult M. C. Z. 8,513. Cuba: Guantanamo, Monte Libano, March, 1913. Thomas Barbour and C. T. Ramsden.

Snout moderately long but not very acutely pointed; the distance from the tip of the snout to the eye being slightly greater than the distance from the latter to the ear; rostral moderate with a long median cleft behind; nostril between rostral, first supralabial, a postnasal (or two) and a slightly cnlarged supranasal which is separated from its fellow on the opposite side by one (or often two) small median scales, these three (or four) scales border the rostral above; three large supralabials to below the centre of the eye; a small spine on the superciliary margin above the centre of the eye; head above and on sides covered with fine granules, enlarged and flattened upon the snout; scales on back enlarged, keeled, imbricate, about ten or twelve equal to the distance from the tip of snout to ear; mental moderate, about the size of the rostral; two small roughly pentagonal scales border the mental posteriorly; two (or three) large infralabials to below the centre of the eye; gular scales minute except for a few near the postmentals which are slightly enlarged; scales of chest and belly smooth, rounded, enlarged (but not quite as large as dorsals), and imbricate; tail with somewhat irregularly arranged, rounded, imbricate, smooth scales, no conspicuous series of transversely enlarged scales below.

Colour (in life): - Very variable, often uniform brown lighter below and 
on the tail; perhaps more often with darker stripes and bars; sometimes a pair of white dots which may or may not be in a spectacle-like marking is found upon the shoulder region; the head usually has a dark median band and dark bands upon the sides running through the eyes and along the canthi.

$\begin{array}{lr}\text { Dimensions: - Total length } & 49 \mathrm{~mm} . \\ \text { Tip of snout to vent } & 25 \mathrm{~mm} . \\ \text { Vent to tip of tail } & 24 \mathrm{~mm} . \\ \text { Greatest width of head } & 4 \mathrm{~mm} . \\ \text { Fore limb } & 6.5 \mathrm{~mm} . \\ \text { Hind limb } & 8 \mathrm{~mm} .\end{array}$

Sphaerodactylus notatus is one of the most widely distributed species in the genus. It is found abundantly all over Cuba, we have taken it from Guane to Guantanamo and Rodriguez found it at Baracoa. It is also common upon the Island of Pines, upon New Providence, Great and Little Abaco, and a number of other islands and cays of the Bahamas. The types came from Key West and the M. C. Z. has specimens from there caught by both Count Pourtalès and Garman. It probably was originally accidentally introduced but seems to have become well established.

It is found commonly in the woods in Cuba and the Bahamas, but sometimes enters houses, living by day hidden in some nook or cranny. When collecting insects in the forest, and tearing open rotten logs, one often meets with small single eggs, pure white, and about $3 \times 5 \mathrm{~mm}$. in size and as the obvious parent is so often near by there cannot be much doubt but that these are the eggs of Sphaerodactylus. That they are laid singly is of interest, not only because this is also the habit with Anolis but because many other geckos both of the Old World and the New, e.g. Ptychozoon and Aristelliger, lay their eggs in pairs. The pairs are evidently laid while soft and sticky and usually are so closely approximated as to indent one another. They are stuck fast to the surface of some crevice on, or in the hollow of, a large tree. They take a long time to hatch.

21. Sphaerodactylus scaber, sp. nov.

Plate 3, fig. 3.

Sabandija.

Diagnosis: - A large species, the back covered with large, heavily keeled scales which are about as long as broad. The neck and back with a very narrow median zone of very small scales. The head is covered with extremely 
minute granules and the belly-scales are large and smooth. The tail is long and slender with round, overlapping, smooth scales above and below.

Description:- Adult \& M. C. Z. 12,304. Cuba: Camaguey; Sierra de San Juan de los Perros. Thomas Barbour.

Snout pointed and elongate, the distance from the tip to the eye being distinctly longer than that from the eye to the ear opening; rostral moderate with a long median cleft behind; nostril between rostral, first supralabial, a large supranasal and two small postnasals; supranasal separated from its fellow on the opposite side by a single roughly hexagonal scale about two thirds the size of one of the supranasals, the three bordering the rostral above; four large and two small supralabials to below the centre of the eye; a spine on the superciliary margin over the centre of the eye; head above and on sides with extremely minute granular scales; scales of the snout distinetly enlarged and flattened; scales on back very large (comparatively speaking), heavily keeled, imbricate, giving a rough appearance; about seven in the distance from the tip of snout to ear; the change from the cephalic granules to the large dorsal scales is gradual; a very narrow median zone of very small scales, most conspicuous on the nape and shoulder region; mental large, larger than rostral; two very large infralabials and two very small ones to below the centre of the eye; two small, slightly elongate chin shields behind the mental, followed by small flat scales which gradually become the tiny scales of the midgular region; scales of chest and throat rounded, imbricate, smooth, rather large, not however as large as the dorsals; scales of limbs much smaller, imbricate, smooth or feebly keeled; scales of tail small, rounded, slightly elongate, imbricate, smooth, a rather inconspicuously enlarged series on the lower median surface of the tail.

Colour (in fresh specimen):- Uniform iron-gray above, pale below in the male, and in the female the ground-colour is bluish or stone-gray crossed on the nape, shoulders, and body by pairs of black bands; between these pairs of bands there are also cross-series of dark dots. In the young the pairs of bands are broad and conspicuous but the intermediate series of dots are absent.

$\begin{aligned} \text { Dimensions: - } & \text { Total length } \\ & \text { Tip of snout to vent } \\ & \text { Vent to tip of tail } \\ & \text { Greatest width of head } \\ & \text { Tip of snout to ear } \\ & \text { Fore limb } \\ & \text { Hind limb }\end{aligned}$

$58 \mathrm{~mm}$.

$32 \mathrm{~mm}$.

$26 \mathrm{~mm}$.

$5 \mathrm{~mm}$.

$7.5 \mathrm{~mm}$.

$8 \mathrm{~mm}$.

$11 \mathrm{~mm}$. 
The type-series of scaber has been compared with the types of picturatus from Jeremie, Haiti, and other recently taken examples also from Haiti. It may be separated by several characters. The Haitian species evidently grows much larger, in examples of similar size and the scales of the sides of the back are also larger and more strongly keeled. In picturatus too the shoulders (in the female) usually, if not always, bear a conspicuous spectacle-marking and the ground-colour is reddish instead of bluish. In general appearance they are very different but as is so often the case with related species of Sphaerodactylus it is very difficult to describe the various separating characters without over-emphasizing their individual importance.

The species evidently occurs in the Sierra de Jatibonico where Brown found it in 1918 and in the Sierra de San Juan de los Perros to the north of the Sierra de Jatibonico but still in sight of the main range in the western part of the Province of Camaguey. The senior author found six specimens all in deep woods under stones or decaying vegetation. The sexual dichromatism in this species and picturatus does not seem to have been previously emphasized, but is very striking. This is the species which Gundlach (Erpet. Cubana, 1880, p. 61) called S. fantasticus and which he said he found only at La Fermina near Bemba, now Jovellanos in the Province of Matanzas. For evidence that fanlasticus is confined to the island of Guadeloupe see Barbour, (Proc. Biol. soc. Wash., 1915, 28, p. 72).

IGUANIDAE.

22. Chamaeleolis chamaeleontides (Duméril \& Bibron).

Plate 14, fig. 2, 3.

Chipojo; Camáleón blanco; Camalcón ceniciente; Chipojo blanco; Chipojo $\operatorname{pardo,} d i c$.

Diagnosis:- A large gray arboreal lizard; the head with an elevated casque posteriorly; the whole body covered with flat, soft scales of very unequal size.

Description:- Adult M. C. Z. 8,759. Cuba: Oriente; Jiguaní, Los Negros, Spring of 1913. Thomas Barbour.

Head large, twice as long as broad; raised posteriorly in a casque-like manner; upper surface of head concave, covered with many rough tubercles, largest on the canthus rostralis; nostril near the tip of the snout; eye aperture small, ear aperture also small, vertically oval, a small dermal process above it. 
Gular scales minute and granular; double row of small triangular lobes on the chin; gular appendage very large, extending posteriorly to the thorax. Body strongly compressed. Dorsonuchal crest continuous with the posterior border of the casque. Body above and on the sides covered with round flat scales of irregular shape and size separated by areas covered with similar but very much smaller scales; ventral region with minute granules. Limbs rather short, the hind limb being extended forward along the body reaches only to the axilla; digits strongly dilated. Tail compressed, about as long as head and body, covered with irregular sized scales and below with smaller keeled ones.

Colour (in life):- Grayish varying to various shades of brown, never very dark, sometimes yellowish. The colour usually not uniform but variously marbled or blotched. The gular appendage is rosy, slightly purplish, with darker spots and streaks in the upper portion.

Dimensions: - Total length
Tips of snout to vent
Vent to tip of tail
Width of head
Fore leg
Hind leg

$326 \mathrm{~mm}$.

$138.5 \mathrm{~mm}$.

$187.5 \mathrm{~mm}$.

$19.2 \mathrm{~mm}$.

$57 \mathrm{~mm}$.

$73 \mathrm{~mm}$.

This remarkable lizard of a very distinct monotypic genus is wholly confined to Cuba. It occurs in all parts of the Island where there are forests both in lowlands and highlands. We have seen or collected specimens at Aguada de Pasajeros, vicinity of Manzanillo, Los Negros in Jiguani, La Maya near Alto Songo, and about Guantanamo. There is a specimen in the M. C. Z. from near San Diego de los Baños in western Cuba. The species is rare everywhere and is one which is universally feared by the natives, who believe it to be very venomous. Of the breeding habits of this lizard nothing is known. The only young examples which have been recorded were two taken by the junior author at La Maya, and "El Corojo" de San Carlos, Guantanamo, and a very young one taken during its first shedding, its umbilical area scarcely closed, by the senior author in October, 1918, on the Sierra de Anáfe near Guayabal, Havana Province. The second mentioned young example which is about $3 \frac{1}{4}$ " from snout to vent has a series of barbel-like scales, soft and almost hair-like, extending from the symphysis of the lower jaws to the origin of the dewlap. In all respects they are similar to the adults except that the head is markedly Anolis-like and lacks the casque-development with its characteristic ornamenta- 
tion of tubercles. It is a curious and noteworthy fact that the young of this species and of the Camaleon or Chipojo Verde (Anolis equestris) are very rarely seen and a naturalist may secure many adults without seeing a single immature example. This is certainly true with the Venus Lizard of Jamaica (Anolis garmani) which has frequently been observed and collected by one of the authors (Barbour). In so far as we are aware the young of the related species in Haiti and Porto Rico (Anolis ricordii and A. cuvieri respectively) are entirely unknown.

\section{Deiroptyx vermiculatus (Duméril \& Bibron).}

Plate 14, fig. 4.

Caiman, (Guane and the Valley of Luis Lazo); Lajartija (elsewhere).

Diagnosis:- A pale gray, white barred, depressed Anolis-like lizard, having a transverse fold across the throat in place of a dewlap.

Description:-Adult M. C. Z. 10,847. Cuba: Pinar del Rio; Valley of Luis Lazo, Banks of Rio Cuyaguateje, March, 1915. Thomas Barbour.

Head long and depressed similar to but slightly wider than in Anolis porcatus; top of head covered with flat, rather uniform, small scales; frontal ridges very weakly developed, barely discernible; supraocular semicircles with second scale from anterior end very large, separated by two rows of flat scales; occipital in a depression, small, scarcely one sixth as large as ear opening; supraocular dises well defined, composed of about eight rather large and a few smaller scales, separated from the semicircles by two rows of scales; canthus rostralis not especially prominent composed of one large scale near the eye and then a double row of very small scales extending to just below the nostril; a superciliary ridge of two or three very long scales; loreal rows, about eight; subocular semicircles represented by but about three scales in contact with the supralabials; eight supralabials, the seventh under the centre of eye; temporals small, round and flat, uniform in size; no supratemporal line; dorsal scales slightly larger than laterals, the two middorsal rows largest; ventrals larger, squarish, in regular rows, slightly imbricate; scales of anterior aspect of fore and hind limbs slightly enlarged, imbricate but not keeled; body rather elongate, depressed; no nuchal nor dorsal fold; limbs long, hind limbs very long; the adpressed hind limb reaches almost to the nostril; about thirty lamellae under phalanges II and III of the fourth toe; tail rather long, round, with verticils feebly indicated at about eleven scale intervals; postanal scales not enlarged; a transverse gular fold. 
Colour (in life):- Usually ashy gray variously striped with darker and lighter; a series of vertical white lines frequently present upon the flanks. The colour may change to brown of varying intensity with white or gray vermiculations. Lower surfaces white.

$\begin{array}{lr}\text { Dimensions: - Total length } & 198 \mathrm{~mm} . \\ \text { Tip of snout to vent } & 70 \mathrm{~mm} . \\ \text { Vent to tip of tail } & 128 \mathrm{~mm} . \\ \text { Width of head } & 12 \mathrm{~mm} . \\ \text { Fore leg } & 33 \mathrm{~mm} . \\ \text { Hind leg } & 58 \mathrm{~mm} .\end{array}$

By most authorities this lizard has been included in Anolis but a careful examination of the cephalic squamation reveals many very peculiar characteristics, while the transverse gular fold in place of the dewlap is in itself a character of full generic value. The genus Deiroptyx, then, erected by Fitzinger (Syst. Rept., 1843, p. 66) and based upon this species alone, becomes available for use as noted by Stejneger (loc. cit., p. 268).

No Cuban lizard has more interesting and unusual habits than has this one. While it is not remarkable to find it upon outcrops of limestone rocks at some distance from water, yet this is not its characteristic habitat. It usually frequents the boulders and tree-trunks along water courses of considerable size and when disturbed it springs at once into the water there to dive and swim actively below the surface, and to hide in some nook or cranny until the danger has passed. It can run upon the surface of the water after the manner of many other iguanids, notably Basiliscus, Laemanctus and some species of Anolis. Its form, resembling a miniature Caiman as well as its readily taking to water, have given it its common name in part of western Pinar del Rio.

Deiroptyx vermiculata is not widely distributed in Cuba. It has a limited range, apparently within the western Province of Pinar del Rio. Gundlach observed it only on the banks of the Rio Taco Taco and the Rio Santa Cruz. Palmer and Riley while collecting for the U. S. National Museum in 1900 found it abundant about streams near San Diego de los Baños. The various trips of the senior author made in recent years with Prof. Carlos de la Torre, Mr. IV. S. Brooks, Senor V. J. Rodriguez, and others has yielded a number of specimens from Mendoza, Guane, the Valley of Luis Lazo, Sumidero, and other localities in the extreme western districts of the Island. 


\section{Key to the Species of Anolis.}

a ${ }^{1}$ Head elevated posteriorly into a rugose casque . . . . . . . . . equestris, p. 133

$a^{2} \quad$ Head normal in shape.

b) Canthal scales projecting, flange-like, head long, depressed, rugose above . $\checkmark$ porcatus, p. 163

1) ${ }^{2}$. Canthal seales normal, head more or less smooth above.

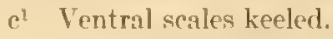

$d^{1} \quad$ Ventral scales strongly keeled.

$e^{1}$ Habit excessively slender, head very narrow, body no wider

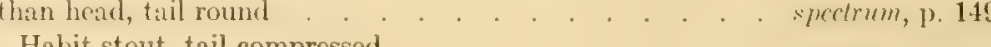

$a^{2} \quad$ Habit stout, tail compressed.

$f^{1} \quad$ Head short, frontal ridges separated by but one or two scales . . . . . . . .. . . . Vgreyi, p. 144

$\mathrm{f}^{2} \quad$ Frontal ridges usually separated by more than one or two scales.

$\mathrm{g}^{1}$ Dewlap in male very large, maroon in colour, head slightly elongate . . . . . . . bremeri, p. 144

$\mathrm{g}^{2}$ Dewlap moderate in size, burnt orange in colour,

head short . . . . . . . . . vsagrei, p. 142

$d^{2}$ Ventrals feebly keeled, tril round, slender but not excessively

so, green . . . . . . . . . . . . . . . veyanopleurus, p. 150

$c^{2}$ Ventral scales smooth.

$d^{3}$ Tail round.

$\mathrm{e}^{1}$ Body with scattered spine-like scales. . . . . . . Joysiana, p. 146

$\mathrm{c}^{2}$ Body without scattered spine-like scales.

$\mathrm{f}^{1}$ Habit excessively slender, head elongate, dark brown . $\checkmark$ alutaceus, p. 153

$f^{2} \quad$ Habit not excessively slender.

$\mathrm{g}^{1}$ Head flat, with scales irregularly arranged, mosaic-like and flat . . . . . . . . . . . visolepis, p. 137

$\mathrm{g}^{2} \quad$ Head with scales regularly arranged.

$h^{1}$ Head with scales of semicircles kecled and separated by but one row of scales, body depressed. . . . . . . . vangusticeps, p. 135

$h^{2}$ Head with scales of semicircles smooth, broadly in contact.

$i^{1}$ Habit very stocky, tail but little longer than head and body, round, body longitudinally striped . . . . . . . argitlaceus, p. 147

$\mathrm{i}^{2} \quad$ Habit more elongate, normal, tail longer.

$j^{1}$ Semicircles composed of large seales, broadly in contact, head twice as long as broad ...... vargenteolus, p. 140

$\mathrm{j}^{2} \quad$ Semicircles composed of large scales, broadly in contact, but head only once and one half times as long as broad . lucius, p. 138

$d^{2}$ 'lail not cylindrical.

$\mathrm{e}^{\mathrm{l}}$ 'Tail compressed but without a "fin,"' very many small

kecled scales upon the snout . . . . . . . . . . . 'mestrei, p. 161

$\mathrm{c}^{2} \quad$ Tail with a more or less well-developed "fin."

$\mathrm{f}^{1}$ Tail with a moderately-developed "fin," many small

keeled scales upon the snout . . . . . . . Jallogus, p. 159

$f^{2}$ Tail with a high "fin."

gl Frontal ridges separated by about five rows of

kceled scales . . . . . . . . rubribarbus, p. 156

$g^{2}$ Frontal ridges separated by one or two rows of seales.

$h^{1}$ About ten smooth supralabials, dewlap white homolechis, p. 155

$h^{2} \quad$ About seven smooth supralabials, several large dark markings on each side, surrounded by white dots . . . . . . . . . quadriocellifer, p. 158 


\section{Anolis Equestris Merrem.}

Plate 14, fig. 5.

\section{Camaleón; Camaleón verde; Chipojo.}

Diagnosis: - A large, usually green, lizard with the upper surface of the head developed into a casque, studded with rough tubercles, also with a greatly developed gular pouch which in life is a vivid chrome-yellow.

Description:-Adult M. C. Z. 7,906. Cuba: Madruga, Spring of 1910. Thomas Barbour.

Head large, top of head flat, with extensive depressions on prefrontal and occipital region; the scales of the latter area being small and roughly tuberculated, while those on the snout are larger and much more heavily corrugated; a group of flat plate-like scales on each supraorbital region; supraorbital semicircles prominent thin laminar scales set side by side, their long axes parallel; the circles separated by three or four rows of small tubercular scales; the series of scales forming the supraorbital semicircles continued posteriorly into ridges of prominent scales which surround the occipital depression; canthal scales much enlarged and very heavily tubercular; five or six loreal rows, the scales of the rows next to the supralabials the largest; one row of large suboculars, the posterior two of which are keeled; ten supralabials to below the centre of the eye; temporals flat; ear opening small, round, back and sides covered with uniform flat or slightly swollen scales which are separated from each other by a narrow zone of soft skin, many of the scales tend to a rounded form; on the median line of the neck and back a series of spine-like scales forming a weak nuchal and dorsal crest which is continuous on the sacral region with caudal crest; ventral scales smooth and tending to imbricate smaller than the scales on the sides; scales on fore and hind limbs smooth and pavement-like; digital expansions greatly developed, about thirty-seven lamellae under second and third phalanges of the fourth toe; tail strongly compressed with a caudal crest similar to the dorsal; gular appendage very large, with distinet rows of small flat scales on the naked skin, the edge rounded, thickened and scaly; no enlarged preanal plates.

Colour (in life):- Uniform emerald-green; sometimes changing to brownish or even almost black; sometimes with vertical brown bars on the sides of the body, the ground-color being green. A yellowish streak beginning above 
the insertion of the fore limb and extending for about one third the length of the side is a fairly permanent feature. Dewlap yellow in life, sometimes changing to pinkish in alcohol.

$\begin{aligned} \text { Dimensions: - } & \text { Total length } \\ & \text { Tip of snout to vent } \\ & \text { Vent to tip of tail } \\ & \text { Width of head } \\ & \text { Fore leg } \\ & \text { Hind leg }\end{aligned}$
$444 \mathrm{~mm}$.
$141 \mathrm{~mm}$.
$303 \mathrm{~mm}$.
$21 \mathrm{~mm}$.
$57 \mathrm{~mm}$.
$94 \mathrm{~mm}$.

The adults of this species do not vary much inter se. A most astonishing series of changes in form takes place, however, during the growth of the individual. The half-grown and young, owing to their usually appearing in the vivid green dress and apparently remaining in the tree-tops all the time, are extremely difficult to find; especially since the species is far from abundant in the most favorable localities. We have in the M. C. Z. three choice immature examples, one from Santiago (Wirt Robinson coll.), one from San Diego de los Baños (Barbour coll.) and one from the woods at Rio Seco near San Carlos, Guantanamo (Ramsden coll.). All of these are smaller than any recorded and the example last mentioned is very young, the umbilicus being but incompletely closed. This specimen measures but $40 \mathrm{~mm}$. from snout to vent, while the tail is $96 \mathrm{~mm}$. long. The other two examples are about twice this size, but one has a pattern of colouration similar to that which we shall describe, while the other was uniform green. This specimen is brilliant green with four white bands crossing the body, their ends on each side being joined by a white lateral line. There is a white stripe along the upper lip and the dewlap in life was olive-green. On the surface of the head all the scales are quite flat and smooth, but nevertheless their arrangement and distribution is in perfect conformity with the condition seen in the adults, and there can be no doubt as to all our specimens being conspecific. The capture of these specimens also makes it quite certain that we were not failing to recognize the young of the species and were calling it by another name, as has been thought possible. This species attains the largest size of any member of the genus, reaching a length of about $50 \mathrm{~cm}$.

Like the other giant Anoles of Jamaica, Haiti, and Porto Rico, the adults of the Cuban form though far from common may still be quite easily found by searching in orchards, especially of mango trees and in groves of palms. The young probably remain hidden in the dense foliage of the tree-tops to escape 
the smaller birds of prey. In Cuba the local sparrow hawks subsist almost entirely on lizards and might catch these young arboreal lizards more easily than species of the same size living near the ground. The adults are agile and capable of biting fiercely. They too are seldom or never seen near the ground, possibly descending for oviposition, although the eggs may be laid in hollow trees.

The natives have a very widespread belief that the bite of this species is dangerous, the victim being at once seized with fever and ague. As to the food of the great Anolis we know but little; it is surely insectivorous and Gündlach records that he once heard the shrill seream of a tree frog (Hyla) and found that it had been caught by one of these lizards. The country people all declare that they feed largely upon fruit, especially the mango; it is not improbable that this idea arises from the fact that they are frequently found in mango trees. We have always imagined that this circumstance was due in part at least to the excellent cover offered by the splendid growth of rich green foliage of the Cuban mango trees; it, however, has been seen eating berries (Ramsden). With good luck one may occasionally see two males of this fine species chasing one another about, making short rushes and charges at each other, accompanied by much tossing of heads and display of brilliant dewlaps. When this mimic battle takes place about the smooth green top of the trunk of a stately Royal Palm, it is a sight not easily forgotten.

The Giant Anolis occurs throughout the whole Island and, unlike the Gray Chipojo, is not confined to the virgin forest, but apparently prefers groves and orchards. Its abundance is probably not being affected by the extensive deforestation which is taking place in so many parts of the Island.

\section{5." Anolis angusticeps Hallowell. \\ biti 7 ; Fin.l \\ Lagartija.}

Diagnosis: - A depressed rather slender Anolis having a long and rather flat head; short limbs; gray in color, variously mottled or longitudinally striped, with a peach-pink dewlap.

Description:- Adult ơ M. C. Z. 7,956. Cuba: Santa Clara Province; region of Sierra de Jatibonico, 1912. Barnum Brown.

Top of head with two ridges of keeled scales enclosing a slightly depressed oval area; ridges converging gradually and meeting just posterior to the nos- 
trils; oval depression paved with about six flat polygonal scales; head-scales generally flat or slightly rugose; about five scales in a row between the nostrils; supraocular semicircles separated by one row of flat scales; occipital larger than ear opening, just in contact with the semicircles; supraocular disc composed of two or three large scales and a few smaller ones, separated from the semicircles by a single row of very small scales; canthus rostralis distinct and prolonged from under nostrils to just over anterior border of eye, of about seven long scales; no superciliary ridge; loreal rows, three; subocular semicircles indistinct, being really only the backward continuation of the lower loreal row; about nine smooth supralabials, the eighth being about under the centre of the eye; temporals small and flat, the central group smallest, a very faintly indicated supratemporal line; scales of back, sides, and belly all smooth, small and almost uniform, the ventrals having a tendency to imbricate; scales of anterior aspect of lower arm and hind limb enlarged, flat and strongly imbricating; body elongate and rather depressed; no nuchal nor dorsal fold; limbs short, the adpressed hind limb reaches the shoulder; about twenty lamellae under phalanges II and III of the fourth toe; tail rather long, almost round, with weakly indicated verticils for the greater part of its length, these separated by about six vertical series of keeled scales, the limiting row distinctly enlarged; postanal scales considerably enlarged.

Colour (in life):- (Specimen from Guane) light yellowish or grayish often with light lateral bands and with slightly darker dorsal rhombic markings, throat flecked with darker; whole upper surface often covered with anastamosing wavy lines; lower part white; dewlap skin peach-blow pink, the seales white and the edge ashy gray.

$\begin{array}{lr}\text { Dimensions:- Total length (an adult from the Island of Pines) } & 114 \mathrm{~mm} . \\ & \text { Tip of snout to vent } \\ \text { Vent to tip of tail } & 73 \mathrm{~mm} . \\ \text { Width of head } & 6 \mathrm{~mm} \text {. } \\ \text { Fore leg } & 13.5 \mathrm{~mm} . \\ \text { Hind leg } & 23 \mathrm{~mm} \text {. }\end{array}$

Though this species was very inadequately described, it is distinct and seems to be the western Cuban representatives of Anolis isolepis, as A. lucius is of $A$. argenteolus. Thanks to Mr. H. W. Fowler, Hallowell's type has been examined and photographed. Since the type came from Cienfuegos an adult male from the Jatibonico range, Santa Clara Province, was chosen for descrip- 
tion, although lacking part of its tail. Mr. R. M. Grey has since sent the M. C. Z. a fine adult female from Soledad, near Cienfuegos, so that a topotype recently taken could also be compared with the type. The species is not uncommon about Guane and Luis Lazo and on the Island of Pines (Barbour). In the Island of Pines especially, it seems to frequent the trunks of Royal Palms, with the colour of which it blends beautifully. At Guane we found it principally in the thick "manigua" or serub generally upon white or gray rocks.

\section{ANOlis ISOlepis Cope.}

Plate 7, fig. 2.

\section{Lagartija.}

Diagnosis: - A very small, compressed, short limbed, thickset Anolis, cross banded with dark mauve upon a very light mauve-ground. Entirely covered above and below with tiny uniform scales. Dewlap apricot-yellow; head without frontal ridges.

Description:-Adult? or M. C. Z. 8,514. Cuba: Oriente; Jiguaní, Los Negros, (High Sierra Maestra), 1913. Thomas Barbour.

No frontal ridges, top of head covered with plate-like scales with many parallel striae; all head-scales striate, none carinate; only three or four rather large scales between the nostrils; supraocular semicircles separated by but one row of large striate scales; supraocular dises ill defined, the whole supraocular area covered with plate-like scales of varying size and hardly distinguishable from the semicircles; canthus rostralis composed of three or four seales, the anterior largest, projecting backward to form a short supraorbital ridge; loreal rows, three; subocular semicircles of rather large kecled scales, one behind and below the eye large, semicireles broadly in contact with the supralabials; eight or nine smooth supralabials, the suture between the seventh and eighth below the centre of the eye; oceipital not much enlarged, about the size of the ear opening and similar in character to the surrounding scales; temporals rather large, flat and polygonal; seales of back, sides, and belly all very small, the belly-scales and the dorsals a little smaller than those on the sides, bellyscales perfectly smooth and slightly imbricate; scales upon anterior aspects of the limbs not enlarged nor imbricating; body stout, compressed; no nuchal nor dorsal fold; digits of hind limb short; the adpressed hind limb reaches but very slightly beyond the axilla; digital expansions very little developed, about 
fifteen lamellae under phalanges II and III of the fourth toe; tail short, cylindrical, covered with small uniform keeled, imbricating scales, no verticils; postanal plates scarcely if at all enlarged.

Colour (in life): - Light mauve-gray with stripes of darker upon the sides of the head and irregular cross-bars upon the back and tail, sides with scattered blotches and fine scattered dark dots on the ventrolateral region. Belly bluish white, throat and under side of tail spotted. Dewlap apricot-yellow.

$\begin{array}{cr}\text { Dimensions: - Total length } & 64 \mathrm{~mm} . \\ \text { Tip of snout to vent } & 28 \mathrm{~mm} . \\ \text { Vent to tip of tail } & 36 \mathrm{~mm} . \\ \text { Width of head } & 6 \mathrm{~mm} . \\ \text { Fore leg } & 10 \mathrm{~mm} . \\ \text { Hind leg } & 14 \mathrm{~mm} .\end{array}$

This species is a rare denizen of the deep mountain forests. It is very beautiful in life. The type came from the Sierra de Yateras. It has been found upon Monte Libano and at Belona (Ramsden). These with the example described are the only specimens known with definite data.

\section{Anolis Lucius Duméril \& Bibron.}

Plate 6, fig. 4.

\section{Coronel.}

Diagnosis: - A rather large, long limbed Anolis, ashy gray in colour, with a dark chevron-like band upon the nape and a pure white occipital spot.

Description:-Adult ơ M. C. Z. 8,496. Cuba: Matanzas, Abra del Rio Yumurí, 1913. Thomas Barbour.

Top of head with two slightly converging ridges, enclosing a rather deep trench-like depression; about six small scales between the ridges where they are farthest apart; head-scales, some smooth, some rough or some rather distinctly keeled; eight or nine scales in a row between the nostrils; supraocular semicircles broadly in contact, with large median scales; occipital about two thirds size of ear opening, separated from the supraocular semicircles by two or three rows of small flat scales; supraocular disc consisting of about ten enlarged flat, polygonal scales, separated from the semicircles by three rows of very small scales; canthus rostralis consisting of five elongate, prominent scales, continued posteriorly they form a superciliary ridge which extends to over the 
centre of the eye; loreal rows, six; subocular semicircles of rather large, squarish feebly keeled scales, scarcely in contact with supralabials, not more than two seales in contact; nine smooth supralabials, the seventh under the centre of the eye; temporals very minute, smallest in centre of temporal area; no supratemporal ridge; no enlarged dorsal scales; back and sides covered with very small, flat, almost circular scales; ventrals larger, also rotund, non-imbricating; a few rows of larger slightly imbricating scales on anterior aspects of limbs; seales on digits smooth; digits of hind limb moderately long, with well-developed expansions; about twenty-five lamellae under phalanges II and III of fourth toe; gular pouch rather well developed in the male, not in female; body not compressed; no nuchal nor dorsal fold; the adpressed hind limb reaches almost to the nostril, tail long, slightly compressed; with verticils on the proximal portion very slightly indicated, separated by about twelve or thirteen series of scales; male with slightly enlarged postanal scales.

Colour (in life):- Ashy gray, a light streak along the side of the head, several chevron-like bands across nape and back, the back and upper surface of tail with varying dark cross-bands and blotches; limbs faintly cross banded; lower surfaces, whitish or greenish; dewlap light greenish gray.

$\begin{array}{cr}\text { Dimensions: - Total length } & 180 \mathrm{~mm} . \\ \text { Tip of snout to vent } & 63 \mathrm{~mm} . \\ \text { Vent to tip of tail } & 117 \mathrm{~mm} . \\ \text { Width of head } & 10.5 \mathrm{~mm} . \\ \text { Fore leg } & 31 \mathrm{~mm} . \\ \text { Hind leg } & 54 \mathrm{~mm} .\end{array}$

The Coronel, as this lizard is called about Matanzas on account of its military striping or chevron-like bands, is locally abundant. It is found only in the vicinity of limestone cliffs and is usually seen crawling about on the rocks at the entrances of the caves so common in these regions. Only rarely is it found on the trunks of trees and then only on those which grow upon the paradones. About Matanzas A. lucius is particularly abundant, on account of the great limestone caves in the cliffs where the Yumuri River has gradually cut its way down to its present level. The local peasants believe that the scattered calls which one hears at night coming from the cliffs of the Abra or gorge of the Yumuri are made by the Coronel; in reality they are the call of an Eleutherodactylus. Curiously in the Valley of Luis Lazo the same tinkly belllike calls are locally supposed to be made by the Iguana de la Sierra, a Leio- 
cephalus. The distribution of $A$. lucius is rather limited. Gundlach found it at Matanzas and the San Miguel hills near Coliseo, and it has been taken also at Madruga and near Aguacate (Barbour). Barnum Brown collected an example now in the M. C. Z., in the Sierra de Jatibonico in Santa Clara. The species extends much farther eastward than we had previously supposed, for it has been taken near Cienfuegos, at Guaos, in February 1917 (Barbour) and Rodriguez has sent us a typical example from Guaimaro, in the Province of Camaguey.

28. Anolis argenteolus Cope.

Plate 14, fig. 6.

Lagartija; Lagartijo de Tablado, (Santiago).

Diagnosis:- A slender, long limbed, long tailed, ashy gray Anolis, having a very large eye and a flat almost spatulate rostrum.

Description:-Adult or M. C. Z. 7,438. Cuba: Santiago, The Plaza, 1909. Thomas Barbour.

Related to Anolis lucius from which it may be easily distinguished by its form and colouration. It is much more slender, having a head twice as long as broad; instead of one and one half times as in lucius; the snout much more depressed; the white occipital spot and the conspicuous white head-band and the brown chevrons are wanting in argenteolus.

Top of head with two slightly developed ridges, enclosing, however, a sharply depressed oval area; head-scales smooth or feebly keeled; about eight scales in a row between the nostrils; supraocular semicircles very broadly in contact, the whole median part of each semicircle being composed of a pair of great plate-like scales; supraocular semicircles consisting of six or seven flat scales; barely separated from the semicircles by a row of minute granules; occipital as large as ear opening and in contact with the semicircles; canthus rostralis scarcely indicated, consisting of four or five slightly enlarged scales, continued posteriorly it forms a weak superciliary ridge to above the centre of the eye; loreal rows, seven; subocular semicircles of elongate strongly keeled scales broadly in contact with supralabials; seven smooth supralabials, the suture between the sixth and seventh about under the centre of the eye; temporals minute; a very indistinctly defined supratemporal line; whole of back and sides covered with minute flat scales, almost granular; ventral scales larger, squarish or rotund, non-imbricating; scales on anterior aspects of limbs 
enlarged and imbricating; on digits imbricating and smooth; body depressed; a very feeble nuchal, no dorsal fold; limbs long, the adpressed hind limb reaching to between the large eye and the nostrils; digits of hind limb long, expansions well developed, about nineteen lamellae under phalanges II and III of the fourth toe; tail long, almost round, covered with small keeled scales; verticils on the proximal portion only very feebly indicated, separated by about seven series of scales; postanal plates very slightly enlarged.

Colour (in life):- Ashy gray or grayish brown, irregularly mottled with darker gray or brown; a white crescentic line under eye; limbs without crossbars; dewlap greenish white.

$\begin{array}{cr}\text { Dimensions: - Total length } & 161 \mathrm{~mm} . \\ \text { Tip of snout to vent } & 54 \mathrm{~mm} . \\ \text { Vent to tip of tail } & 107 \mathrm{~mm} . \\ \text { Width of head } & 8 \mathrm{~mm} . \\ \text { Fore leg } & 25 \mathrm{~mm} . \\ \text { Hind leg } & 56 \mathrm{~mm} .\end{array}$

On the throat of the female of both this species and $A$. lucius there are brown longitudinal lines.

Anolis argenteolus is another species which is very partial to the gray limestone cliffs, where, like lucius, its colour affords remarkable protection. It is, however, much more often than with that species found upon the trunks of trees or upon the sides of buildings but usually only when they are near outcroppings of limestone rock. 'The one chosen for description was taken upon one of the "Spanish laurel" trees in the Plaza opposite the Cathedral in the city of Santiago. The species is confined to Oriente Province, so far as now known, but unlike lucius it has a considerable range. We have taken it in the mountains about Guantanamo; it is also found at San Luis, at Los Negros and Bueycito in the Sierra Maestra, at Cabo Cruz and Belig (Barbour), and at various points near Baracoa (de la Torre and V. J. Rodriguez). Thus it ranges widely in Oriente but has not been taken outside of the Province. Strange to say it is not found in the city of Guantanamo although it is very common in the cemetery and on the back yard walls of Santiago. This is the only species of Anolis which is found so near civilization and in the deep forest as well. Anolis porcatus and A. sagrei apparently occur now only in cultivated or abandoned fields.

Boulenger (Cat. lizards Brit. mus., 1885, 2, p. 45) confused this species 
with $A$. lucius. It is not improbable that the remarks which he makes regarding the difference between males and females in that species really indicate that he had both forms. He rarely gives more than "Cuba" for the locality of any of his Cuban specimens, and the specimen of Anolis cyanopleurus which he so kindly loaned bore this information only. Very probably lack of data, poor preservation, and the very small number of specimens available in the British Museum from Cuba, account for his confusion of these and other local species.

\section{Anolis sagrei Duméril \& Bibron.}

Plate 14, fig. 7.

\section{Lagartija comun; Chino (Havana).}

Diagnosis:- A stout bodied Anolis, with an uncrested tail, with heavily keeled ventrals and with the dewlap skin orange-red, the scales black, and the edge lemon-yellow.

Description:-Adult o7 M. C. Z. 8,559. Cuba: Havana, El Jardin Botanico del Institúto de Segunda Enseñanza, March, 1913. Thomas Barbour.

Top of head with two well-bowed ridges, not closely converging anteriorly, at a point about halfway between eye and nostril the ridges separated by four scales; head-scales either keeled or strongly rugose; about six scales in a row between the nostrils; supraocular semicircles separated by one row of keeled scales; occipital rather small, in a depressed area, about half the size of ear opening; separated from the semicircles by three or four small but strongly keeled scales; supraocular dises well defined composed of five or six large and a number of lesser scales, some almost flat, some weakly keeled, dises separated from the semicircles by a row of small scales; canthus rostralis distinct, composed of about three very elongate scales, two long scales overlapping form a superciliary ridge reaching to about the middle of the eye; loreal rows, four; the lower loreal row is enlarged and passes backward below the eye in contact with the supralabials, so that there is no true subocular semicircle; about five large smooth supralabials, the fourth under the eye; temporals keeled, those of the central temporal area very small, almost granular; a faintly indicated supratemporal line; scales of back and sides keeled, about eight middorsal rows enlarged, more strongly keeled and more imbricating; ventrals larger than the largest dorsals, imbricating and strongly keeled, the keels continuous; scales of anterior aspects of fore and hind limbs slightly larger than the ventrals, strongly keeled and imbricating; body stout, rather compressed; a very faint 
nuchal and anterior dorsal fold, capable, however, of more extended voluntary elevation in life; limbs medium short, digits well dilated, the adpressed hind limb reaches to the posterior border of the orbit; about sixteen lamellae under phalanges II and III of the fourth toe; tail rather long, strongly compressed with very indistinct verticils, separated by about five rows of scales; the limiting rows but slightly enlarged; no "fin" upon tail; postanal scales slightly enlarged.

Colour (in life): - Very varied in the fully adults, usually black or brown more or less uniform, pale below; the dewlap skin brick-red with black scales and a yellow margin. In young lizards there is generally either a light band along the back or a series of more or less distinet separated or confluent pale rhombic markings.

$\begin{array}{cr}\text { Dimensions: - Total length } & 165 \mathrm{~mm} \text {. } \\ \text { Tip of snout to vent } & 61 \mathrm{~mm} \text {. } \\ \text { Vent to tip of tail } & 104 \mathrm{~mm} \text {. } \\ \text { Width of head } & 10.5 \mathrm{~mm} \text {. } \\ \text { Fore limb } & 25.5 \mathrm{~mm} \text {. } \\ \text { Hind limb } & 46 \mathrm{~mm} \text {. }\end{array}$

In this species as well as the two following the males have a markedly developed, erectile nuchal fold which is extended simultaneously with the expansion of the dewlap.

This is the common lizard of the roadside fences and garden walls. It is excessively abundant, one of the commonest lizards in the world where it occurs. It is usually found in the lowlands and it is very rare or entirely absent in the more thickly forested areas. It is found all over Cuba but far more abundantly in the Provinces of Havana and Pinar del Rio than elsewhere for here cultivation has cleared the face of the countryside more than in the less densely populated Provinces of Camaguey and Oriente.

Anolis sagrei occurs upon the hot dry coastal plain near Kingston, Jamaica, whence the U.S. N. M. has received specimens some of which are now in the M. C. Z. The senior author did not find it when collecting about Kingston in 1909 and it may have been accidentally introduced. It is recorded by Boulenger from Belize and Caracas but these records are very unlikely and the specimens should be compared with topotypes from Cuba. In case they are the same further collecting is needed to show that we have not to deal with mistakes in labeling. The Belize record is possible but improbable, the Caracas record seemingly wholly impossible. 


\section{ANolis greyi Barbour.}

Plate 7, fig. 3.

\section{Lagartija.}

Diagnosis:- $-A$ heavy, stockily built Anolis very like $A$. sagrei but with larger head-scales and without the enlarged keeled imbricating middorsals.

Description:- TYPe. Adult ơ M. C. Z. 7,890. Cuba: Camagüey, April, 1909. Thomas Barbour.

Very similar to $A$. sagrei, distinguished by the almost perfectly homogeneous dorsal squamation; the larger and flatter scales about the occipital and the fetwer scales, only one or two, between the frontal ridges, which are more parallel, much less bowed than in $A$. sagrei. In $A$. greyi the head is flatter, more depressed, so that the profile is not so declivous as in $A$. sagrei.

Colour (in life): - Similar to sagrei but lighter. Dewlap colour unnoted.

$\begin{aligned} \text { Dimensions: - } & \text { Total length } \\ & \text { Vent to tip of snout } \\ & \text { Vent to tip of tail } \\ & \text { Width of head } \\ & \text { Fore leg } \\ & \text { Hind leg }\end{aligned}$

$$
\begin{array}{r}
152 \mathrm{~mm} . \\
57 \mathrm{~mm} \text {. } \\
95 \mathrm{~mm} \text {. } \\
9 \mathrm{~mm} \text {. } \\
25 \mathrm{~mm} \text {. } \\
39.5 \mathrm{~mm} \text {. }
\end{array}
$$

While collecting about the city of Camagüey in 1909 a few of these Anoles were secured in the garden near the Camagüey Hotel, among a large series of A. sagrei (Barbour). Dr. Carlos de la Torre in 1914 captured a small series, none adult, in the Sierra de Cubitas, north of the city, which we believe are referable to the same species. Except for these few data, merely the facts that the species occurred with sagrei and frequented cultivated gardens, nothing is known regarding its habits nor distribution. We have both searched for it in vain on subsequent visits in the exact type-locality.

\section{Anolis bremeri Barbour.}

Plate 6, fig. 5.

Lagartija.

Diagnosis:- A mottled grayish or brownish Anolis, distinguished by an enormously developed dewlap of rich maroon-brown.

Description:- TYye. Adult ơ M. C. Z. 7,889. Cuba: Pinar del Rio; Herradura, February, 1912. Thomas Barbour. 
Top of head with two curved frontal ridges which converge anteriorly and inclose a shallow frontal depression; head-scales including those of the supraocular dise all strongly keeled; supraocular semicircles separated by a single row of scales, three of which are elongate and elevated to form a short median ridge; occipital about the size of the ear opening and separated from the supraocular semicircle by two or three rows of scales; supraocular dise composed of eight polygonal keeled scales, separated from the semicircle by a single row of very small granules, polygonal or elongate scales; canthus rostralis composed of few scales, one extremely elongated in the middle of the series, flanked by other less elongate on either side; superciliary ridge consisting of one very long anterior shield, followed by a number of much smaller seales; loreal rows, five; subocular semicircle strongly keeled; supralabials six, suture between fourth and fifth being about under centre of eye; temporal scales small and granular, bordered above by a rather irregular zone of enlarged scales, which extends from the posterior border of the orbit to a point some distance above the ear opening; dorsals small, flat, smooth, showing no tendency to imbricate, a median zone consisting of from three to four series of enlarged more or less distinctly keeled seales; this zone commenees at about the region of the fore limbs; ventrals much larger than dorsals, imbricate and distinctly but not strongly keeled; fore limbs above with rows of very strongly keeled and enlarged scales, similar scales present an anterior aspeet of thighs; subdigital expansions feebly developed consisting of about 18 lamellae under phalanges II and III of the fourth toe. Tail strongly compressed with about fifteen evident verticils along its proximal region; such verticil is separated by about seven vertical rows of keeled scales; upper edge feebly serrate, each segment with four small spines; dewlap very large and capable of great dilation, extending along the midventral line to a point considerably posterior to the line of the axillac; a very few feebly enlarged postanal seales; no dorsal fold.

Colour (in life):- Grayish or reddish brown, variously clouded or spotted with blotches and many bands of dark brown or black, belly pale ashy or greenish; dewlap fine lustrous maroon.

Dimensions: - Total length
Tip of snout to vent
Vent to tip of tail
Tip of snout to ear
Width of head
Fore leg
Hind leg

$143 \mathrm{~mm}$.

$58 \mathrm{~mm}$.

$85 \mathrm{~mm}$.

$17 \mathrm{~mm}$.

$10.5 \mathrm{~mm}$.

$26 \mathrm{~mm}$.

$46 \mathrm{~mm}$. 
Since the discovery of the type in February, 1912, no additional specimens have been reported. The lizard was found resting upon the thatched roof of a peasant's house several miles north of Herradura.

\section{Anolis loysiana (Cocteau).}

Plate 3, fig. 4; Plate 7, fig. 4.

\section{Lagartija.}

Diagnosis:- A small depressed grayish lizard, the sides of whose body and tail are closely beset with spine-like projecting scales; colour resembles closely a gray lichen.

Description:-Adult M. Z. C. 8,511. Cuba: Oriente; Jiguaní, Los Negros. Thomas Barbour.

Top of head with two ridges which first converge to enclose a shallow depressed area paved with five or six flat polygonal scales, then the ridges extend forward parallel and rather ill defined to near the tip of the snout; head-scales in general flat or slightly rugose; about five or six scales between the nostrils; supraocular semicircles in contact for at least half their extent; occipital about twice as large as ear opening, separated anteriorly from the semicircles by one large irregularly pentagonal scale; supraocular disc consisting of four transverse scales much longer than wide, separated from the semicircles by a double row of minute scales; canthus rostralis consisting of five or six strongly keeled scales diminishing in size anteriorly; loreal rows three; subocular semicircles composed of rather rough enlarged scales which are widely in contact with the supralabials; six or seven smooth supralabials, the sixth lying under the centre of the eye; temporals flat, polygonal, pavement-like, smallest in the centre but nowhere granular, no supratemporal line; two middorsal rows very slightly enlarged, not keeled; rest of back and sides covered with small flat scales, except for scattered protuberances covered with several scales, the apical one of which is strongly enlarged, conical and projecting; on the limbs and tail these projecting spine-like scales also occur abundantly; ventral scales small, flat and slightly imbricating; gular appendage small; the adpressed hind limb reaches the shoulder; digital expansions well developed; about twenty-four lamellae under phalanges II and III of the fourth toe; tail cylindrical, about as long as head and body; with an irregular dorsal series of enlarged imbricating scales, many scattered spine-like scales and no trace of verticils. 
Colour (in life):- Very light gray above with fine narrow cross-bands and anastomosing lines and spots of dark gray, or mauve. The whole effect is soft gray. The lower surfaces are white.

$\begin{array}{cc}\text { Dimensions: - Total length } & 60 \mathrm{~mm} \text {. (tail imperfect) } \\ \text { Tip of snout to vent } & 30 \mathrm{~mm} \text {. } \\ \text { Tip of snout to ear } & 8 \mathrm{~mm} . \\ \text { Width of head } & 6 \mathrm{~mm} . \\ \text { Fore leg } & 13.5 \mathrm{~mm} . \\ \text { Hind leg } & 19 \mathrm{~mm} .\end{array}$

Anolis loysiana is by no means a common lizard or at least it is by no means easy to find. It is a curious looking, rather sluggish, flat little creature, relying upon its wonderful protective coloration to escape notice. It is found usually upon the rough grayish bark of trees and on bark like that of the Ceiba (Bombyx) it is literally invisible unless it moves. The example described from Los Negros in the Sierra Maestra was taken upon gray limestone, the rocky bank cut down by a rapid torrent (Barbour); two examples from Bayate, Oriente (Ramsden), and one from San Diego de los Baños (Palmer and Riley) are important in that they show that the spine-like scales are not confined to the males as stated by Boulenger (Cat. lizards Brit. mus., 1885, 2, p. 42). He considered Anotis argillaceus Cope a synonym of this species and probably concluded from Cope's description being in some respects similar, but mentioning no spines, it represented the female of A. loysiana. As a matter of fact it is not very closely related; loysiana is found, as stated by Gundlach, all over Cuba wherever forested areas offer a suitable habitat.

\section{Anolis Argillaceus Cope.}

Plate 7, fig. 6.

Lagartija.

Diagnosis: - A small, very thickset, short limbed Anolis, with excessively small granular, scales upon the body, with rather ill-defined verticils upon the cylindrical tail. Mottled brown in colour with usually a light longitudinal streak along the body and a very dark brown band across the head between the eyes.

Description:-Adult or M. C. Z. 10,707. Cuba: Oriente; Bayate, 1913. C. T. Ramsden.

Top of head with very faintly indicated frontal ridges, which inclose a 
more or less circular and very slightly depressed area paved with three flat polygonal scales; ridges not indicated on the snout; head-scales all flat; about four scales in a row between the nostrils; supraocular semicircles (as in loysiana) composed of large scales broadly in contact their entire distance along the median line; occipital large, about twice as large as ear opening, separated from the supraocular semicircles by two rows of pavement-like polygonal scales; supraocular disc consisting of an anterior large scale, two smaller scales and a fourth very small scale, all the four so fitting one another as to compose an oval pattern (in other specimens the oval dise may be composed of only two scales); dise separated from semicircle by one or two rows of scales; canthus rostralis consisting of about four slightly elongate scales, canthus prolonged backward to a point above centre of eye. Loreal rows, two or three; seven smooth supralabials, suture between sixth and seventh under the centre of the eye; temporals mostly flat but smallest and slightly tubercular in the centre of the temporal area. Supratemporal line indicated by a row of flat juxtaposed scales; no enlarged dorsals, back and sides covered with minute brown or oblong flat or slightly tubercular scales, homogenous in character; ventrals larger, slightly imbricate and perfectly smooth; scales of the anterior aspect of fore and hind limb enlarged, smooth and imbricating; limbs short, digits shorter than usual in the genus; the hind limb being adpressed forward reaches about the ear opening; digital expansions moderately developed, about twenty lamellae under phalanges II and III of fourth toe; tail rather long and slender, much more than twice as long as head and body, slightly compressed at the base, covered with keeled and imbricating scales with verticils at intervals of about six or seven scales; two well-developed postanal plates.

Colour (alcoholic specimen):- Body grayish of rather a light tone, mottled and spotted with darker; dewlap pinkish shading to orange at the margin; a dark postoccipital spot and a dark band between the eyes.

$\begin{aligned} \text { Dimensions:- } & \text { Total length } \\ & \text { Tip of snout to vent } \\ & \text { Vent to tip of tail } \\ & \text { Tip of snout to ear } \\ & \text { Width of head } \\ & \text { Fore leg } \\ & \text { Hind leg }\end{aligned}$

$121 \mathrm{~mm}$.

$36 \mathrm{~mm}$.

$85 \mathrm{~mm}$.

$12.5 \mathrm{~mm}$.

$8 \mathrm{~mm}$.

$14 \mathrm{~mm}$.

$25 \mathrm{~mm}$.

Generally speaking the colouration of this species is composed of longitudinal light and dark stripes along the body and one light lateral band at least 
is almost always present. It was first taken by Charles Wright at the Cafetal Monte Verde in the Sierra de Yateras, and rediscovered there; it has also been collected at Monte Libano, at Bayate near Guantanamo and at La Maya (Ramsden), and seems to be entirely confined to eastern Oriente. Curiously enough it is found most frequently in the coffee groves of the damp mountain forests. A few specimens, however, have been secured in lowlands about three miles S. E. of Guantanamo City and upon Guasima trees at the San Carlos sugar plantation. It is a slow moving, rather chunky, thickset Anolis, not depressed like loysiana and very different in appearance from any other in Cuba. The character of the head-scales recalls the condition in loysiana, but the tail is entirely different, much longer and differently formed, there are no spine-like projecting scales as in that species, and the dewlap is very much larger.

\section{Anolis spectrunt Peters.}

Plate 7, fig. 5.

Lagartija.

Diagnosis: - An excessively long and slender Anolis, head nearly three times as long as broad; grayish or greenish with a conspicuous white spot on the elbows.

Description: - Head nearly three times as long as broad, longer than the tibia; forehead concave; upper head-scales smooth; scales of the supraorbital semicircles large, separated by one series of scales; three or four enlarged, keeled supraocular scales, in contact with the supraorbitals; occipital nearly as large as the ear opening, separated from the supraorbitals by one or two series of scales; canthus rostralis feebly marked; loreal rows, four; eight supralabials; ear opening moderately large, roundish; gular appendage small; gular scales keeled; body compressed; no nuchal nor dorsal fold; six or eight longitudinal scries of large, hexagonal, keeled dorsal scales, which are broader than long, and at least twice as large, as the ventrals; lateral scales very small, granular; ventral scales keeled; the adpressed hind limb reaches between the ear and the eye; tail round or slightly compressed, covered with large strongly keeled scales, the keels forming continuous lines; its length more than twice that of head and body (after Boulenger).

Colour (alcoholic specimen):- Yellowish gray or metallic green above, the sides of the body brown; a sharply defined white spot at the elbow. 


Dimensions: - Total length
Tip of snout to vent
Vent to tip of tail
Width of head
Fore leg
Hind leg

$150 \mathrm{~mm}$.

$40 \mathrm{~mm}$.

$110 \mathrm{~mm}$.

$4.5 \mathrm{~mm}$.

$13 \mathrm{~mm}$.

$28 \mathrm{~mm}$.

No one except Gundlach himself has ever taken this species. We have searched for it in vain. Gundlach remarks that he found it only in "monte," as a certain sort of lowland forest is called in Cuba, in the jurisdictions of Matanzas and Cárdenas. He adds that the species is rare. We believe the only specimen preserved in America is the imperfect one, in the Museo Gundlach of the Institute de Segunda Enseñanza in Havana. It is a strange looking wraith of a lizard, so slender that it resembles a fine twig as closely as the wellknown walking sticks (phasmids) do. In 1918 we again examined the type as carefully, as possible, at a distance of perhaps sixteen or eighteen inches, for the case is kept permanently sealed at Gundlach's most earnest request. We conclude that the species may probably be a synonym of Anolis alutaceus, but had best be kept separate until the types can be reëxamined.

\section{Anolis cyanopleurus Cope.}

Plate 4, fig. 1; Plate 6, fig. 6; Plate 8, fig. 1-3.

Diagnosis:- A small slender greenish Anolis, having long low almost parallel frontal ridges, a few rows of enlarged scales in a light streak along the middle of the back, and a very long tail without distinct verticils.

Description:-Adult? ㅇ Brit. Mus. N. H. 65.6.12.18. Cuba: Juan Gundlach.

Top of head with two nearly parallel and closely approximated frontal ridges, which are not greatly developed and border a shallow frontal trough; head-scales very feebly to rather distinctly keeled; about eight scales in a row between the nostrils; supraoculars semicircles separated by one or two scales; occipital large but somewhat smaller than ear opening, separated from the supraocular semicircles by but two rows of seales; supraocular disc consisting of three or four greatly enlarged irregularly shaped polygonal scales and several smaller ones, separated from the semicircles by a row of still smaller scales; canthus rostralis consisting of about five or six narrow elongate scales, continued posteriorly, these form a superciliary ridge of elongate scales which 
separate the supraocular granules from those surrounding the eye; loreal rows, five; subocular semicireles of strongly kecled scales broadly in contact with the supralabials; six or seven smooth supralabials, suture between fourth and fifth under the centre of the eye; temporals very finely granular in the centre with a very feebly indicated supratemporal line; about eight dorsal rows of scales distinctly enlarged, of these the median four rows with a moderately well-developed keel, two median rows slightly imbricate, others juxtaposed; rest of back and sides covered with minute granules; ventral scales as large as or a little larger than the largest middorsals, slightly imbricate and feebly but evidently keeled; scales of forelimbs imbricate either uni- or pluricarinate, on hind limbs all imbricate scales with two or three keels; scales on upper surface of digits pluricarinate; digits of hind limbs very long and slender, the expansion very feebly developed; about twenty-seven lamellae under phalanges II and III of fourth toe; tail very long, much more than twice as long as head and body, slightly compressed at the base, covered with subequal keeled scales, with scarcely any indication whatever of verticils, with but the very faintest indication of a serrated edge above; postanal plates very slightly developed ( 9 ?).

Colour (alcoholic specimen):- Body greenish, a lighter and bronzy dorsal stripe not very sharply defined; limbs brown, tail lighter in tone than body.

$\begin{array}{lr}\text { Dimensions: - Total length } & 127 \mathrm{~mm} . \\ \text { Tip of snout to vent } & 38 \mathrm{~mm} \text {. } \\ \text { Vent to tip of tail } & 89 \mathrm{~mm} . \\ \text { Tip of snout to ear } & 9 \mathrm{~mm} \text {. } \\ \text { Width of head } & 5.5 \mathrm{~mm} \text {. } \\ \text { Fore leg } & 13 \mathrm{~mm} . \\ \text { Hind leg } & 30 \mathrm{~mm} \text {. }\end{array}$

So far on none of our excursions have we ever been able to find this fine little Anolis, hence we know of it only from the literature. Cope described it (Proc. Acad. nat. sci. Phila., 1861, p. 211) from the famous Cafetal "Monte Verde" in the Sierra de Yateras of Guantanamo. The types were secured by Charles Wright and were catalogued 5,737 in the Smithsonian collection; they have apparently been lost. Gundlach found specimens, some of which he sent to Peters and one of these was figured by Bocourt (Miss. sci. Mex., pl. 16, fig. 29). It is interesting to compare a facsimile of his figure with one of Mr. Fischer's excellent drawings, the latter made from one of three specimens which Peters sent in exchange to the British Museum. For the opportunity of ex- 
amining this example we have to thank Dr. G. A. Boulenger, and the Trustees of the British Museum.

It will be noted that Bocourt's figure shows the head-scales overlapping, which is not the observed condition, although in general the arrangement of the scales seems fairly accurately drawn. That he has the head too broad may be in part due to the possibility that he had a male before him. The position of the occipital, however, is such as to make it quite possible that he had some other species.

The figured specimen, as will be seen by comparing the description given herewith, agrees sufficiently well with Cope's original notice to make it reasonably sure that Peters was correct in assigning this one of Gundlach's specimens to Anolis cyanopleurus.

Unfortunately, Gundlach in his Erpetologia Cubana (1880, p. 48) has not much to say of the habits or distribution. He only states

"He observado esta especie en bosques de la vecindad del pueblo de Cimarrones en la jurisdiccion de Cárdenas y en la Sierra Maestra del departmento oriental. Es una especie muy rara."

Concerning the colour in life, however, Gundlach gives us an excellent account. He describes a living example from the Sierra Maestra as follows:--

"Ojo muy oscuro, casi negro, con un circulo azul al rededor de la pupila. El color general es olivado-pardo, claro; encima de la cabeza, del dorso y la raiz del rabo hay manchitas irregulares confluentes negruzcas. El rabo $\left[{ }^{1}\right]$ en su mitad final es negruzco tanto por encima como por debajo. Las partes inferiores son más pajizas, y el borde de la mandíbula superior, debajo del ojo y la garganta son blancuzcos; hay ítomos negros en las extremidades y una mancha negruzca sobre el codo y la choquezuela, además manchitas en el resto de las extremidades; $\frac{2}{3}$ del rabo [1] hasta la punta blancuzcos con átomos y algunas manchitas negruzcas.

Su forma es delgada, el rabo tiene 3 veces el largo del cuerpo. El tamaño total llega á $5_{2}^{1}$ pulgadas.

Descripcion de un ejemplar de Cimarrones.

Cabeza ceniciento-verde; nuca lo mismo, pero más pálida. A lo largo del dorso, hasta donde hay escamas mayores, está una faja pajiza; flancos ceniciento-verdes ó azulosos, los márgenes hácia arriba más oscuros. A lo largo de la mandíbula superior se extiende una línea pálida ó pajiza, pero con los bordes aún más pálidos.

Otro ejemplar tenía sobre la faja dorsal algunas manchas oscuras; sobre el intermedio de las extremidades posteriores se ve una mancha en forma de $V$ (con el ápice dirigido hácia atras). Los flancos están tambien manchado de oscuro, y la faja blancuzca de la mandíbula superior se continúa á lo largo del lado del cuerpo con una faja pálida, á intervalos (principalmente en el sobaco) bordada de negro."

This it will be observed is a colouration not so very different from that of the example in the British Museum which we have had for study. 
Just as this paper was ready for the press the junior author succeeded in finding this beautiful little species at La Aleachofa in the Sierra de Yateras, near Guantanamo; the very region whence the type came and doubtless near one of Gundlach's localities, for he found it near Cimarrones and "in the eastern part of the island."

The species is very lovely, the style of colouration very fine. 'The sharply defined dorsal zone is russet with or without narrow cross-markings; the sides grass-green, the belly clear white as also the lip margins. The dewlap seems inconspicuous and ashen gray.

The long fine tail, the slender form and many details of squamation recall sharply A. semilineatus of Haiti and San Domingo.

\section{Anolis alutaceus Cope.}

Plate 9, fig. 1.

\section{Lagratija.}

Diagnosis: - A beautiful little brown woodland Anolis, almost as slender as $A$. spectrum (quod vide) but with smooth ventral scales.

Description:- Adult न न M. C. Z. 8,465. Cuba: Jiguaní, Los Negros (High Sierra Maestra), March, 1913. Thomas Barbour.

Top of head with two low almost parallel ridges, converging anteriorly, enclosing a very long, trench-like depression, paved with slightly rugose scales; head-scales generally multistriate, sometimes simply rugose; about eight scales in a row between the nostrils; supraocular semicircles not strongly marked, separated by one row of small scales; occipital irregularly oval, slightly larger than ear opening, separated from the semicircles by several rows of scales; supraocular dises large, irregular, composed of about six or seven enlarged, many keeled scales, in contact with the semicircles or separated by one row of very small seales; canthus rostralis composed of about five scales, not prominent, supraciliary ridge very indistinct; loreal rows, five; subocular semicircles distinct, composed of several large keeled scales, widely in contact with supralabials; about nine smooth supralabials, suture between seventh and eighth being about under centre of eye; temporals, especially the central scales, very small; no trace of supratemporal ridge; gular appendage small and elongate; about eight rows of enlarged weakly keeled middorsals, other dorsals and laterals minute; ventrals smooth and round or oblong, parchment-like, not in- 
bricating; scales of anterior aspects of fore and hind limbs strongly enlarged, keeled and imbricate; body slender cylindrical or slightly compressed; no nuchal nor dorsal fold; limbs very slender, the adpressed hind limb reaching to between the orbit and nostril; about seventeen lamellae under phalanges II and III of the fourth toe; digital dilation very slight; tail round, very slender, covered with rather large keeled and imbricate scales, no trace of verticils; no enlarged postanal scales.

Colour (in life):- Varying shades of brown from light golden cinnamon to deep umber, often a light dorsal zone, this may or may not have within it a dark series of dorsal spots; head with varying light and dark cross-bands and longitudinal stripes; lower parts and dewlap (which is scarcely extensible) pale brown.

$\begin{aligned} \text { Dimensions: - } & \text { Total length } \\ & \text { Tip of snout to vent } \\ & \text { Vent to tip of tail } \\ & \text { Width of head } \\ & \text { Fore limb } \\ & \text { Hind limb }\end{aligned}$

$120 \mathrm{~mm}$.

$35.5 \mathrm{~mm}$.

$84.5 \mathrm{~mm}$.

$4.5 \mathrm{~mm}$.

$13 \mathrm{~mm}$.

$28 \mathrm{~mm}$.

Anolis alutaceus was another of the discoveries made by Charles Wright, at the old Cafetal "Monte Verde" in the Sierra de Yateras near Guantanamo. One of Wright's original specimens, a type, is now before us (M. C. Z. 10,932), secured through the kind offices of Dr. Leonhard Stejneger by exchange from the U. S. N. M. In the M. C. Z. there are other specimens from Madruga, Cienfuegos, Mayajigua, Sierra de Cubitas, Monte Libano as well as from the forests of the Sierra Maestra (Cafetal "El Alto" above Los Negros), where the species was fairly abundant (de la Torre and Barbour). In the collection of the junior author there are many others from the mountain forests about Guantanamo. This slender little lizard is by no means easy to find, unless one happens to see it move. It is usually entirely confined to forested areas, apparently more abundant in highland than in lowland forest but found in both. One observed crossing the hot, white and dusty "calzada" between Madruga and Aguacate at high noon crept leisurely across the burning limestone road and it was most surprising that so tiny a creature did not parch and blow away. We have observed it feeding upon the ants which swarm along the twigs of so many Cuban forest trees. In common with, we believe, all members of the genus, this species lays a single oblong egg under'a bit of half decayed bark. One such egg was found near Baire with an almost ripe embryo (Barbour). 


\section{ANolis homolechis Cope.}

Plate 14, fig. 8.

\section{Lagartija.}

Diagnosis:-A dark coloured, woodland Anolis, one of the few Cuban species having, in the adults, a conspicuous fin-like crest upon the tail and the only species having a pure, ivory-white dewlap.

Description:-Adult ơ M. C. Z. 8,575. Cuba: near Matanzas. Carlos de la Torre.

Top of head with two almost parallel ridges of keeled scales, extending but half way to tip of snout and separated by first one then two rows of keeled scales; head-scales all sharply keeled; about six scales in a row between the nostrils; supraocular semicircles are formed by backward extensions of frontal ridges, and are separated by one row of scales; occipital oval, much smaller than ear opening, separated from the semicircles by two or three rows of scales; supraocular dise much differentiated, composed of a number of variously enlarged, keeled scales, separated from the semicircles by one row of very small scales; canthus rostralis sharply defined, composed of four or five keeled elongate scales; extending backward it forms a superciliary ridge which reaches to over the posterior portion of the eye; loreal rows, four or five; subocular semicircles distinct, sharply depressing the supralabials; about ten smooth supralabials, the suture between the seventh and eighth under the centre of the eye; temporals fine and granular, a faintly indicated supratemporal line; dorsal and lateral scales minute and granular, two middorsal rows of granules slightly enlarged; ventrals large, smooth, cycloid, strongly imbricating; scales of anterior aspects of fore and hind limbs enlarged, imbricating and strongly keeled; body stout, no nuchal nor dorsal fold, limbs well developed, the adpressed hind limb reaches the anterior border of the orbit; digits much dilated, about seventeen lamellae under phalanges II and III of the fourth toe; tail not greatly elongated, very strongly compressed, surmounted by a highly developed fin-like crest; the whole caudal squamation regularly divided by verticils, the seales on the tail between the limiting rows small, increasing in size on the fin progressively upward, the fin surmounted by fine saw-like teeth three between each verticil, the fourth enlarged and forming the upper scale of each limiting row; postanal scales very slightly if at all enlarged. 
Colour (in life):- Dark rich brown almost black, when at rest; when disturbed may become light brown with darker dorsal rhombs; lower surfaces paler; dewlap pure white. (Specimens from various localities).

$\begin{array}{lr}\text { Dimensions: - Total length } & 147 \mathrm{~mm} . \\ \text { Tip of snout to vent } & 57 \mathrm{~mm} . \\ \text { Vent to tip of tail } & 90 \mathrm{~mm} . \\ \text { Width of head } & 10.5 \mathrm{~mm} \text {. } \\ \text { Fore leg } & 13.5 \mathrm{~mm} \text {. } \\ \text { Hind leg } & 45 \mathrm{~mm} .\end{array}$

This lizard is the most common and widely distributed of all the Cuban species which are strictly confined to a woodland habitat. We have found it in all of the provinces and in greater or less abundance in all the woodland areas examined. It is evidently most at home on the tree-trunks of some sunlit jungle glade where insects abound. In such spots the males may often be seen bobbing their heads up and down as they flash the pure white of their widely expanding dewlap. When shot or otherwise wounded their tail has a peculiar way of convulsively rolling up, which almost suggests a prehensile usage, such as we have never observed. Cope founded this species upon a specimen in the British Museum which had only "West Indies" as data. Until the type can be examined there will remain some doubt as to the real status of homolechis, for Cope's description leaves much to be desired and even Boulenger's was published before anyone realized how many were the species of Anolis and how similar many of them are to each other.

38. Anolis rubribarbus, sp. nov.

Plate 9, fig. 2, 3.

Lagartija.

Diagnosis:- A rather stockily built Anolis, having in the male a high fin-like crest upon the tail, smooth ventral scales and a dewlap light red with a yellow margin and crossed obliquely by three bars of a much deeper red.

Description:- Trpe. Adult ơ M. C. Z. 11,941. Cuba: Oriente; El Puerto de Cananova, near Sagua de Tánamo, May, 1916. V. J. Rodriguez y Verrier.

Top of head with two rather short and but slightly bowed ridges, enclosing a distinctly depressed area; ridges at their greatest width from each other 
separated by about five rows of rugose or tricarinate scales; head-scales generally keeled or rugose; about seven seales in a row between the nostrils; supraocular semicircles separated by two or three rows of rugose or keeled scales; occipital oval, about one half the size of ear opening; separated from the semicircles by about four rows of scales; supraocular discs large, not very sharply defined, composed of a large number of not very greatly enlarged, keeled scales; canthus rostralis prominent, composed of about seven keeled scales, extending almost to nostril, extending backward it forms a distinct superciliary ridge which extends posteriorly to the centre of the eye; loreal rows, seven; subocular semicircles composed of large keeled scales, broadly in contact with supralabials; eight smooth supralabials, the suture between the sixth and seventh being about under the centre of the eye; temporals granular, the central scales of the temporal area smallest, a faintly indicated supratemporal line; scales of back and sides small and granular, no enlarged middorsals; ventrals large, cycloid, imbricating, smooth; scales of anterior aspect of both fore and hind limbs enlarged, imbricating and strongly keeled; body short and strongly compressed; a well-defined nuchal and dorsal fold; the adpressed hind limb reaches almost to the nostril; about seventeen lamellae under phalanges II and III of the fourth toe; digital dilations well developed; tail very strongly compressed, with a high "fin"; each section of the fin composed of about nine rows of scales which are rather uniform in size (not increasing in size in a dorsal direction as in homolechis); the scales of the limiting rows are not very greatly enlarged upon either tail or "fin"; postanal scales not conspicuously enlarged.

Colour (freshly killed specimen):- Grayish brown, darker vertical bands upon body and tail; throat in both males and females streaked longitudinally; scattered light dots upon lips and sides; dewlap very large, of a rather brilliant light brick-red, edged with light yellow, almost white upon the thickened margin and crossed by three deep carmine oblique bands upon the light brick-red ground.

$\begin{array}{lc}\text { Dimensions: - Total length (tail slightly mutilated) } & 130 \mathrm{~mm} . \\ \text { Vent to tip of tail } & 55 \mathrm{~mm} . \\ \text { Width of head } & 7.5+\mathrm{mm} . \\ \text { Fore leg } & 25 \mathrm{~mm} . \\ \text { Hind leg } & 48 \mathrm{~mm} .\end{array}$

We little expected so remarkable a novelty as the one here described, when in the spring of 1916 Señor Rodriguez started on a collecting trip to the northern coastal region of eastern Oriente. The greatly developed fin with its 
singularly homogeneous squamation as well as the very peculiar colouration of the dervlap serve at once to distinguish it from any other species. Beside securing a small series near Cananova, a single adult male was found out on the Farallones of Cabo Maisí itself. We know nothing of its wider distribution nor of its habits.

39. Anolis QUadriocellifer, sp. nov.

Plate 10, fig. 1.

Lagartija.

Diagnosis: - A rather thickset Anolis, bearing a well-developed fin upon the tail and having upon each side a large very dark brown blotch upon a light brown ground, the blotch completely surrounded by more or less confluent small pure white dots.

Description:- Trpe. Adult જ M. C. Z. 11,867. Cuba: Cabo San Antonio, Ensenada de Cajón, 1914. Carlos de la Torre.

Top of head with two very short parallel ridges; separated by two or three rows of keeled scales; head-scales all sharply keeled; about eight seales in a row between the nostrils; supraocular semicircles separated by a partly single, partly double row of keeled scales; occipital irregular almost round, much smaller than ear opening, separated from the semicircles by two or three small scales; canthus rostralis distinct of three or four elongate scales, continued backward as a supereiliary erest to over centre of eye; loreal rows, four; subocular semicircles short, composed of a few long, keeled scales, broadly in contact with supralabials; seven smooth supralabials, sixth under eye; temporals granular, the central group very minute, a series of slightly enlarged scale forming a faintly defined supratemporal line; scales of back and sides granular, the two middorsal rows slightly enlarged; ventrals large, round, smooth, and strongly imbricate; scales of anterior aspect of fore and hind limb enlarged, strongly keeled and imbricate; body short, compressed; a distinct nuchal continuous with a distinct dorsal fold; limbs rather short, the adpressed hind limb reaching just beyond the ear opening; about eighteen lamellae under phalanges II and III of fourth toe; tail very strongly compressed, surmounted by a well-developed fin, the whole tail and fin segmented into verticils, each limiting row separated by seven scales on side of tail (where the limiting rows are faintly defined) and separated on the fin by five rows where the limiting 
rows are well enlarged and perfectly evident; on the upper edge of the fin three saw-tooth scales separate the uppermost scale of two limiting rows; postanal scales slightly enlarged.

Colour (in alcohol): - Brown, dark above, light beneath; on each side of the thoracie region two very dark blotehes surrounded by more or less confluent small white spots. The dewlap appears to have been pink.

This interesting novelty was discovered by Dr. Carlos de la Torre of the University of Havana during the cruise of the Tomas Barrera while collecting molluses at Cabo San Antonio, the western extremity of Cuba, as the guest of John B. Henderson, Esq., of Washington. Three specimens were secured, in a small wooded area near the Ensenada de Cajon on the north coast of the Cape. All three specimens are in exact agreement with regard to the peculiar colouration. From this fact it is very probable that as with certain other colour-characters in species of Anolis these dark spots surrounded with white dots represent a permanent colour-pattern, while the ground colour of the rest of the body may vary a great deal.

40. ANolis allogus, sp. nov.

Plate 10, fig. 2.

Lagartija.

Diagnosis: - A heavy thickset Anolis, confined to woodlands, having a strongly compressed tail with a well-developed "fin"; smooth ventral scales and dewlap carmine in the centre surrounded by a broad marginal zone of brilliant yellow.

Description:- Trpe. Adult ơ M. C. Z. 8,544. Cuba: Oriente; Bueycito near Bayamo. (Sierra Maestra), 1913, Cuban Exped. Carlos de la Torre, Thomas Barbour, and V. J. Rodriguez.

Top of head with two short, rather indistinct, widely bowed ridges, where farthest apart separated by three or four series of faintly keeled or rugose scales; head-scales weakly keeled or rugose; about nine scales in a row between the nostrils; supraocular semicircles separated by two rows of keeled scales; occipital roughly rotund, in a distinctly depressed area, less than one half the size of the ear opening; separated from the semicircles by four or five rows of slightly enlarged rugose scales; supraocular dises irregular, composed of twelve to fourteen enlarged weakly keeled scales, separated from the semicircles by a single row of granules; canthus rostralis distinet, of five or six scales, prolonged 
posteriorly it forms a distinct superciliary ridge to over the hinder third of the eye; loreal rows, five; subocular semicircles not very distinct, composed of enlarged but rather weakly keeled scales, in contact with supralabials; eight supralabials, the posterior two weakly keeled, the sixth under the centre of the eye; temporals granular, those of the central temporal area smallest, a faintly indicated supratemporal line; scales of back and sides minute and granular, about four middorsal rows slightly enlarged, weakly keeled and slightly imbricating; ventrals larger but not very large, smooth, cycloid, and imbricating; scales of anterior aspects of fore and hind limbs enlarged, keeled and imbricating; body short and compressed, a well-developed nuchal but scarcely a trace of a dorsal fold; limbs rather long, the adpressed hind limb reaches to between eye and nostril; about fifteen lamellae under phalanges II and III of fourth toe; digital dilatations well developed; tail rather long, strongly compressed; a fold along the top of the tail has a slight tendency toward a "fin" (in old males the "fin" may be well developed but it does not appear to be invariably equally high); tail with evident verticils, limiting rows separated by about eight scales on upper part of side of tail and by only about four or five on the lower part of the side; postanal scales not distinctly enlarged.

Colour (in life):-- Varying shades of brown or blackish with or without dorsal rhomboid markings, the rhombs often becoming confluent and forming a light middorsal zone; throat with a mesh of gray lines, lower'surfaces light brown or ochraceous; dewlap enormously developed (as in A. bremeri) with a rich carmine spot upon a brilliant yellow ground.

$\begin{array}{cr}\text { Dimensions: - Total length } & 166 \mathrm{~mm} . \\ \text { Tip of snout to vent } & 62 \mathrm{~mm} . \\ \text { Vent to tip of tail } & 104 \mathrm{~mm} . \\ \text { Width of head } & 10.5 \mathrm{~mm} . \\ \text { Fore leg } & 29 \mathrm{~mm} . \\ \text { Hind leg } & 51.5 \mathrm{~mm} .\end{array}$

This species was discussed at some length as $A$. angustirostris Hallowell (Barbour, Mem. M. C. Z., 1914, 44, p. 292). The discovery later of Hallowell's type made it clear that the name should be applied to a totally different species. This lizard, which is a common woodland species throughout most of the Province of Oriente, has probably been seen and caught by most collectors in Cuba but mistaken variously for $A$. sagrei, $A$. homolechis, and perhaps other species. It is usually dark brown or black when at rest and may ordinarily be found resting 
head downward upon the trunks of large forest trees. It has, like homolechis, the curious habit of convulsively curling and uncurling the tail when it is wounded or noosed; and when it is at rest the tail is almost always kept more or less tightly curled up. The enormously developed and brilliant dewlap often suddenly expanded with a quick nodding motion of the head make a bright flash of colour in the sombre forests which allogus frequents. The large series now in the M. C. 'L. are from Los Negros, Baire, Jiguani, San Luis, Pozo Prieto, and Monte Libano (de la Torre, Barbour, and Rodriguez); the collection of the junior author contains specimens from many stations about Guantanamo, and Sagua de Trinamo, while Mr. J. L. Peters found what we believe to be this species in the neighbourhood of Mayari and Nipe Bay while collecting there for the M. C. Z. in 1915. Thus its distribution is general where there are forests in the Province of Oriente.

41. Anours mestrei Barbour \& Ramsden.

Plate 10, fig. 3.

Lagartija.

Diagnosis: - A rather small but not a slender Anolis, in general appearance like the common $A$. sagrei, but it may be recognized at once, since it has a white dewlap with a large red-brown spot on its base.

Description:- Trpe. Adult M. C. Z. 11,285. Cuba: Pinar del Rio; Valley of Luis Lazo, March, 1915. Thomas Barbour.

Head with two slightly diverging ridges on the frontal region; forehead concave; all the head-scales rather feebly keeled; seen from in front, rostral about the same height as the mentals; six elongate scales between the nostrils; a single series of scales separating the supraocular semicircles; occipital slightly smaller than ear opening, separated from the supraocular semicircles by about four rows of scales, which are very much larger than the dorsal granules and slightly larger than the scales which bound the occipital posteriorly; supraorbital dise composed of about six large and a few additional smaller but somewhat enlarged scales; these are all very feebly keeled and arranged in gradation, the largest scales nearest the scales of the semicircles, which they equal in size; there are about three series of enlarged scutes in the discs; dise separated from semicircles by one row of granules; three or four scales between the super- 
ciliaries and the supraorbital semicircles bounding the area of the supraorbital granules anteriorly; canthus rostralis sharp, consisting of five or six elongate shields which are continuous with the superciliaries; loreal rows five or six; subocular semicircles in contact with supralabials; supralabials six, the suture between the fifth and sixth under the centre of the eye; temporals excessively minute, granular, no enlarged series forming a supratemporal line; dorsal and lateral scales minute, granular, none on the middorsal line enlarged; ventral scales medium in size, flat, imbricate, without trace of keel; scales of throat and chest also smooth; fore limbs above with small, imbricate, very feebly keeled scales, smaller than the ventrals; femur and tibia with similar but slightly larger and smooth or very feebly keeled scales; fingers and toes above not distinctly carinate; digital expansion narrow, above fifteen lamellae under phalanges II and III of fourth toe; tail (broken in type); long in U. S. N. M. 26,731 , compressed, without a "fin," divided into irregular segments of about five keeled scales each, the limiting row of each segment slightly enlarged); in type, dewlap rather large, with smooth scales, anterior edge slightly thickened; postanal scales not enlarged.

Colour (in life): - Mottled gray-brown, of more or less a "salt and pepper" appearance. Dewlap white, with a large rich red-brown spot at its base, surrounded by the white; the scales of the brown area white like the rest, the skin only coloured. - Belly whitish but throat with longitudinal dark lines.

There is marked variation in the degree of carination of the head-shields; U. S. N. M. 26,931 has them almost smooth, yet we do not believe that this specimen represents a different species. The species seems to be one which is found almost wholly along the edges of woods on the trunks of trees and in shrubbery. It was observed frequently in March 1915 in the Valley of Luis Lazo (Barbour) though a few only were secured, a circumstance undoubtedly due to a necessarily hasty ending of a collecting trip owing to the illness of Mr. W. S. Brooks.

We recognized the species at once in life as one completely unknown to us and one which we have not seen elsewhere during many journeys throughout Cuba. We do not believe that this species is rare but it is probably one which is usually mistaken for $A$. sagrei. It should be looked for among any of the limestone ranges of Pinar del Rio Province. 


\section{Anolis porcatus Gray.}

Plate 14, fig. 9.

\section{Lagartija verde.}

Diagnosis: - $\mathrm{A}$ depressed brilliant green or brown Anolis, with an elongate, flattened head with strong rugose scales, the digits greatly dilated, the tail round and the dewlap light carmine, the gular scales being white.

Description:-Adult o M. C. \%. 10,881. Cuba: Pinar del Rio; Guane, March, 1915. Thomas Barbour.

Top of head with strong heavy parallel ridges upon the elongate snout; all the head-scales heavily keeled or strongly rugose; six scales in a row between the nostrils; supraocular semicircles elevated and very rugose, separated by a row of rugose scales; occipital and ear opening small, of about the same size; supraocular dises not strongly defined, composed of about twelve rugose scales; separated from the semicircles by a row of keeled scales; canthus rostralis extremely prominent, long, composed of five or six large scales, extending backward a single long scale forms a short superciliary ridge; loreal rows, three; subocular semicircles long, composed of keeled scales in contact with supraoculars; nine or ten slightly rugose supralabials, the seventh under the eye; temporals rather large and flat, all about the same size, no trace whatsoever of a supratemporal line; scales of back and sides, equal, often faintly keeled and with a slight tendency to imbricate; ventrals not much larger than laterals, faintly keeled and slightly imbricate; scales of anterior aspect of fore and hind limbs not enlarged; body elongate, depressed; a very inconspicuous nuchal and dorsal fold; limbs medium long, with large digital dilations; the adpressed hind limb reaches to about the ear opening; about thirty-two lamellae under phalanges II and III of the fourth toe; tail long, round or slightly depressed at the base, with verticils weakly indicated at four scale intervals, scales of limiting row not greatly enlarged; postanals not enlarged.

Colour (in life):- Body and tail usually grass-green, the head (in adult males) often sky-blue; the colour may change to green with a rufous dorsal stripe or to brown variously streaked and vermiculated with green or vice versa. The throat and lower surfaces are often sparingly streaked and dotted with dark brown. The belly is whitish; the dewlap skin is light carmine, the scales being white, the carmine in adult males is extended to form a rather large pink spot upon the throat. 


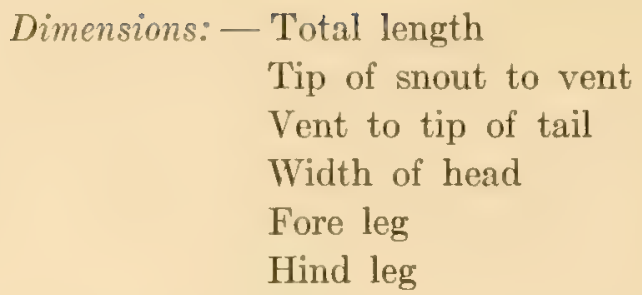

$202 \mathrm{~mm}$.

$66 \mathrm{~mm}$.

$136 \mathrm{~mm}$.

$11 \mathrm{~mm}$.

$24 \mathrm{~mm}$.

$41 \mathrm{~mm}$.

This large and beautiful Anolis represents in Cuba the abundant and familiar Anolis carolinensis Voigt of the southern United States. The two species have often been confused, even by such an authority as Boulenger. They are very distinet. Anolis brunneus Cope of the Bahamas is, in some respects, rather intermediate between the Cuban and Floridan forms.

In Cuba Anolis porcatus is widely distributed and it is one of the best known and most easily recognized reptiles of the island. It has adapted itself specially to life in gardens and it often comes to the windows and verandas of country houses in search of its insect prey. They are particularly wont to sun themselves upon the many agaves or magueyes so often planted in Cuban gardens. In the Botanical Gardens in Havana and in many of the well-planted plazas of the larger provincial towns Anolis porcatus is a beautiful and attractive denizen. In the unsettled districts it frequents the sunny margin of the forests, but is excessively rare except in cultivated lands. We have collected and examined specimens in all of the six provinces. It is especially abundant about the city of Camaguey.

\section{Norops ophiolepis (Cope).}

Plate 14, fig. 10.

\section{Lagartija de la Yerba.}

Diagnosis:- A small terrestial Anolis-like lizard which may be distinguished from any of the members of that genus by the absence of digital dilatations. The back, sides, and belly are all covered with sharply keeled, imbricating scales.

Description:-Adult M. C. Z. 7,923. Cuba: Soledad near Cienfuegos, February, 1910. Thomas Barbour.

Top of head with very faintly indicated ridges which are almost parallel (in some specimens they are not evident at all); supraocular semicircles indistinct; separated from each other by two or three large, strongly keeled scales; head-scales all heavily keeled; occipital oblong, small, about two thirds the size 
of ear opening; separated from the semicircles by three or four scales; supraocular dises large and broadly in contact with the semicircles; canthus rostralis very prominent and composed of but two greatly elongate scales; three or four elongate scales which overlap broadly form a ridge over three fourths of the eye; loreal rows very irregular, about four; lower eyelid very broad covered with minute granules; subocular semicircle fecbly developed, its seales not greatly enlarged; six supralabials, four long and two short, the fourth under the centre of the eye, temporal scales scarcely differentiated, feebly keeled and slightly imbricate; no indication of a supratemporal line; scales of back composed of about twenty-one enlarged, keeled, and imbricate scales, those of sides decreasing in size vertically and sharply differentiated from the enlarged, keeled, and strongly imbricate ventrals, the largest middorsals are considerably larger than the ventrals; body slim, no nuchal nor dorsal fold; limbs medium, the adpressed hind limb reaches to between the ear opening and eye; digits slender, pectinate but without dilations; tail slightly compressed, without trace of verticils; the middorsal row of caudals enlarged and with continuous keels; postanal scales very slightly enlarged.

Colour (in life):-Brown, a dorsal stripe of light brown and two lateral white stripes on each side. The dark brown area between the middorsal and upper lateral stripes often cut into a series of squares by narrow and rather faint pale cross-bars. Fore limbs dark brown, hind limbs lighter brown, sometimes distinctly cross barred with darker. In young individuals the middorsal stripe is rarely conspicuous.

$\begin{array}{lr}\text { Dimensions: - Total length } & 89 \mathrm{~mm} . \\ \text { Tip of snout to vent } & 28 \mathrm{~mm} . \\ \text { Vent to tip of tail } & 61 \mathrm{~mm} . \\ \text { Width of head } & 5 \mathrm{~mm} . \\ \text { Fore limb } & 9 \mathrm{~mm} . \\ \text { Hind limb } & 18 \mathrm{~mm} .\end{array}$

The little Cuban grass lizard is found throughout the Island as far west as Guane and is not uncommon in open grassy pastures on dry hillsides and in the more or less sterile savanna land; but from the nature of the country it is not surprising that it should be much more common in central and western than in eastern Cuba. It is abundant in the fallow fields of San Carlos Estate near Guantanamo (Ramsden). In colour it fits admirably with dry grass or canetrash. It is extremely active and is far more often seen than caught. It is 
strictly terrestrial and feeds principally on ants although it will rarely climb even into the lowest bush or upon the stalks of grass to secure its prey; on one occasion the junior author saw one climb about eighteen inches into a small malvaceous bush at Guantanamo. The structure of its feet with the sharp projecting lateral scales marks a transition stage toward the condition seen in such genera as Uma, among iguanids or the South African Ptenopus among geckonids.

\section{Cyclura macleayt Gray.}

Plate 11, fig. 2, 3 .

Iguana.

Diagnosis: - The largest Cuban land reptile, an enormous lizard with prominent gular pouch, a nuchal and dorsal crest of spines and a powerful muscular tail armed with prominent whorls of heavily keeled scales.

Description:-Adult ơ M. C. Z. 11,050. Cuba: Pinar del Rio; Valley of Luis Lazo, April, 1915. Carlos de la Torre and Thomas Barbour.

Rostral as wide as the mental, broadly in contact with nasals; nasal large, somewhat pentagonal, perforated by a large ovoid nostril; each nasal in contact with a large, elongate supranasal and a squarish postnasal; nasals and supranasals broadly in contact on the middle of the snout; the pair of supranasals immediately followed by two pair of large prefrontals, the posterior pair several times as large as the anterior pair; both pairs of prefrontals broadly in eontact in the middle line of the snout; a few granules on the crossing point of the two prefrontal sutures; all these scutes covering the upper surface of the snout slightly swollen and convex; between prefrontals and the scarcely indicated supraocular semicircular two irregular rows of scales, the anterior row formed of scales several times as large as those in the posterior one; immediately following the posterior row a large rounded median scale; supraorbital semicircle differentiated from the supraocular dise but the scales on the outer and anterior portion of the supraocular region smaller than the others; semicircles separated by two, partly by three rows of large scales; occipital located with its posterior end on a line with the posterior end of the semicircle; scales of the occipital region enlarged and swollen, the outer ones largest; about two rows of scales between the occipital and the semicircles; two or three rows of superciliary shields not clearly differentiated, canthus rostralis consisting of three large seales, the first elongate and in contact with two supraciliary scales that are also elongate; all of these seales on the top of the head swollen, slightly keeled, and, 
with the exception of the small supraocular scales, uniformly cnlarged; a welldeveloped series of strongly keeled suboculars continued backward as a supratympanic series; six supralabials to the middle of the eye; a series of three or four rows of small scales separating the supralabials from the suboculars; above the angle of the snout and in front of the lower edge of the eye a large tubercular shield; above it about the middle of the front edge of the ear two large shields, preceeded by a third, all three tubercular; below the angle of the mouth a few tubercular scales, irregularly arranged; five infralabials to the middle of the eye; a single row of very large, keeled malar seales, and two anterior ones in contact with the infralabials, the rest separated from the infralabials by one or two rows of small scales; dorsal and ventral scales small, about eleven contained in the vertical diameter of the tympanum; from the nuchal fold along the median line of the neck and back a row of low, blunt spines, the largest slightly over a centimeter high; this crest interrupted on the shoulders and rump, thirty-seven spines between these two points; upper surface of the limbs with slightly imbricated, keeled, posteriorly pointed scales considerably larger than the body-scales; scales covering the upper surface of the radius and tibia much larger than those covering the humerus and femur; on the upper arm about eight, on the lower about five of these scales to the vertical diameter of the tympanum; a single series of twenty-two femoral pores; inner side of second toe with one comb, of third toe with two combs, each consisting of three lobes; tail compressed, covered with obliquely keeled scales in vertical rows, forming faintly indicated verticils; tail surmounted by a serrated crest similar to the body-crest but formed of slightly larger spines.

Colour (in life):- Ground tone of dorsal surface brownish gray; whole dorsal surface sprinkled with pale, yellowish green, the spots very abundant and partly confluent posteriorly; flanks marked by four broad, vertical stripes of pale bluish gray; each stripe edged dark slaty gray, sides and upper surface of the head broadly blotched with pale bluish yellow; sides of the tail with a series of irregular vertical stripes of bluish gray. becoming regular and evenly spaced posteriorly, ventral surface somewhat. lighter than the upper surface.

$\begin{array}{cr}\text { Dimensions: - Total length } & 910 \mathrm{~mm} . \\ \text { Tip of snout to vent } & 347 \mathrm{~mm} . \\ \text { Vent to tip of tail } & 563 \mathrm{~mm} . \\ \text { Tip of snout to ear } & 73 \mathrm{~mm} \text {. } \\ \text { Width of head } & 52 \mathrm{~mm} . \\ \text { Fore leg } & 156 \mathrm{~mm} . \\ \text { Hind leg } & 254 \mathrm{~mm} \text {. }\end{array}$


A very young specimen, a female measuring only 115 millimeters from snout to vent, collected at Belig, Cabo Cruz, Cuba, by O. Tollin and now in the collection of the junior author, varies greatly in colour from the adult, but the lepidosis of the specimen is very similar to that of the typical adult. In this example the ground tone of the dorsal surface is grayish blue tinged with greenish; along the middle line of the back there is a series of broad white cross-bars edged broadly before and behind with black; these black and white cross-bars are continued on the sides as a series of wavy stripes, each stripe pointing obliquely backward; the ventral surface is paler than the dorsal, and is covered by broken continuations of the lateral stripes.

This species was once a common inhabitant of all parts of the Island. By 1880, however, when Gundlach wrote it had begun to be rare, although he said that it still lived in various cays and about some of the coasts of both Cuba and the Island of Pines. At the present time we have specimens or know definitely that it occurs in the following regions:- near Baracoa (de la Torre), about Guantanamo (the authors) and near Santiago (Wirt Robinson). There is a beautiful young specimen from near Belig, Cabo Cruz, in the collection of the junior author. It is known to occur commonly on the cays of the coast near Manzanillo, Santa Cruz del Sur, as well as those in the Gulf of Batabanó. It is also found on some of the cays of the north coast near Cardenas and Remedios. On the mainland of Cuba it also occurs on the Pan de Guajaibón, in the mountains about the Valley of Luis Lazo and El Sumidero, in the coastal plain about Santa Cruz del Norte, all in Pinar del Rio Province, and probably in some other localities as well. In the Island of Pines, the Iguana is more common than in Cuba. Its tracks and burrows may often be seen in the sand about the coasts and they occur in the Sierras as well. In general it prefers the neighborhood of rocky hills and precipices where there are crevices for hiding and ledges on which it may bask in the sunshine. Iguanas are more often seen than captured, for they are decidedly shy. They may only be secured by shooting or by setting nooses at the entrances to their lairs or hiding places. Gundlach spoke of how they were, in his day, hunted for food; he considered them excellent. Throughout tropical America Cyclura and its allies are eagerly sought and are esteemed highly. At present, however, in Cuba they are generally held in great disgust and often even regarded as poisonous. The country folk often declare that when an Iguana is hung up a drivel or slobber supposed to be poisonous falls from its mouth called the bába or burujo. Possibly this notion is derived from its similarity to the burujo or black vomit which comes 
from the blood-filled stomachs of persons during the last stage of fatal cases of yellow fever. The fact that the Iguanas are growing rare and difficult to obtain coupled with their repulsive appearance may have also contributed to this change of custom. It is strange, however, that so great a change can have taken place in popular opinion in hardly more than a generation.

Key to the Species of Leiocephalus.

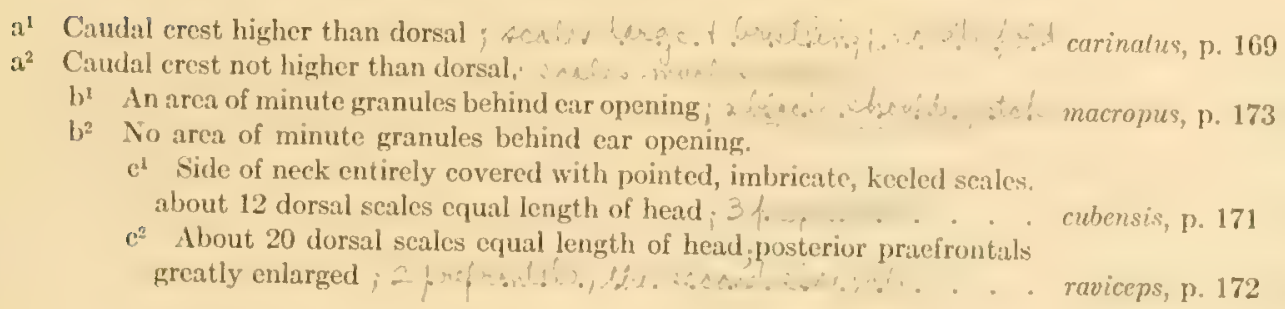

\section{Leiocephalus carinatus Gray.}

Plate 14, fig. 11.

\section{Perico, Caguayo; Iguana de los Fosos; Iguana, Iguuna rabienroscada; Bayoya de rabo enroscado.}

Diagnosis: - A large spiny lizard carrying its tail curled over its back, always when moving and often while at rest. It may be distinguished at once from the other Cuban species by its barred gray and brown colouration and by having the caudal erest better developed than the dorsal.

Description:-Adult M. C. Z. 7,940. Cuba: Morro Castle, Havana, February, 1910. Thomas Barbour.

Upper head-scales, rather large, smooth: nasal in contact with the rostral; supraorbitals extensively in contact; six narrow strap-like supraoculars, separated from the supraorbitals by a single series of rather small scales; two pairs of parietals, the outer pair more than twice as broad as the inner; sides of neck each with two sharply defined, converging folds; scales of sides of neck, pointed, imbricate and sharply keeled; dorsal crest evident but feebly developed; dorsal scales, large, broader than long, slightly mucronate, serrate on their free edges, very strongly keeled, the keels forming continuous and slightly oblique lines; lateral scales slightly smaller than dorsals, imbricate, keeled, the keels much more sharply oblique; ventrals very slightly smaller than dorsals, smooth, rounded, distinctly broader than long; the adpressed hind limb reaches to the 
ear opening; tail somewhat compressed; the caudal crest better developed than the dorsal.

Colour (in life):- Olive-gray or brown; often with lighter cross-bands; the tail strikingly banded above with light and dark. Belly deep olivaceous on the throat, chest and midventral region, fading to yellow posteriorly and on the under surfaces of limbs and tail.

\begin{tabular}{lc} 
Dimensions: - Total length & $200 \mathrm{~mm}$. (A very large adult from \\
& \multicolumn{1}{c}{ Cabo Maisí). } \\
Tip of snout to vent & $112 \mathrm{~mm}$. (Tip of tail lost). \\
Vent to tip of tail & $? \mathrm{~mm}$. \\
Width of head & $22 \mathrm{~mm}$. \\
Fore limb & $42 \mathrm{~mm}$. \\
Hind limb & $77 \mathrm{~mm}$.
\end{tabular}

By far the most characteristic and conspicuous reptile of the marine coast plant associations, where the coast is sandy, is Ameiva auberi, while about rocky shores its place is taken by this bizarre-looking creature. About the gloomy walls of Cabanas Fortress and about the Morro Castles of both Santiago and Havana Leiocephalus carinatus abounds; and both adults and young may be seen during the heat of the day scampering about the bases of the great walls, in the moats and along the sea-cliffs, dodging in and out of the crevices or burrowing under loose stones. As they scuttle briskly about with their tail tightly curled over their backs they look for all the world like tiny pug dogs and have well earned the common Cuban name for them of Perico or doggy. Where there are rocky stretches of coast they abound but they sometimes frequent the sandy stretches as well, scampering about among the great dry leaves of the Beach Grape (Cocoloba uvifera) and making a most startling racket considering their size. Specimens have been collected about the inland outskirts of Havana (Gundlach and Barbour) where they frequent the moats of old forts and similar situations. At Bayamo they are found on the high steep cliffs cut by the river which flows near the city (Gundlach and Barbour). In general, however, it is strictly a coast-land species.

The young are differently coloured from the adults and it is noteworthy that they have the broad maroon-brown lateral band, only with wider white margins, which is so characteristic of many other species of the genus and specially of the Cuban macropus and cubensis. The tail and back are streaked and marbled much more profusely than in either of these two species. 


\section{Leiocephalus cubensis (Gray).}

Plate 14, fig. 12.

\section{Iguana de la Sierra; Bayoya; Arrastrapansa.}

Diagnosis: - The most common and widespread of the curled-tailed lizards having the whole side of the neck covered with imbricating pointed scales (not granules) and having the dorsal and caudal crests about equally developed.

Description:- Adult M. C. Z. 7,281. Cuba: near Camaguey, May, 1909. Thomas Barbour.

Upper head-scales large, heavily striated; nasal in contact with the rostral; supraorbital series broadly in contact; supraoculars four, not conspicuously strap-like, though much longer than broat, separated from the supraorbitals by a series of small scales; two pairs of parietals in a row, the outer pair slightly the larger; sides of neck plicate, covered with slightly elongate, pointed, keeled, and imbricate scales; dorsal scales medium, about twelve corresponding to length of head, heavily keeled and slightly mucronate, the keels in lines sharply turned obliquely toward the middorsal line; lateral seales smaller, the keels not forming such conspicuous lines; ventrals rather smaller than dorsals, smooth and rounded, somewhat broader than long; the adpressed hind limb reaches about to the ear; tail somewhat compressed, with a caudal crest about equally developed with the dorsal.

Colour (in life):- The back rich mahogany-brown, in young and halfgrown examples, variegated with series of dark dots. A broad black band on each side of the head which changes to a rich maroon-brown upon the sides of the neck and gradually becomes less distinct posteriorly upon the sides. In the young these bands are very conspicuous and are narrowly edged with white. The white edging of the lower margin of the lateral band is usually present through life. The throat is usually flecked with white or grayish or reddish ground-colour which becomes paler posteriorly until it is dirty yellow about the thighs and vent. The tail is brown, lighter boward the tip, narrow and inconspicuous dirty yellow bands.

$\begin{array}{lr}\text { Dimensions: - Total length } & 240 \mathrm{~mm} . \\ \text { Tip of snout to vent } & 90 \mathrm{~mm} . \\ \text { Vent to tip of tail } & 150 \mathrm{~mm} . \\ \text { Width of head } & 14.5 \mathrm{~mm} . \\ \text { Fore limb } & 37 \mathrm{~mm} . \\ \text { Hind limb } & 67 \mathrm{~mm} .\end{array}$


This is the most common member of the genus in Cuba and the most widely distributed. It occurs from Cabo San Antonio to Cabo Maisi but usually in the lowlands or in the less elevated limestone ranges. About Guane and the Valley of Luis Lazo it is called La Iguana de la Sierra, not because it is really confined to the Sierras thereabouts but because the peasants believe that the sounds heard by night from the hills and really the tinkling voices of the Ranitas (Eleutherodactylus) are made by these lizards which live in or have retired to the Sierras to pass the night. About Matanzas the same sounds are attributed to the Coronel (Anolis lucius). Generally L. cubensis is most abundant about the edges of cane-fields and in the guarda rayas which divide them. They are extremely abundant in the Botanical Gardens in Havana and on railway embankments near Camaguey, where one may find, we believe, the largest specimens on the island. The tail is very often carried curled, but sometimes only for the distal third or fourth as in the other species of the genus and less tightly and less constantly than in L. carinatus.

This species has been widely known as L. vittatus (Hallowell) but as Stejneger notes (Proc. U. S. N. M., 53, p. 273) the name Leiocephalus cubensis Gray is applicable to this species and is earlier.

\section{Leiocephalus raviceps Cope.}

Plate 10, fig. 4.

Diagnosis:- A small curled-tailed lizard having but two pairs of prefrontals, the posterior pair conspicuously enlarged.

Description:-Adult M. C. Z. 10,928. Eastern Cuba. Charles Wright. (A cotype from U. S. N. M. 4,162).

Upper head-scales large, bi- or tricarinate or rugose; nasal widely in contact with rostral; supraorbital series broadly in contact; six or seven supraoculars, rather strap-like, separated from the supraorbitals by a series of small scales; two pairs of parietals in a row, the outer pair slightly the larger; sides of neck plicate covered with rather small, rounded, keeled and imbricate scales; dorsal scales small, about twenty-one or twenty-two corresponding to length of head, heavily keeled, very slightly mucronate and strongly imbricate, the series of keels turning slightly toward the median line; ventrals decidedly larger than dorsals, smooth, rounded, broader than long; the adpressed hind limb reaches almost to the eye; tail slightly compressed with but a trace of a caudal crest. 
Colour (faded alcoholic specimen):-Brown above with two series of black dots on each side of the middorsal line; sides with a darker brown band from cheek to groin bordered above with seattered light specks and below by a conspicuous white line; lower surfaces whitish.

$\begin{array}{cr}\text { Measurements: - Total length } & 125 \mathrm{~mm} . \\ \text { Tip of snout to vent } & 53 \mathrm{~mm} . \\ \text { Vent to tip of tail } & 72 \mathrm{~mm} . \\ \text { Greatest width of head } & 9 \mathrm{~mm} \text {. } \\ \text { Tip of snout to ear } & 11 \mathrm{~mm} \text {. } \\ \text { Fore limb } & 20 \mathrm{~mm} . \\ \text { Hind limb } & 33 \mathrm{~mm} \text {. }\end{array}$

Boulenger (Cat. lizards B. M., 1885, 2, p. 163) made this species a synonym of Leiocephalus vittatus (= cubensis), a course followed by the senior author when no specimens were at hand (Mem. M. C. Z., 1914, 44, p. 301). Stejneger (Proc. U. S. N. M., 1917, 53, p. 274) maintains that raviceps is a distinct species and having now one of the types in the M. C.Z., we agree that it is surely distinct. We feel, however, that its being Cuban is by no means so certain. Wright collected most if not all his reptiles at Monte Verde, an old coffee p!antation in the Sierra de Yateras. This region has been worked for many years by the junior author, but neither he nor any other collector has succeeded in finding the species here or elsewhere in Cuba. Throughout its entire range, the genus is by reason of its habits rather conspicuous and easy to collect. Stejneger points out that its true relationships are with L. loxogrammus; we have compared M. C. Z. 10,928, with a type of loxogrammus M. C. Z. 10,931 and with three other specimens of the species, M. C. Z. 6,230, all from Rum Key. They are much alike but not identical, the posterior of the two pairs of prefrontals being still much larger in the latter than in raviceps. All things considered, it is by no means impossible that the types of raviceps came from some one of the Bahamas and were credited to the Wright collection from Cuba by mistake.

\section{Leiocephalus macropus Cope.}

Plate 10, fig. 5 .

Bayoyai Arrastrapansa.

Diagnosis: - An iguanid lizard which carries its tail coiled over its back while running, with smooth ventral seales and having an area of fine granular scales posterior to the ear opening. 
Description:- Young M. C. Z. 10,928. Cuba: (?Monte Verde). Charles Wright. (A cotype from U. S. N. M.)

Upper head-scales rather large, striated; nasal in contact with the rostral; supraorbitals widely in contact; supraoculars six, the middle two or three straplike, separated from the supraorbitals by a row of small scales; parietals in two pairs, the outer pair rather the wider; sides of neck strongly plicate, a distinctly defined area of granular scales behind the ear opening; dorsal crest very low; dorsal scales very slightly mucronate, the keels tending obliquely toward the middorsal line; laterals smaller than dorsals, ventrals about the same as dorsals in size but smooth, rounded and broader than long; adpressed hind limb reaching to between eye and nostril; tail slightly compressed; crested like the back.

Colour (in life):- Above olive-brown, rich and lustrous, with a burnished sheen or polish, (not iridescent); usually a transverse dark brown interscapular and sacral spot; a rich maroon band extends from orbit to groin often edged with whitish and dotted with white in axilla and groin; lower surfaces yellowish or greenish white.

\section{Dimensions:- Total length}

Tip of snout to vent

Vent to tip of tail

Width of head

Fore limb

Hind limb
$190 \mathrm{~mm}$. (M. C. Z. 11,208 from

Baracoa).

$70 \mathrm{~mm}$.

$120 \mathrm{~mm}$.

$14 \mathrm{~mm}$.

$31 \mathrm{~mm}$.

$64 \mathrm{~mm}$.

There is a great variation within this species in the arrangement of scales on the fore head and snout.

The species is confined to the Province of Oriente. Just what are the limitations of its range cannot be described. The senior author did not find it in the Sierra Maestra near Baire and Jiguaní but farther east in the mountains of Oriente collected it upon Monte Libano near Guantanamo and it has been taken in most of the highlands as far north as Sagua de Tánamo (Ramsden). Wirt Robinson secured a series in hills near Santiago in 1903 and recently de la Torre and Rodriguez have sent the M. C. Z. a number from the neighbourhood of Baracoa. It is distinctly a highland species, its place in the lowlands and cane-fields being taken by $L$. cubensis, although the latter is far more abundant in the central and western districts of the Island.

It is shy and rather wary, rushing off, scuttling away among the leaves with its tail tightly curled above its back after the manner of its congeners. 
ANguidat.

49. Celestus de la sagra (Cocteau).

Plate 14, fig. 13.

Culebrita de cuatro patas.

Diagnosis: - A smooth cylindrical shiny burrowing lizard with short, degenerated limbs and small weak toes.

Description:-Adult M. C. Z. 7,924. Cuba: near Havana, Spring of 1910. Jesús Valdivia.

Rostral oblong, rectangular, almost invisible from above, followed by a pair of supranasals well in contact; a pair of frontonasals larger than the supranasals, also broadly in contact; prefrontal large, undivided, with an obtuse projecting angle in front and a straight border behind forming a suture with the entire anterior border of the frontal; frontal squarish, longer than broad, longer than the distance between the supraoculars; a postfrontal, or frontoparietal, plus another small shield separating the supraoculars from the parietals on each side; parietals large, separated from each other by a nearly triangular interparietal and a rather large diamond-shaped occipital; five supraoculars; a single nasal in contact with the rostral, the nostril being pieced in the posterior half; three loreals in a row between nasal and preocular, first in contact with frontonasal only, second with frontonasal and prefrontal, third in contact with prefrontal, first supraocular and a superciliary as well as preocular; a long angular subocular wedged between and separating widely the fifth and sixth supralabials; eight supralabials; three large temporals in the first row forming a semicircle behind the eye; mental very small, narrower than rostral, followed by a large median postmental; four large chin-shields, the first two in contact with the infralabials; car opening small, round, about the size of the first supralabial, body elongate, the distance between the tips of the adpressed fore and hind limbs being far greater than the distance from tip of snout to arm; thirtyfour scales around the body, dorsals finely striated, laterals smooth; fore leg shorter than distance of tip of snout from ear opening; five fingers, all short, third longest; hind leg short; five short toes, fourth longest; tail long, cylindric, (ending in a point), covered with scales like those of body, the two median rows beneath very slightly enlarged.

Colour (fresh in alcohol): - Above grayish brown; a dark lateral longitudinal band, consisting of a distinct dark line along the upper part of the side 
with a zone of dark specks below it. These fleckings grow fewer and the groundcolour becomes lighter ventrally until the colour of the lower sides merges into the yellowish cream-colour of the belly.

This species like its congeners probably varies very little in squamation. An adult example (M. C. Z. 7,426) from eastern Cuba, Charles Wright collector, is exactly like the specimen described, except that on one side three chin-shields are in contact with three infralabials. Although this is an old specimen it is very well preserved and shows an entirely different colouration. The back and side are rich walnut-brown; the back is heavily spotted and flecked with darker; the dark side-line is present but not very conspicuous, the sides also are heavily spotted and washed with brown, the belly is yellowish.

Neither of these specimens is perfect. Boulenger gives the following measurements:- total length $201 \mathrm{~mm}$., tail $114 \mathrm{~mm}$. M. C. Z. 7,426 measures $90 \mathrm{~mm}$. from snout to vent, while the tail with a considerable portion of the tip missing measures $120 \mathrm{~mm}$; thus it would appear that Boulenger's measurements, which are not original, as there was no specimen in the British Museum, were probably taken from a specimen with the distal portion of the tail reproduced. In this genus the reproduced tails are sometimes grown with squamation so much like the rather generalized type seen on the original member that it is difficult to recognize the reproduced part. This is never the case with forms in which the tail scutellation is ornamented. Under such circumstances the new growth shows a scutation of a much simpler type - whether ancestral or not is impossible tosay. Recently we have examined a perfect specimen (Ramsden collection) from Los Hondones, Guantanamo, in which the body from snout to vent measured $85 \mathrm{~mm}$. and the tail $115 \mathrm{~mm}$.

Little or nothing is known of the habits of any of the Antillean Celesti. They are nowhere common and are only found by the collector by the merest chance under stones or hidden in similar situations. Hitherto nothing has been recorded regarding their breeding habits. In June, 1914, however, the junior author found a male Celustus under a stone near Belona, not far from Guantanamo, Cuba. He was lying over five eggs and when disturbed made no effort to eseape, simply hiding his head as if for protection. This makes it appear probable that the male may remain on guard near the eggs until they are hatched. The eggs which have a very soft shell measure $9 \times 17 \mathrm{~mm}$. As in Jamaica where Celesti are called "Galliwasps," and considered very deadly, so also the Cuban species is feared but to a far less extent. In Jamaica there are several spceies, making the members of the genus more common, hence more widely 
known, while in Cuba, since there is but a single species and that a very rare one, there are but few, and those only among the more observant country people, who know and fear it.

The locality records for the comparatively few specimens which have reached museums and which have borne full data make it appear that the spccies occurs throughout the Island.

\section{XANTUSind F.}

50. Cricolepis typica (Gundlach \& Peters).

Plate 4, fig. 2; Plate 11, fig. 1.

Diagnosis: - A very small, short limbed ground-lizard; with a long fleshy tail; large plate-like scales on the head and extremely small, even, rounded scales in transverse series all over the upper surface of body, and series of squarish scales on the tail; lower surfaces with rows of larger scales.

Description:- Adult M. C. Z. 8,512. Cuba: Cabo Cruz, near the lighthouse, Spring of 1913. Thomas Barbour.

Rostral pentagonal forming an obtuse angle behind; nostril pierced between two nasals; anterior nasals in contact behind the rostral; a pair of squarish frontonasals and a similarly shaped pair of slightly larger prefrontals; frontal large, heptagonal, the posterior region expanded; four supraoculars, first very small, third largest; a large interparietal with straight edge next the frontal, bulging or rounded sides and an obtuse angle behind; a small frontoparietal on each side, between the supraoculars, the frontal, the interparietal, and a large temporal, which forms a suture with the interparietal and the parietal; two loreals, second larger; temporal region with slightly enlarged flat scales of irregular shape, mosaiced in a pavement-like manner; seven upper labials; mental a trapezoid, followed by a heptagonal postmental and three large chinshields on each side, the first pair forming a long suture; lower labials about equal in size to upper. A strong ring-fold separates head from neck; the gular scales anterior to the fold slightly enlarged, flat, squarish to roundish, those between the fold and collar generally roundish and slightly less flat. Scales of upper surfaces small, equal, granular in transverse series; ventrals much enlarged, square, forming eight (six large and two smaller) longitudinal rows and twenty-six transverse series. Four square preanals, posterior pair larger. Limbs weak; digits short with two rows of minute tubercular scales 
below. Eight femoral pores on each side. Tail fleshy cylindrical, tapering to a fine point, longer than head and body; caudal scales squarish or oblong, verticellate, considerably larger below.

Colour (in life):- Upper surface of body reddish brown, a light line along the upper region of each side; sides of body more dusky brown. Tail bright brick-red above, almost vermilion below. Belly yellowish.

$$
\begin{array}{cc}
\text { Dimensions: - Total length } & 92 \mathrm{~mm} . \\
\text { Tip of snout to vent } & 32 \mathrm{~mm} . \\
\text { Tail } & 60 \mathrm{~mm} .
\end{array}
$$

Gundlach collected the types of this species under stones at Cabo Cruz in 1857. From that time until in 1913, when the senior author visited the same spot, no specimens found their way into any collections. Since 1913, Mr. Oskar Tollin has visited the same general region and discovered the species at Belig, not far from the Cape. Gundlach in his MS. note-book now in Prof. de la Torre's possession describes very exactly where he collected, but made no special comment except that they were found under stones. The senior author who was at the Cape during a rather cool dry spring found the species rare; Tollin, on the other hand, was at Belig during the rains in August and found a considerable number of individuals under decaying leaves on the forest floor. Tollin's specimens are in the collections of Prof. de la Torre of Havana, the Carnegie Museum at Pittsburgh, and the junior author; the remaining great majority of the specimens are in the collection of the M. C. Z., whence examples have been sent to the U. S. N. M. and to the British Museum. There is no record of the number Gundlach obtained, there is but one in the Museo Gundlach of the Institute of Secondary Education at Havana, and others are doubtless in the Berlin Museum, since they were sent to Peters.

Thus we know nothing of the life history of this curious archaic lizard. Its allies Xantusia and Lepidophyma are nocturnal and although probably far from rare are nevertheless represented in but a few museums. This species and Solenodon cubanus are zoölogically the most curious and interesting inhabitants of Cuba and any notes or data regarding their life histories would be very valuable. 


\section{TeIIDAE.}

\section{Ameiva auberi Cocteau.}

Plate 14, fig. 14.

Corre-costa; Culebrina (Santiago de Cuba).

Diagnosis: - An olivaceous brown ground-lizard generally with three narrow light stripes on the back, and a broad dark lateral stripe on each side. A shy and swiftly moving species, with an acutely pointed head and a very long round tail.

Description:-Adult ơ M. C. Z. 7,277. Cuba: Camaguey, 1908. Thomas Barbour.

Rostral forming a little more than a right angle behind; nostril on the posterior edge of the anterior nasal; anterior pair of nasals broadly in contact behind the rostral; frontonasal as long as wide, in contact with the loreal; prefrontals broadly in contact; frontal in contact with the first and second supraocular; a pair of frontoparietals in contact with the third supraocular for nearly their entire length; five occipitals in a transverse row, the two in contact with the median, largest; seven supraciliaries; three supraoculars, the first separated from the loreal; two posterior supraoculars separated from the supraciliaries by a double row of granules; last supraocular separated from the outer occipitals by three rows of small scales; seven large supralabials; five large infralabials; between the infralabials and chin-shields a wedge of one to three rows of granules extending anteriorly to the first chin-shield; chin and throat covered with granules, an indistinct band of very slightly larger ones extending across the middle, the median ones forming an ill-defined central group of slightly enlarged scales; on the area between the two throat-folds several rows of large hexagonal scales; under side of the body with ten longitudinal and thirty-five transverse rows of plates; preanal plates, two anterior median and three posterior marginal ones; on the lower arm a double row of antebrachials, one much wider than the other, both decreasing in width towards the elbow joint; on the upper arm a similar but narrower single row of brachials continuous with the antebrachials; on the posterior side near the elbow a small group of enlarged postbrachials; under side of the thighs covered with six or seven series of hexagonal plates of which the outer series is considerably larger than the others; thirteen and fourteen femoral pores; on the under side of the 
tibia two rows of plates, those of the outer rows enormously enlarged; upper side of the wrist with a regular series of transverse plates corresponding to the inner and outer metatarsals; outer toe extending approximately as far as the inner; tail covered with straight scales with keels; about thirty-five scales in the fifteenth ring from the base.

Colour (in life):- Ground-colour of dorsal surface olivaceous brown, slightly reddish anteriorly, grayer on the tail; three poorly defined narrow stripes of a lighter colour on the back; the two lateral stripes bordered on their outer side by a series of broad, dark brown spots which tend to become confluent; the same two outer pale stripes are bordered on their inner side by a poorly defined and much lighter series of similar dark spots; flanks, sides of head, sides and upper surfaces of the tail and appendages covered with a network of irregular brown patches; ventral surface straw-colour; traces of the same colour on the head-shields.

In this species the females show almost exactly the same colouration as the males. There is, however, considerable individual variation in the extension and distinctness of the dorsal stripes. There is also some variation in the distance by which the gular scales are separated by granules.

The Cuban Ameiva is found everywhere in the Island except in the swampy regions, especially back of sandy beaches. We have examined and compared examples from Guane, Cojimar, San Diego de los Baños, Bahia Honda, Cienfuegos, Camaguey, Santiago, and Guantanamo. No examples were ever observed in the Zapata swamp, nor in similar regions such as the swampy coastal plain from Palo Alto near Jucaro to the Estero de Juan Hernandez.

Since this lizard is extremely shy and correspondingly quick in hiding, it is not seen moving about as often as its abundance would warrant. It is gencrally found under stones or such rubbish as fallen palm fans and logs, which provide suitable hiding places. Occasionally, however, they may be seen crawling about, usually in the dryest and most sunbaked places, with decorous preoccupation and leisurely picking up ants. In the spring of 1909 they were really abundant on the hot stretches of cinders and ballast along the line of the Cuban railway, just west of the city of Camaguey and a number could be seen there any day when the sun was high. 
Ampuisbaenidae,

52. Cadea blanoides Stejneger.

Plate 15, fig. 1.

Culcbrita ciega.

Diagnosis:- A thick, rather short, eyeless, legless lizard. In colour ashy gray washed with a rosy pink iridescence and with small darker spots. It is noteworthy in having no lateral line.

Description:- Adult M. C. Z. 7,934. Cuba: San Diego de los Baños, March, 1910. Thomas Barbour.

Snout rather acute, rounded at the tip, projecting rery slightly beyond lower jaw; rostral medium, rectangular, higher than broad, forming a long suture with prefrontal; prefrontal single, large, longer than broad, roofing the snout; two long narrow frontals, followed by two pairs of small squarish occipitals; eye almost invisible; an elongate supraocular reaching forward to the nasal; three upper labials, first very small, second very large, third medium; mental squarish, followed by a long postmental, three lower labials, first small, other two very large; annuli, dorsal, 221, annuli, ventral, 182; annuli on tail, dorsal, seventeen; annuli on tail, ventral, fourteen; an annulus about the middle of the body contains thirty-three segments; dorsal segments oval, ventral rectangular, broader than long; no lateral line; anal segments eight; praeanal pores, eight.

Colour (in life):- Gray with a flesh coloured or peach-blow bloom or iridescence; most of the dorsal segments with a dark central spot.

$$
\begin{aligned}
& \text { Dimensions:- Total length } 224 \mathrm{~mm} \text {. } \\
& \text { Vent to tip of tail } 17 \mathrm{~mm} \text {. }
\end{aligned}
$$

This is the species which has figured for many years in the literature as Amphisbaena punctata Bell. Stejneger (Proc. Biol. soc. Wash., 1916, 29, p. 85) has shown that it is, first, not an Amphisbaena and also that Gray was entirely justified in making the genus Cadea to include it. He also points out that A mphisbaena punctata Bell, 1828, is preoccupied by A. punctata Wied, 1825, and he substituted the specific name blanoides, by authority of one of the least justified canons of the International zoölogical code of nomenclature. Certainly Cadea punctala would not be confused with Amphisbaena punctata if the two names were in present use. 
Cadea blanoides is rare in Cuba, far more so than is Amphisbaena cubana. The only specimens which we have seen are from the west, Herradura, Guanajay, and San Diego de los Baños, and we believe that it does not occur east of Havana. It is a very beautiful species in life. The few specimens obtained were dug from the soil in preparing gardens for vegetable planting.

The remarkable species Cadea palirostrata Dickerson is known only from the Island of Pines. It is interesting in that the head is flattened in a vertical plane to aid in burrowing. Although Cadea blanoides is as yet unknown from the Island of Pines and although the fauna of the Island is entirely made up of the identical, or more or less slightly modified, representatives of Cuban species, it seems hardly possible that this form can be the local homologue of C. blanoides; it is so much more differentiated than any other of the Island of Pines representatives of Cuban species. Cadea palirostrata may possibly be quite unrelated to $C$. blanoides, and in that case it may surely be looked for in Cuba as blanoides may be in the Island of Pines. Four specimens, one now M. C. Z., were collected at San Pedro, Island of Pines, by Charles S. Meade in 1911. To aid in recognizing this species, the following extract from the original description is added:-

"Mouth inferior, muzzle extending beyond it a distance equal to the length of the nasal. Muzzle long and pointed. Head compressed with spadelike ridge extending dorsally from occipitals forward, and ventrally the length of the mental. Rostral large, compressed and extending in a conspicuously convex band forward and upward over the end of the muzzle, and backward to an angular suture with the praefrontal - thus adding to the adaptability of the head for digging. Praefrontal relatively large, its width little less than its length, compressed and folded over the dorsal ridge of the muzzle, indented anteriorly by the entrance of the rostral, and posteriorly by the two frontals. The latter equal in length to the praefrontal, widest in the middle. Frontals followed by a pair of subquadrilateral occipitals. Eye visible under the anterior angle of the ocular. Nostril pierced in the middle of the anterior end of the nasal. Supraocular very elongate, forming sutures with nasal, praefrontal and frontals, second labial, ocular and parietals. Three upper labials subequal, although of greatly varying shape; first slightly smallest, second slightly largest. Mental subquadrilateral with short winglike extensions anteriorly, and in the midline anteriorly compressed into a short downward-projecting wedge; chin shield nearly twice as long as mental, broadest near the anterior end; three lower labials, the first small, the second very large, twice as large as the second upper labial. Annuli, dorsal, 329; ventral, 286. Annuli on the tail, dorsal 21; ventral, 16 . Annulus on the middle of the body contains 39 segments. Dorsal segments narrow, oval; ventral, slightly broader than long, square-angled. No lateral line. Anal segments, 10; praeanal pores, 10. General coloring brownish, darkest on head, lightest ventrally - each segment with one or more irregular brown blotches, varying in position on the segments.

"Type: Length to vent, $280 \mathrm{~mm}$; t tail, 15." Dickerson, Bull. Amer. mus. nat. hist., 1916, 35, p. 659 . 
Since this was written any doubt which may have existed as to the accuracy of the data regarding the locality of the types of this species has been removed, for Messrs. Brooks and Warner captured a fine adult at McKinley, Island of Pines, in March, 1917. Later during 1918 the senior author and Mr. W. S. Brooks took a very large series, every one a typical palirostrata; it was also found abundantly in several localities in the Island of Pines, namely La Ceiba, Santa Barbara, and McKinley. These were found when the fields were ploughed. The senior author also found several blanoides by following ploughs on the plantation of Mr. Shaler Williams at Caimito del Guayabal, near the town of Guanajay. Thus it is evident that each of these species is peculiar to its original locality and some unknown cause has given rise to their surprising differentiation into full species, whereas most of the Island of Pines forms are but ill-defined local races.

53. Amphisbaena cubana Peters.

Plate 15, fig. 2.

Culebrita ciega.

Diagnosis: - A rather small and slender, blind, legless lizard with a lateral line on each side separating the dorsal from the ventral scutation. In colour, brown uniform or dotted.

Description:-Adult M. C. Z. 7,936. Cuba: Soledad near Cienfuegos, February, 1910. Thomas Barbour.

Rostral small, triangular, barely visible from above; prefrontals long, the suture between them much longer than the one between the frontals; ocular fused with second supralabial (as is invariably the case in our Cuban series), postocular rather large and squarish; a well-developed diamond-shaped temporal; eye plainly visible; a pair of occipitals almost square, in contact behind the frontals; three supralabials, first small, the second enormous since it includes the ocular, third medium sized; three lower labials, the first and third small, the second very large indeed; mental followed by a large median postmental diminishing in breadth anteroposteriorly; behind the postmental and between the enormous second sublabials are two large oval shields including three small scales, one ahead and two behind, between them; these followed by five ventral contour seales between the malars which are set just inside of the third infralabial, and which are also broadly in contact with the second infra- 
labial; rings on the body 204, rings on the tail fourteen; the segments of each ring longer than broad on the back, broader than long on the belly, fourteen above and sixteen below the lateral line; anal shields, eight; preanal pores, five (normally and almost invariably four).

Colour (in life):- Rather light brown, almost all of each segment being covered by a square dark brown spot. These spots appear on but a part of the ventral segments, giving the body a mottled appearance. Head uniform brown.

$$
\begin{array}{cr}
\text { Dimensions: - Total length } & 194 \mathrm{~mm} . \\
& \text { Vent to tip of tail } \\
14 \mathrm{~mm} .
\end{array}
$$

Like all West Indian amphisbaenians, A. cubana has always been rare in museums. Boulenger had no specimens when he wrote the British Museum Catalogue and presumed that the species was really the same as caeca from Porto Rico, as he considered the fusion of the ocular with second supralabial, although present in both types, to be an anomaly. Stejneger recorded two other specimens showing this same curious character and concluded in his Herpetology of Porto Rico (1904) that the species was valid. That Stejneger is correct has been shown by the very large series collected by the senior author in 1910 at Soledad, and another series equally large received in 1915 from Mr. R. M. Grey of the Harvard Botanical Station. The species can be secured in numbers by persistently following the ploughman at work preparing the canefields for replanting. The securing of a series is merely a matter of time. Although many specimens of Typhlops lumbricalis and of Leimadophis andreae were secured in this same way, no specimen of Cadea was ever found near Soledad. Following ploughs in other parts of the Island has not been equally successful and none were obtained at Señor Francisco Morales's plantation near the Rio Hanabana in the Cienaga de Zapata. Although apparently so locally distributed the species, nevertheless, has very considerable range, for the U. S. N. M. has received it from Matanzas far to the west of Cienfuegos, while specimens have been collected on the plantation of San Carlos near Guantanamo in extreme eastern Cuba (Ramsden) and near Havana (Barbour). In January, 1917 a few were found under stones on the floor of a heavy lowland forest. This was while enjoying the hospitality of Mr. Walter Wilcox whose mahogany cutting is on the east shore of the Ensenada de Cochinos, at Caleta Rosario (Barbour). Young specimens, but three or four inches long and very slender, are by no means rare, but so far we have no information regarding the egglaying or breeding habits in general of either of the Cuban amphisbaenians. 


\section{REP'ILIA: SERPENTES.}

Key to the Genera.

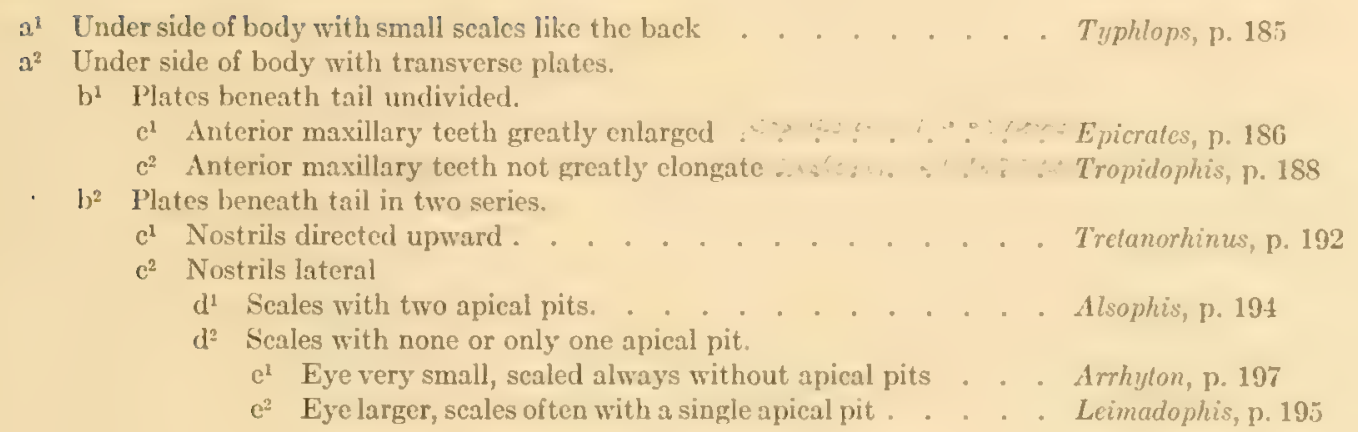

\section{Typhlopidae.}

\section{Txphlops LUMbricalis (Linné).}

Plate 11, fig. 4, 5.

Culebrita ciega; Vibora.

Diagnosis:- A small burrowing snake (not to be confused with the Cuberita ciega, amphisbaenid lizards), with smooth nearly cylindrical body, covered with rounded imbricate scales almost alike above and below; the eye is hidden under a large shield but may show through as a black spot; it is often quite invisible.

Description:-Adult M. C. Z. 10,855. Cuba: Havana Province; San Antonio de los Baños, March, 1915. Thomas Barbour.

Head depressed, snout projecting, rounded on the sides; nostrils just below the lateral edge; rostral between two and three sevenths of width of the head; nostril over the second supralabial suture; ocular with but slightly convex anterior edge, in contact with third and fourth supralabials; supraocular, prefrontal, frontal, postoculars, and parietals scale-like and subequal; eye visible; twenty rows of scales around the body; about 367 scales on the midventral line from chin to vent, twelve scales on lower middle line of tail; tail ending in a spine.

Colour (in life): - Dark gray-bromn, each dorsal scale with a darker basal spot, seales of sides lighter unspotted. Lower surfaces yellowish white. 


\section{Dimensions: - Total length \\ $182 \mathrm{~mm}$ \\ Vent to tip of tail \\ $5 \mathrm{~mm}$. \\ Diameter of body \\ $7 \mathrm{~mm}$}

The common Antillean blind snake is one of the most widely if not the most widely distributed reptile of the whole West Indian area. It has been found upon the South American mainland and upon Jamaica, Haiti, Mona, Porto Rico, St. Thomas, St. Croix, St. Kitts, Antigua, Guadeloupe, Dominica, Martinique, as well as upon several of the Bahamas and Cuba.

In Cuba it is abundant and widely distributed. Living entirely in subterranean burrows it is but rarely seen except. when perhaps a heavy rain has forced its unwilling appearance on the surface of the ground. It may be found readily by following a plough or by digging in gardens or turning over logs and stones. It is found in the high mountains equally abundant as in the lowlands and in both wild and cultivated terrains. It is widely feared by the peasants, being supposedly poisonous, a senseless notion perhaps arising from the caudal spine looking a bit like a sting. The Cuban Guajiro knows the scorpions only too well and probably fears all tails bearing apparent stings.

\section{BOIDAE.}

\section{Epicrates ANgulifer Bibron.}

Plate 15, fig. 3.

Majá de Santa Maria.

Diagnosis: - A very large constricting serpent, aggressive when disturbed. The body covered by many rows of small scales, the lips with rudiments of a series of pits. The colour iridescent brown with dorsal rhombs of darker, and with lateral ocelli having yellowish centres.

Déscription:- Young M. C. Z. 960 Loc.?

Judging from its date of receipt and character of label this specimen was received by Prof. Louis Agassiz from Prof. A. Aug. Duméril of Paris and is probably one of the types of the species. Duméril spoke of sending only "types" to Agassiz - but "types" as the word was then used did not, to be sure, invariably refer to "types" in the sense of present usage.

Head with somewhat irregular, pavement-like scales; a pair of large prefrontals are conspicuous, a rosette of seven scales, one central and six peripheral upon the frontal region, a supraocular both separated from the supralabials 
by a series of small scales; a series of five or six small shields behind and below the eye; the eye thus wholly separated from the supralabials; thirteen or fourteen upper labials with a faint trace of pits. Scales in fifty-nine (may be 51-65) rows, ventrals 280 (276-300), anal entire; subcaudals sixty-four (50-85).

Colour (in living specimen): - Pale hazel-brown with a beautiful iridescent play of colour; on the middorsal region a series of dark rhombs, on the sides series of ocelli of dark brown with yellow centres. There are various other spots and marks of dark colour between these conspicuous markings. Belly yellowish.

\section{Dimensions: - Total length (adult fide Boulenger) $2170 \mathrm{~mm}$. Vent to tip of tail $195 \mathrm{~mm}$.}

The Cuban Boa is still by no means rare but with the increasing cultivation of the country large individuals become more and more difficult to find. Gundlach records specimens from the Cienaga of seven yards and had one himself of five yards, which is probably the one now stuffed in the Museo Gundlach. A specimen of almost this size was received some years ago alive at the New York Zoölogical Park and was a most extraordinarily bulky reptile. A living Boa about nine feet long was caught in the Cienaga in 1915 and two others in 1913 of about the same size (Barbour). Examples over ten feet long are certainly rare today, although the junior author has seen a skin over twelve feet long with head and neck cut off. Then one attempts the capture of a Maja the snake is invariably found to be of the most irascible and snappish disposition. In habits the species is a typical Boa, sluggish and retiring, but it seems to be much more terrestrial than the Central and South American species. Gundlach records the young, which are born alive, to be twenty-one inches in length. Before shedding the Majá loses the brilliancy of its colouring, as with the other iridescent reptiles, but after shedding it is most beautiful and the play of colours rivals an opal in effect. The Maja is much persecuted by the country folk because of its destruction of chicken, turkeys, and young pigs. Palmer and Riley notice that about the bat caves of Guanajay the Boas were said by the country folk to take their station at the mouth of the caves and by lunging forward to catch bats from the stream which pours forth just after dusk. Rather loath to believe this the senior author visited the caves of Guanajay in 1910 and found the bones of many bats about the opening of the caves but decided that probably they had been killed by barn owls. That the legend which is quite widespread was probably true, however, is proved by the following short 
narrative from a wholly trustworthy observer, Señor V. J. Rodriguez, Assistant in the Museo Poey at the University of Havana:-

"Once while exploring near Maisí we entered a cave which had just inside the entrance a large salon. From this a narrow passageway led to a second hall, the passageway greatly narrowed by two huge boulders which had fallen in. On entering the second room we heard a noise and upon further examination found that the whole floor of the cave was one seething mass of enormous cockroaches and that the noise was the result of the rubbing of one with another as they struggled about. Large centipedes were moving back and forth across this living floor. Our lights showed a veritable inferno in miniature. Bats flew about in great clouds, the stench was overpowering and the chambers still further in were so fearfully hot that no entrance was possible. On our way out in the narrow passage between the first two halls a large majá was ensconced in a hole at about the level of one's shoulder and with several feet of his body projecting he was making vicious lunges at the passing and repassing bats which we had stirred up. We finally got him by the neck and with some labour hauled him free and bagged him."

\section{Key to the Species of Tropidophis.}

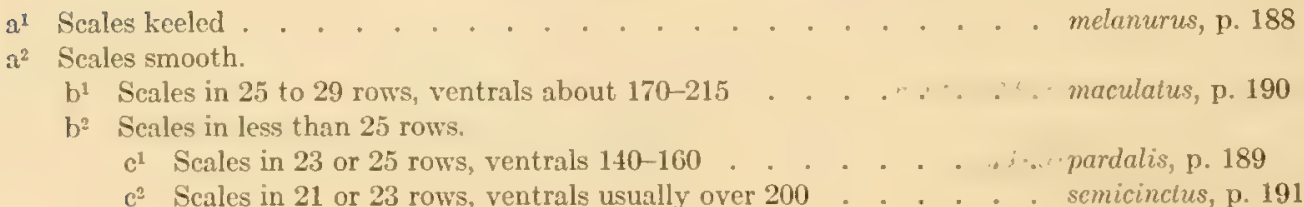

\section{Tropidophis melanurus (Schlegel).}

\section{Majá; Culebra boba.}

Diagnosis: - The largest member of the genus, a sluggish constrictor, like its congeners with vertical pupils in the eyes, usually corn-colour, or light grayish and with the scales strongly keeled.

Description:- Adult M. C. Z. 10,835. Cuba: Piñar del Rio; Guane, February, 1915. Thomas Barbour.

Head very distinct from neck; rostral much broader than deep, just visible from above; frontal longer than broad, a little shorter than its distance from rostral; parietals not very conspicuously differentiated; one pre- and three postoculars; nine upper labials, fourth and fifth entering the eye; scales in twenty-seven (sometimes twenty-nine) rows, distinctly keeled except the three outer rows (sometimes four or five) which are smooth; ventrals 220 (range 200-225); anal entire; subcaudals forty-two (range 30-45).

Colour (in life):- Varying shades of corn-yellow, reddish and ashy gray 
with darker vertebral blotches which often have irregular light centres. There are scattered dots of dark brown upon the sides and belly, sometimes almost wholly wanting. There are sometimes more or less conspicuous dark streaks along the side of the body, a light streak near the angle of the mouth and often a dark vertebral line. In spite of the name neither Gundlach nor we have seen an individual with a black tail.

$$
\begin{aligned}
& \text { Dimensions: - Total length } \quad 670 \mathrm{~mm} \text {. } \\
& \text { Vent to tip of tail } 70 \mathrm{~mm} \text {. }
\end{aligned}
$$

This is the largest member of the genus and we have specimens nearly a meter in length. It is strictly nocturnal but by no means rare. During the day it may be found hidden in various situations, among rocks, under decaying vegetation, but most often in the rolled up "boots" of the fallen palm fronds —called in Cuba "yaguas." Where groves of Royal Palms stand among mangos or thickly planted bananas so that the ground is well shaded and damp, many of the yaguas when unrolled or better cut into with a machete will be found to contain Majás of this species passing the day closely coiled into almost a sphere. The snakes are extremely sluggish and make absolutely no resistance to capture or handling. That they are voracious, however, is shown by the fact that a large individual once crawled during the night into the junior author's aviary and having devoured a dove found it impossible to repass through the wire of the cage. It remained quietly coiled in a corner causing consternation among the inmates until caught. When surprised or handled this snake discharges a whitish slime from its vent which is extremely offensive, in fact more pungent even than the musky fluid discharged by the various species of Thamnophis or Natrix of North America.

\section{Tropidophis pardalis (Gundlach).}

Plate 5, fig. 2.

\section{Maja.}

Diagnosis: - A small spotted constricting snake, having the habits and general appearance described for $T$. maculata but with the belly-scales less than 160 in number; the body being correspondingly shorter and rather stout.

Description:-Adult M. C. Z. 10,840. Cuba: Havana Province; San Antonio de los Baños, February, 1915. Thomas Barbour.

Head slightly distinct from neck; rostral decidedly broader than deep, 
just visible from above; frontal somewhat longer than broad, distinctly shorter. than its distance from the rostral; parietals short; one pre- and two (rarely three) postoculars; nine (or ten) upper labials, fourth, fifth, and sixth entering orbit; scales smooth in twenty-five (often twenty-three) rows; ventrals 152 (range 140-158), anal entire; subcaudals twenty-nine (range 22-30).

Colour (in life):- Bromnish or grayish above with usually four, sometimes six longitudinal series of dark blotches. When there are six the two middorsal series of spots are largest, when but four rows they are of about equal size. There is sometimes a conspicuous dark spot on the crown and often a cross-bar on the snout, and a dark streak on each side of the head. Very young individuals sometimes present a beautiful semilunar spot of yellowish white on the nape or postparietal region. The belly is yellowish with a double series of alternate or opposite dark markings.

$$
\begin{array}{cr}
\text { Dimensions: - Total length } & 210 \mathrm{~mm} . \\
\text { Vent to tip of tail } & 32 \mathrm{~mm} .
\end{array}
$$

This snake is the smallest and in Cuba at any rate probably the least common member of the genus except semicinctus. Its habits differ in no wise from those of its ally $T$. maculatus. At first sight it appears very similar indeed to this species but it may usually be separated by its darker and duller colouration, with series of much larger dark blotches and it may always be recognized by its having fewer ventral scales. It is distinctly a shorter, stouter snake than the other. It is found in the Bahamas on New Providence, Andros, and Eleuthera. On New Providence it is very common indeed. Here it is called the Thunder Snake for it frequently appears crawling by daylight after heavy thunder showers which doubtless fill its retreats with water and drive it abroad.

\section{Tropidophis MACUlatus (Bibron).}

Plate 5, fig. 3.

\section{Majá.}

Diagnosis: - A rather small spotted constricting snake, sluggish and inoffensive, which is only to be confused with $T$. pardalis and from this species it may be known by having the belly-scales more than 165 in number. This and the others of the genus make no effort to escape but coil up tightly into a sphere when disturbed. 
Description:-Adult M. C. Z. 10,836. Cuba: Pinar del Rio; Guane, February, 1915. Thomas Barbour.

Head not very conspicuously distinct from neck; rostral very slightly broader than deep, just visible from above; frontal wide but longer than broad, distinctly shorter than the distance from rostral, longer than the parietals; one (sometimes two) pre- and three (sometimes two) postoculars; nine (or ten) supralabials, of which the fourth, fifth, and sixth enter the orbit; scales smooth in twenty-five (or 27 or 29) rows; ventrals 189 (range; 170-210) anal entire; subcaudals forty-two (range 25-42).

Colour (in life):- Reddish or bluish gray, with six or eight more or less regular rows of spots, sometimes light edged and usually alternating; the two middorsal series by far the largest; belly chrome-yellow or ochraceous yellow with usually a double series of dark spots which may be definitely alternating or exactly opposite.

$$
\begin{array}{lr}
\text { Dimensions: - Total length } & 320 \mathrm{~mm} . \\
& \text { Vent to tip of tail } \\
& 40 \mathrm{~mm} .
\end{array}
$$

The habits of maculatus are those of the other species of Tropidophis and there seems to be nothing local about its distribution, as it is also found in Jamaica, Haiti, and Navassa Island. In Jamaica it is almost extinct owing to the appetite of the introduced mongoose. In Haiti it is also rare and there is some doubt as to the validity of the form hatiana of Cope based upon Haitian specimens. Its peculiar character was supposed to be due to the presence of an interparietal, and twenty-nine scale-rows. But all Haitian examples do not have interparietal and although we have not observed the scale ever in specimens from elsewhere; the validity of haetiana must therefore remain in doubt until a large series from both Cuba and Haiti can be secured. As to the status of the species upon Navassa we know nothing.

59. Tropidophis semicinctus (Gundlach \& Peters).

Plate 15, fig. 4-6.

$$
\text { Majá. }
$$

Diagnosis: - A rather small, sluggish, inoffensive constrictor with a double series of large conspicuous dark spots, sometimes confluent into cross-bands one on each side of the distinctly compressed body. 
Description:-Adult M. C. Z. 10,822. Cuba: Cienfuegos, Soledad, 1915. R. MI. Grey.

Head rather distinct from neck; rostral a little broader than deep; just visible from above; frontal a little longer than broad, as long as its distance from the rostral; parietals rather small; one pre- and three postoculars; nine upper labials, fourth, and fifth entering the eye; scales smooth, in twenty-five rows; ventrals 205; anal entire; subcaudals forty-six.

Colour (in fresh specimen):- Creamish yellow, a double series of large black spots, one on each side. The spots sometimes confluent. Throat and upper labials yellowish, remainder of head chestnut-brown.

This very distinct and peculiar snake is excessively rare, one of the rarest in Cuba. The only specimen in the M. C. Z. is the one described. It has been taken at Borrero on the Guantanamo River by the junior author who has specimens from Manzanillo and Cuabitas near Santiago; there are also two specimens in the U.S. N. M. We know really nothing of its habits, beyond the fact that it is perfectly inoffensive, simply rolling up into a ball with its head tucked away inside and remaining motionless until disturbed. It is like its close relatives, nocturnal.

Still more recently Mr. W. S. Brooks has found it in the Island of Pines where it was previously unknown, and the M. C. Z. has also received a specimen from Cardenas.

\section{NAtricidae.}

60. Tretanorimus variabilis Duméril \& Bibron.

Plate 15, fig. 9.

Catíbo (Western and Central Cuba); Memíso or Quimbólo (Eastern Cuba).

Diagnosis:-A wholly aquatic snake, grayish olive in colour with many much darker cross-bands. The head depressed and the eyes and nostrils pointing upward as an adaptation to the aquatic habitat.

Description:-Adult M. C. Z. 10,820. Cuba: Pinar del Rio; Guane, Rio Cuyaguateje, Spring of 1915. Thomas Barbour and W. S. Brooks.

Rostral much broader than high, scarcely visible from above; nasals in contact behind the rostral; internasals much longer than broad, the internasal suture but slightly if any longer than the prefrontal suture; frontal very much longer than broad, about as long as prefrontal and internasal sutures together, 
not much more than half the length of the parietals; loreal almost twice as long as high; two pre- and two postoculars; temporals $1+2$; eight upper labials, the fourth only entering the eye; four lower labials in contact with the anterior chin-shields, three with posterior; posterior chin-shields a very little longer than the anterior and separated from each other by four scales; scales keeled in nineteen rows; ventrals 163 , anal divided, subcaudals fifty-seven.

Colour (in life):- Grayish olive above with dark slaty, almost black, cross-bands, the first sending an extension forward to the posterior border of the parietal shields; a dark streak on each side of the head; below bluish gray marbled and flecked with whitish.

This species is remarkably uniform in colouration. A few variations occur among the head scutes, thus the preoculars may be fused into a single scale; five instead of four lower labials may be in contact with the anterior chin-shields. From various sources we find the range of counts to be ventrals 131-167; anal divided; subcaudals 48-81. Boulenger (Cat. snakes, Brit. mus., 1893, 1, p. 282) says:-

"Olive or blackish ahove, witl or without blackish cross-bands; a more or less distinct light lateral streak on the second and third rows of scales; a dark streak on each side of the head, passing through the eve; belly orange or red, dotted or spotted all over with brown or brown dotted with pale."

These remarks are very far from being in accord with our considerable experience of this snake in the field. We have never seen a blackish example, nor one lacking the cross-bands, nor one with red or orange on the belly. Boulenger had but three specimens before him when he wrote the Catalogue and they were probably badly preserved. The white lateral band, he mentioned, is always found in the young, but we have never observed it on adults. In the young also the dark cross-bands appear as oblong or squarish dorsal patches which become extended into the strap-like bands with increasing age.

The Catibo or Quimbólo is wholly aquatic and also strictly nocturnal. By day it may be found hiding beneath stones or in accumulations of drift vegetation, especially in the torrential mountain brooks. In these streams it occurs quite abundantly, as in the more slowly flowing rivers or lagoons and lakes choked with water plants. It is absolutely inoffensive and the largest individuals never open their mouths to bite when caught, nor offer the slightest resistance. In the early morning or at dusk they may sometimes be seen partly emerged from their lair, with their heads near the surface of the water. They appear to breathe at the surface at very long intervals and we have never seen 
one do so during midday, although we have found many specimens under rocks by day, which we would surely have seen long before had they come forth to breathe. By night they move about slowly in the water or lie in wait for their prey, usually cyprinodonts, called in Cuba Guajacones, and then with the aid of a light they may easily be collected. The natives in general have no fear of this snake, and they have frequently told us that they have often felt them swim against their legs while fording a river at night. Nothing whatever is known of their breeding habits. With a single exception they have not been observed on land for even a short time. In April 1917 Mr. W. S. Brooks while digging in a cave in the Sierra de Casas, Island of Pines, caught a very small and young specimen; it was about eight inches long and more pallid in colour than an adult. The cave was half a mile or more from the nearest small stream and possibly had been resorted to for oviposition. Specimens a meter in length are decidedly larger than the average.

The species is very widespread and fairly abundant in the rivers and streams about Guane, especially the Rio Cuyaguateje, in the streams about Pinar del Rio and San Diego de los Baños, in the Lake and Rio Ariguanabo at San Antonio de los Baños, in the streams about Cienfuegos, in the Rio Tana at Manzanillo, and in the waters near Guantanamo. The species is the only one of the genus which occurs in the Antilles, although there are several species on the mainland occurring from Upper Central America to Ecuador.

\section{Alsophis ANGUlifer (Bibron). \\ Plate 15, fig. 7. \\ Jubo; Culebra.}

Diagnosis: - A large, active terrestrial snake, usually slate coloured with black spots. The black spots scattered and usually confined to a single scale.

Description:-Adult M. C. Z. 2,195. Cuba (a cotype Mus. Hist. Nat. Paris).

Rostral much broader than high, barely visible from above; internasal suture about equal to the prefrontal suture; frontal broader anteriorly, narrower posteriorly than the supraoculars, a little longer than its distance from the tip of the snout, shorter than parietal suture; nostril large, between two large nasals; loreal medium, slightly longer than high; one preocular, not in contact with frontal; two postoculars, about equal in size; temporals one plus two; eight supralabials, third, fourth, and fifth in contact with eye; fifth 
and those following it suddenly much larger than the others; five lower labials in contact with anterior chin-shicld which is shorter than the posterior; seventeen rows of smooth scales, with two conspicuous pores near the tip; 169 ventrals; anal divided; 115 pairs of subcaudals.

Colour (in life): - In general steel-gray sometimes greenish, sometimes plum-colour, and sometimes distinctly reddish. Often scattered black spots which appear upon the tail frequently at regular intervals. A dark stripe between the eye.

$$
\begin{array}{ll}
\text { Dimensions: - Total length } & 950 \mathrm{~mm} . \\
& \text { Vent to tip of tail } \\
& 306 \mathrm{~mm} .
\end{array}
$$

The Jubo reaches a very considerable size. Individuals of five feet are by no means rare in the Cienaga de Zapata where the species is very abundant; a female $5^{\prime} 8^{\prime \prime}$ long which contained fifty-eight eggs is in the collection of the junior author. The snake has a curious habit of flattening the neck just posterior to the head and waving the flattened portion about in a threatening manner. This has given rise to a widespread belief among the country people that the species is a very dangerous one, while the more ignorant ones also believe that it lashes its enemies savagely with its tail; the same sort of belief which gave rise to the name coach-whip snake among the negroes of the southern United States. The Jubo is found widespread through the whole Island, but is much more abundant in swampy lowlands and about lakes than in the forests or the limestone Sierras. Specimens from Oriente which we have seen have the scales each with a white dot at the apex and have given rise to the trinomial adspersus (Gundlach \& Peters, Monatsb. Berl. acad., 1864, p. 388). Dr. Stejneger's recent paper shows that all of the examples from Oriente in the U. S. N. M. show this colour-character, so that the race 4 . angulifer adspersus may be considered established. The collection of the junior author substantiates this observation. Generally speaking this is the most common ophidian of Cuba.

\section{Leimadophis andreae (Reinhardt \& Lütkent).}

Plate 15, fig. 8.

Jubito; Magdalena.

Diagnosis: - An active little snake, slender, mostly clear black but with pure white markings scattered variously upon the sides and belly.

Description:- Adult M. C. Z. 10,900. Cuba: Cienaga de Zapata, March, 1915. Thomas Barbour. 
Rostral scarcely visible from above; internasal suture very slightly shorter than prefrontal suture; frontal long and narrow, as long as parietal suture, but slightly shorter than the parietals; loreal almost square; one large pre- and two postoculars; one large and broad anterior temporal, followed by two lesser temporals; eight supralabials, third, fourth, and fifth entering eye; posterior chin-shields much longer than anterior; seales in seventeen rows many with a single rather inconspicuous apical pit; 145 ventrals, anal divided, subcaudals 96 pairs.

Colour (in life):- Black above, usually a white spot on each scale of the lowest lateral row, gastrosteges grayish or white with a black posterior margin; chin and upper lip white; a white line around the canthus from eye to eye, white spots just behind each parietal shield.

$$
\begin{array}{lr}
\text { Dimensions: - Total length } & 501 \mathrm{~mm} . \\
& \text { Vent to tip of tail } \\
& 80 \mathrm{~mm} \text {. }
\end{array}
$$

Specimens of Leimadophis collected in the Island of Pines were much more profusely marked with white than specimens from western Cuba and were named L. nebulatus (Barbour, Ann. Carnegie mus., 1916, 10, p. 305). Since then the junior author has sent to the M. C. Z. similar specimens from Oriente. The fact that all the Island of Pines specimens seem to be peculiarly marked while only those from a distant part of Cuba bear similar markings would suggest that the name nebulatus might for the present, at least, be allowed to stand, and possibly we must recognize a similar race peculiar to Oriente for which the name orientalis would be appropriate (TrPe, M. C. Z. 11,726 from Guantanamo).

Dr. Stejneger's recent paper (loc. cit., p. 285) also concludes that there may be three races in this species. All of his examples except one from Oriente being differently marked from the eastern series.

We may also in this connection discuss the supposed Cuban species Dromicus temporalis Cope. Gundlach says that the species was collected at Monte Verde by Charles Wright and that he had never seen it. Turning to the original description, however (Proc. Acad. nat. sci. Phila., 1860, p. 370), we find that Cope says "Habitat probably Cuba. Mus. Comparative Zoölogy, Cambridge, Mass."; an early and faded label apparently in Cope's handwriting indicates the type as M. C. Z. 297. The type though very poorly preserved really represents, as Boulenger has stated, Urotheca lateristriga Berth. a Central American species. It must therefore be removed from the list of Cuban species. Cope also (loc. cit., p. 371) describes Scolecophis fumiceps with similar data, viz. 
"probably Cuba," and the type supposed to be in the M. C. Z. This specimen cannot be found but from the description is evidently a Tantilla, also doubtless Central American.

To return to Leimadophis andreae we may say that it is a common and widespread lowland species, apparently more abundant in the region of the Cienaga de Zapata than elsewhere. It often burrows underground and is very frequently turned out by the plough. It shows these varied types of colouration and a range of ventral and subcaudal counts, there being about 133-149 ventrals and about 85 to 100 pairs of subcaudals. The individuals common about the Laguna de Manaté, a brackish lagoon near Guantanamo Bay, are larger than those so common about the San Carlos Plantation some miles inland. Here they live under the labourers' houses coming up through the cracks in the floors. In the casa vivienda they were often found living in cracks in the wall close to the floor and even under the brick floors as well (Ramsden).

Key to the Species of Arrhyton.

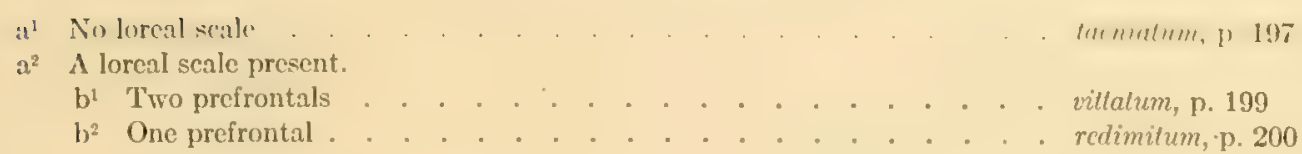

63. Arrhyton taeniatum Günther.

Plate 15, fig. 10, 11.

Culebrita.

Diagnosis: - A small brown snake with two light longitudinal lines above narrowly separated by a brown stripe. Ventral surface yellowish or creamcolour. In old specimens the light dorsal stripes are barely visible. Size larger than the following species, reaching eighteen inches.

Description:- Adult M. C. Z. 10,916. Cuba: Soledad, near Cienfuegos, Spring of 1915. R. M. Grey.

Rostral projecting, much broader than high, distinctly visible from above; internasal suture much shorter than prefrontal suture; frontal one and one third times as long as broad; as long as its distance from tip of the snout which is slightly longer than parietal suture; nostril between two nasals; no loreal; one preocular not touching frontal; two postoculars the upper larger; temporals 
$1+2$; seven upper labials, third and fourth entering the eye; four lower labials in contact with anterior chin shields which are shorter than the posterior; seventeen rows of smooth scales around the body; 180 ventrals, anal divided; 86 subcaudals.

Colour (fresh in alcohol):- Rich mahogany-brown above, two lighter stripes each covering two rows of dorsal scales extending from occiput to tail and separated by the middorsal row which is dark brown like the sides. The whole head and dorsal surface with a beautiful peach-blow iridescence; lower surfaces creamy white. A few light spots and dots on snout and above the eyes.

Dimensions: - Total length Length of tail
$465 \mathrm{~mm}$.

$117.5 \mathrm{~mm}$.

In M. C. Z. 8,507, a half-grown example from near Cojimar, Havana Province, Cuba; spring 1913, T. Barbour collector, the colours are much lighter, the light stripes are three instead of two scales wide and stand at much greater contrast with the brown ground-colour of the back. The snout is rounded and hardly projecting. The projecting rostral, so evidently modified for burrowing, is apparently only acquired by the fully adult individuals. In this immature example there are seventeen rows of scales, 168 ventrals, the anal is divided and there are 89 subcaudals.

The small snakes of this and the following species are perhaps entirely nocturnal. By day they are found turned up from the earth by ploughs or hidden under flat stones. We have never seen one moving abroad and they are entirely unknown to the majority of the Cuban country people. They may be more strictly subterranean than nocturnal although this is not easy to prove, the strongly modified projecting rostral region and the small ill-developed eye with round instead of elliptical pupil suggest this possibility. These snakes are very rare and are but poorly represented in museums. They also appear to vary considerably, as is common with other species of similar habits, - and some variations have given rise to synonymous names ( $c f$. under A. vittatum). Having seen the various specimens collected by the writers and those in the museums of Washington and Havana there seems to be no reason to suppose that this and the following species do not occur widespread throughout Cuba; they have been found in a perfectly haphazard way from San Cristobal in the west to the Guantanamo area in the east. More specimens have been taken about the latter locality by Gundlach, Wright, and the writers than anywhere else; probably because the locality has been more intensively collected. 


\section{Arrhyton vittatum (Gundlach \& Peters).}

Plate 15, fig. 12, 13.

\section{Culebrita.}

Diagnosis: - A small burrowing snake red above and white below with two dark lateral stripes and generally a darker dorsal brown band. Size less than the preceding species, usually about ten inches.

Description:- Adult M. C. Z. 10,846. Cuba: 10 miles S. W. of Aguada de Pasajeros, near Rio Hanabana, Spring of 1915. Thomas Barbour.

Rostral much broader than high, barely visible from above; internasal suture far shorter than prefrontal suture; frontal one and one third as long as broad, as long as its distance from the tip of snout which is about the same as the parietal suture; nostril small, pierced in a single nasal; loreal moderate, rectangular, longer than high; one small preocular, two postoculars the upper the larger; temporals $1+2$; seven upper labials, third and fourth entering eye; four lower labials in contact with the anterior chin-shields; seventeen rows of smooth scales around the body; 123 ventrals, anal divided, seventy-one subcaudals.

Colour (in life):- Bright brick-red, a dark brown band from the middle of the third to the upper third of the fourth rows of scales; no evidence of a median middorsal stripe. Lower surfaces cream-yellow.

$$
\begin{array}{cr}
\text { Dimensions: - Total length } & 244 \mathrm{~mm} \text {. } \\
\text { Length of tail } & 82.2 \mathrm{~mm} .
\end{array}
$$

M. C. Z., 7,925 from near Cienfuegos, 1910, R. M. Grey collector, is the same as the specimen described in colour except that it has faded slightly and has a distinct middorsal stripe. Its scale counts are 115 ventrals, anal divided, fifty-three subcaudals.

M. C. Z., 7,952 from near the Rio Anallo, Cuba, collected by Barnum Brown and received in exchange from Amer. Mus. Nat. Hist., 1910, is exactly similar to the preceding in colour and counts 122 ventrals, anal divided, sixty subcaudals.

We cannot see that this species differs from the preceding in habits or distribution. We have seen no specimens nearly as large, nor none in which the rostral region is modified as in the specimen of $A$. taeniatum described or 
in Cope's type of the synonymous A. fulvum in the U.S. N. M. We should say that this species seems to be a little more abundant than $A$. taeniatum but it also is rare and entirely unknown to most native Cubans.

\section{ARrhyton Redimtum (Cope).}

Diagnosis:- A small longitudinally striped burrowing snake, having very few ventral scales (about 141) and but one loreal and one prefrontal.

Description: - (After Cope). One preocular, one loreal, one nasal. Rostral plate small, obtuse. Dorsal scales smooth, poreless, in seventeen rows. Tail elongate. Inferior labials, nine. Fide Bocourt ventrals 141, caudals 120 .

Colour:- (After Cope). Brownish gray, lighter beneath. A narrow dark line along the fourth row of scales. Another line upon the vertebral series. Two light occipital spots.

We know nothing of this species, which Stejneger (loc. cit., p. 287) concludes to be valid. We had believed that it was a synonym of $A$. vittatum until we read Stejneger's account $(q . v$.$) . Only two specimens have been recorded, one, the$ type (lost) but partially described by Cope, and a second by Bocourt.

It is either not Cuban at all or else excessively rare, while the possibility that the records are based upon anomalous specimens is by no means excluded, indeed rendered more probable, for in 1918 three additional examples of $A$. taeniatum were found at Soledad near Cienfuegos (Barbour) and one A. vittatum was taken near Cojimar (Señor Fermin Cervera).

\section{REPTILIA: TESTUDINATA.}

\section{Testudinidae.}

66. Pseudemys palustris (Gmelin).

Plate 15, fig. 14-16.

Jicotea; Jarico $\left(\sigma^{7}\right)$.

\section{Description:-}

"Adult fomale; U. S. N. M. No. 25642; San Juan; [Porto Rico] January 14, 1899. Shell moderately convex, the height being more than one-half the greatest width; length of carapace less than two and a half times the height of the shell and about one and one-third times its greatest width; carapace faintly keeled and with longitudinal wrinkles crossed by radiating ridges, which are especially strong on the anterior costals; nuchal narrow; first vertebral shield urceolate, anterior and posterior sutures of same length; lateral sutures of second, 
third, and fourth vertebrals much longer than the anterior and posterior sutures; vertebrals much narrower than costals; posterior margin of carapace slightly serrate, each of four posterior marginals on each side being faintly emarginate; carapace broader behind than in front, the posterior marginals flaring out considerably; plastron less than two thirds and more than one-half the greatest width of the carapace; the posterior lobe a trifle wider than the anterior, its length much less than the width of the bridge; abdominal suture longest, equaling those of the pectorals and femorals together; humeral suture shortest; gulars projecting, cut off squarely anteriorly; plastron slightly emarginate behind; axillars and inguinals large, latter largest; head moderate; snout short, pointed, feebly projecting; upper jaw with a very slight median noteh, no cusps; jaws feebly denticulated; alveolar surface broad, with a deep notch behind on the median line; symphysis of mandible as broad as one-half the longest diameter of the orbit; digits connected with broad webs. Color (in alcohol) of carapace above nearly uniform tawny olive; plastron yellowish, with obscure dusky symmetrical sinuous markings all over; top of head without markings; yellowish lines narrowly edged with blackish on sides and under surface of head and neck, one from the nostrils crossing the upper jaw obliquely and ending abruptly at the posterior angle to the mandible, another from above the nostrils, crossing the eye to the lower posterior edge of the orbit, and thence obliquely down and backward to the corner of the mouth, continuing backward under the tympanum down the side of the neck; two fainter lines, one between the two just described and one above the transocular line, crossing the tympanum; a line on the symplysis of the mandible bifurcating on the chin and a third median line originating on the chin a short distance behind the fork, the three continuing parallel down the under side of the neck; two similar but wider lines on the upper side of the fore legs and two on the under side of the hind legs." Stejneger, Ann. rept. U. S. N. M. for 1902, 1904, p. 711-713.

In spite of popular belief there is but one species of Jicotea found in Cuba, which is also found in Jamaica, Haiti, Porto Rico, and the Island of Pines. So far no separation has been made of individuals from these several localities, although it is by no means improbable that in the future it may be determined that valid, recognizable races occur upon each island.

The Jicotea is found in suitable situations all over the Island. In the larger rivers such as the Rio Cauto it is abundant although it is constantly diminishing in numbers since many individuals are killed and eaten. In western Cuba large numbers may be seen in Lake Ariguanabo and in the river into which it empties only to disappear in a limestone cavern within the town of San Antonio de los Baños. The Jicoteas are sensitive to the least cool weather and are only seen at their best when basking in the torrid rays of a vertical sun. Their flesh is delicious, and if measures for their preservation are not taken it is probable that the march of time will see them exterminated. The species is already far from common in Porto Rico and Jamaica.

In the market place at Guantanamo they bring from ${ }^{\circ} .40-{ }^{\circ} .60$ each. They are often caught by submerging a deep pouch of chicken wire held open by an iron ring. This hangs from a pulley operated from some overhanging limb. 
A piece of meat is hung about the net for bait and while the turtles are tugging at the meat the whole affair is hoisted and they are caught. They are then kept in a stockade or pen in shallow water and fed upon table-scraps until needed. They are also often caught by sinking a barrel until its rim is only about six inches above water. A plank is laid across the barrel's open end and slanting boards make this a convenient place to "take the sun" as the Cubans say. But when evening comes they dive from the cross-boards into the barrel, whence they cannot escape.

\section{REPTILIA: LORICATA.}

Crocodylidae.

Key to the species of Crocodylus.

$a^{1}$ Four nuchal scales, no longitudinal ridge in front of eye . . . . . . . acutus, p. 202

$a^{2} \quad$ Six or eight large nuchal scales, an obtuse ridge in front of each eye . . . . . rhombifer, p. 203

\section{Crocodylus acutus Cuvier.}

Plate 12, fig. 1.

\section{Caiman.}

Diagnosis:- A crocodile having four nuchal scales forming a square, a more or less distinct median ridge or swelling along the middle of the snout and no longitudinal ridge in point of the eye. Colour rather light olive, yellowish beneath.

Description: - This creature is so widely known that a detailed description would be quite superfluous. The diagnosis given above serves to distinguish this species from $C$. rhombifer the only other with which it might be confused.

The remarks quoted from Gundlach and added under C. rhombifer include much information regarding this species, as well. While $C$. rhombifer is essentially Cuban, $C$. acutus is very widely distributed. It is still found sparingly in some of the Keys and about Cape Sable in Florida although it has probably been quite exterminated in Biscayne Bay, whence Jeffries. Wyman recorded it in 1870. It is rare but still to be found in both Haiti and Jamaica, while about the estuaries and saline lagoons of the coasts of Honduras and Nicaragua it is excessively abundant. In general its range in Central America may be said to extend from the coasts of Vera Cruz at least to Darien and on the Pacific coast it occurs from western Mexico to Ecuador. 
In Cuba it is still widely distributed but, of course, gradually becoming rarer. It occurs in ponds in the mangrove swamps, in estuaries and about river mouths always associated with salt or brackish water. Many were observed in the Estero de Juan Hernandez west of Palo Alto on the south coast of the Province of Camaguey, in 1915; but none were seen or heard in 1917 about the shores of the Ensenada de Cochinos (Barbour). Here C. rhombifer comes to salt water and the local belief is without doubt true that the two species are never found in the same localities. This erocodile was formerly common about the mouth of the Guantanamo River and the smaller streams which enter that bay, but like so many of the larger water birds they are, since the establishment of the Naval Station, very rare as they afford a too tempting a target to the more or less irresponsible "sportsmen."

68. Crocodyuds rhombifer Cuvier.

Plate 12, fig. 2.

\section{Cocodrilo.}

Diagnosis: - A crocodile having six or eight large nuchal scales, and with a more or less marked obtuse ridge in front of each eye. Colour very dark olive everywhere flecked and vermiculated with yellow. These spots most abundant upon the sides and limbs.

Description: - While this crocodile is peculiar to Cuba and the Island of Pines and now rare and restricted in its distribution the diagnosis given above will serve to separate it at once from its only congener in Cuba. For this reason and since it cannot be confounded with any other creature a detailed description is quite uncalled for.

Curiously enough there has existed in the literature on these two animals a persistent error regarding their lay names. Thus Humboldt began by calling rhombifer the "Caiman." His error was repeated, so Gundlach tells us, by Pichardo in the first editions of his "Diccionario de Voces Cubanas" and the same mistake was later made by Cocteau in Ramon de la Sagra's History. Gundlach corrected this error in his Erpetologia Cubana, in 1880, and published as well a long and really absorbing account of his observations upon the two Cuban crocodiles during his many years of opportunity to know them. During the last few years the senior author has made three visits to the Cienaga de Zapata and a few of his notes on the present status of C. rhombifer conclude the remarks upon the species. 
A free translation of Gundlach's fascinating and simple Spanish style follows:-

"I have kept in the same tank for many years two Cocodrilos and one Caiman, and thus I have been able to observe them constantly. The Cocodrilo walked with its legs in such a position as to carry its abdomen lifted from the ground, while the Caiman walked with its abdomen against the ground. This gives more agility to the Cocodrilo, and also makes it appear higher than the other. Humboldt says referning to the Cocodrilo "that it was very daring." This I have also been able to confirm by observations. My specimen of the Caiman was a larger animal than either of the two Cocodrilos, but even so it would run away from them when I fed them, making it necessary that I feed first the Cocodrilos and when these were satisfied, the Caiman. If the Caiman was in the water it would at once leave it upon the entrance of either of the Cocodrilos. Humboldt also says "they never mix with each other." This I have also found to be true from my experience in the Cienaga de Zapata which is inhabited by hundreds of Cocodrilos, and there is not a single Caiman to be seen. I have been assured that the same conditions exist in the Isla de Piños. The Cocodrilo lives in fresh waters, the Caiman in mixed or brackish waters at the mouth of streams, as also in nearby lagoons even if these are of fresh water. There are many places on the coast of the Island of Cuba, which are known as "Caimaneras" by reason of the abundance of Caimanes. Of these I mention the two best known, which I have personally visited, one in Cienfuegos harbour, and the other in the harbour of Guantanamo. While I am making comparisons of the two species, I shall indicate the principal difference between them as to the length of the snout; it cannot be determined unless one has the two species together for comparison. The difference that may best be noted when one has but one species, or a part of the body only are: the Cocodrilo has six perfect rows of keeled scales, while the Caiman has but four perfect rows, the other two being imperfect and scattered. The eye of the Cocodrilo is dark olivaceous, while that of the Caiman is light greenish. The colour of the body of the Cocodrilo is variegated yellow on a dark background, while that of the Caiman is uniform ashy green.

"One may read most interesting accounts of this group of Cuban animals in la Sagra, but with all I must correct some of those data. On the bottom of page 40 he says "We feel we have reason to indicate that the species known in that country (Cuba) by the name of Cocodrilo $(C$. acutus) rarely grows to the size of the other species, Caiman, which reaches a length of from six to seven feet, but we cannot explain the reason for this \&c. \&c.' In the first place one must invert the names in the above quotation, as I have already said that the Cocodrilo is the Crocodilus rhombifer, while the Caiman is the $C$. acutus; in the second place, it is quite impossible to know which of the two reaches the greatest length, as this depends on the age of the individual who continues growing in size throughout his whole life; and in the third place they may reach three times the length indicated by Cocteau. I have seen, (and in fact have its skull), a Cocodrilo ( $C$. rhombifer) whose length was sixteen and one half feet, and a Caiman (C.acutus) eighteen feet in length. Neither of these are, I am sure, the largest that grow.

"Again Cocteau says: 'Both these Crocodiles live in the same places, but always fighting each other.' I have already said that they do not live in the same localities. Some may call my attention to the fact that there have been Caimans taken from the river Hatiguanico which drains the Cienaga de Zapata, the latter being full of Cocodrilos; to these I shall answer that this river is brackish near its mouth, where it enters Broa bay.

"On page 50 of the same work one may read an observation of la Sagra's that a five foot individual kept at the Botanical Gardens at Havana in a corral made of stout stakes driven 
into the ground to a depth of two feet dug subterranean galleries by which it escaped. I have nothing to say against this, (as I have been assured that the Caiman digs caves in which they hide), though I myself have only seen the Caiman casually upon my travels. However it is stated at the end of the article in question that this individual was a $C$. rhombifer later presented to the Museum of Natural History at Paris. My observations show that the two Cocodrilos kept at my home never dug out the shallowest cavities, neither have the inhabitants of the Cienaga ever seen any of their dens. 'The Crocodrilos of the Cienaga de Zapata retire as the waters recede or dry up, to the nearby lakes, or to the deeper holes of the swamp itself. The females leave the water for egg laying, digging a hole or trench in the shore close to the water; all the eggs are laid at one time, and are covered by the dirt taken out of the trench. I have been unable to find out the time one takes to deposit her eggs, as also the time of incubation, but I do know that it takes some weeks. Mr. Francisco Sauvalle gave me a set containing sixty eggs, (I do not know what the maximum number may be) of the Caiman. After a long time I tried to empty some of these eggs for my collection; upon opening one of them I heard sounds from within, and when I had fully opened it I took out of it an embryo, which was to all appearances ready to emerge. I firmly believed this, as it tried to bite me, but upon a closer examination found that it still had a small sac of yolk attached to its abdomen at the umbilicus. I withdrew from the egigs other embryos to be put into alcohol. One morning two weeks later, the remaining eggs were cracked and the embryos had all been hatched at the same time. 'These differed from the ones I had taken out, only in that these did not have the yolk attached as had the others. Two of the eggs being larger than the rest I suspected that they might contain twins. 'I was anxious to learn whether these were malformed or stuck together, or whether they were normal, so I opened them, very carefully, longitudinally so that I might be able to keep the shells; finding within the two embryos quite normal and separated from each other.

"'The eggs measured $73 \times 47$ millimeters or $81 \times 42$ millineters, while the double eggs measured $100 \times 50$ millimeters. Both extremities were alike, the color of the egg being vitreous white, not unlike crockery, and very hard. The Cocodrilo egg of my collection measures $78 \times 52$ millimeters. The young Caimans grow very slowly but quicker than the adults or the half-grown. I have no notes as to their growth, but I have reared an alligator from the Mississippi which I received in 1868, when newly hatehed, from my friend Pocy. I carried him home in an empty cigar box (the 100 cigar size), and after four years he had only grown to a length of thirty inches. This animal was very tame, leaving the water, upon a signal given by me, to receive its food which consisted in fowl entrails and bits of beef. Its tameness made it a great pet, which at the same time was the cause of its undoing, as it was stolen from me.

"Both of the Cuban species will leave the water, climbing upon a log or stone or remaining upon the ground, but take quickly to the water upon the approach of man. After a little while they may come up some distance away, never showing but just the top of their heads, that is to say, only that part from the nasal openings to the back of the two elevations on each side produced by the prolonging backward of the postorbital crest. The eyes remain above the surface of the water. As one approaches, the visible portion disappears under water, the course of the animal being easily seen by the ripples on the surface. I have never seen individuals over two and one half to three Spanish yards in length in the parts of the Cienaga where I have hunted them, but in an interior lagoon known as "Lil Tesoro" there are individuals six varas in length and perhaps longer. The Cocodrilo sisteen and a half feet long whose skull I have, was killed in that lagoon.

"Another notable difference between the two species is the strong musky odor of the Caiman. Whenever I angered a Caiman it would swell up, at the same time a cone-shaped 
body, denoting the position of the gland that disseminated a strong odor of musk, could be seen on each side of the throat. I have not seen this gland in my tame Cocodrilos, nor in any of the many that I have shot in the Cienaga de Zapata. I cannot be sure that the gland does not exist, but I do assert that it is not visible externally, and that this species does not crude the musky odor.

"The popular saying is that the Cocodrilo, and perhaps the Caiman, will cry like a child in order to attract attention. I have heard them produce a sound but once, this was like the hoarse bellowing of a bull, and was produced by the of of my pair. I am led to believe that this sound is made only at mating time. This sound may probably be heard often in the "Laguna del Tesoro." I once saw the penis of the male in erection, its color was carmine.

"Another belief is that these animals open their mouths so that it may become filled with flies, then it is shut and the flies are swallowed. I have noticed however that they open their mouths when basking in the sun, whether there are flies present or not, and as they have no tongue they could not swallow such small objects. It is my belief that they shut their mouths, because of the tickling caused by the flies, doing so with a noise like a hand-clap.

"They will swallow at once a small animal or piece of beef, but if it be a large one, they will hold it, shaking it the while until perhaps a part may be shaken off. This they will swallow, then continue the process. Another method is to allow the object to rot when it may be the more easily shaken to pieces. These animals do not chew, nor can they cut their food into bits with their teeth. These are used for holding their prey, as also for tearing which is accomplished by a twisting motion such as is used in pulling a nail with pincers. I have often noticed that when I fed large pieces of beef to my Cocodrilos, if a part of it remained outside the mouth, the other Cocodrilo would seize it and by twisting his body rapidly round and round would pry the morsel from the owner's mouth. I should also mention that if the prey was a large animal it would be drawn under, and thus killed; this happens with a pig or dog. It is known that they have killed human beings. I shall recite an episode told me by Don Helvecio Lanier. Once while this gentleman was on the Isla de Piños at Nueva Gerona, one of the numerous prisoners of war interned there insisted upon bathing in a river which was known to be inhabited by a large Caiman. No sooner had he jumped in than he was seized by the beast and pulled under; his companions being infuriated laid traps and caught the animal, which they would have torn to pieces had not Sr. Lanier intervened asking them to allow him to remove the hide, after which they tore the body into bits. Nine foot Cocodrilos or Caimanes are not to be feared, I myself have gone into lagoons up to my chest where they abound, and instead of attacking they have always run away.

"I have found it easier to kill them with shot, even if this be of medium size, than with ball, ${ }^{1}$ the latter must strike at right angles to the skin, else it will rebound upon striking the hard outside integument, the soft under parts being below water. By using biud shot, aiming between the eyes, the shot spreading, some of them will enter through the orbits and perhaps reach the brain. Upon being shot the Cocodrilo will roll about for a few minutes, after which it will become so tired that it will allow itself to be taken by the end of the tail and dragged ashore, there to be dispatched with very little resistance. The Cocodrilo while bcing dragged will not turn against its tormentor, but will do its utmost to pull itself away. One must take care however not to stop once the dragging process is begun so as not to allow the beast a chance to defend itself. I have killed all the Cocodrilos I have shot at. In capturing a Cocodrilo with a lasso, one must be careful always to keep the rope in a straight line away from its long axis, as if it happens to get at light angles, the animal will roll over and over, very quickly winding up the rope about its body and finally reaching its captor's hands, when there is danger of being bitten. If the animal is left tied for any length of time

' It must be recalled that Gundlach had only very antiquated fire-arms. 
it may untwist the rope. This happened to me on one occasion when I left one tied to a tree whose branches were above the surface of the water of a lagoon. Upon returning a few days later I found the rope untwisted and the captive gone. Another method of killing the Cocodrilo is used by the hunters of the Cienaga de Zapata. The animal is approached stealthily by the hunter with a machete in his right hand and his hat in the other, the latter is moved slightly and upon being noticed is attacked by the Cocodrilo. At the rush the man deftly cuts through the beast's neck with his machete severing the spinal column which disables him. Care must be taken not to get within reach of the blows of the Cocorlrilo's tail, as it is well known that mutilated reptiles live for a long time, weeks, and sometimes for months. I had an example of this in my room, where I had killed for momting a Cocodrilo brought from the Cienaga. I quickly skinned him leaving the hearl attached to the skin, and while cleaning it I touched a nerve and the mandibles at once contracted, while I still had both-my arms in the beast's mouth; it became necessary to place a stick between the jaws to keep them open. 'To catch them with a lasso, one must tie within the noose and to it. a piece of meat that will float, as for instance a lung or a dead bird; the Cocodrilo upon seizing it will shake it, thus tightening the noose about its upper jaw. It is better that the noose be made of untwisted strands of Majagua bark which will enter the better between the teeth and not slip.

"Still another way of taking him is when he comes ashore at an accustomed place; a strong pole or light sapling is firmly placed upright in the ground, a noose is attached to the upper end of it, it is then bent over, the noose being held close to the ground by a trigger, which upon being stepped on by the Cocodrilo springs the trap lifting the victim into the air, hanging him.

"The fat of both species is used as a remedy for certain diseases of horses; while those parts of the hide which are free from the larger scales are used in the manufacture of footwear; the penis of the male after being crushed into powder is used in curing lockjaw, and is supposed to have antispasmodic virtues. The eye-tecth (canine-teeth) after being adorned with gold or silver are used as punk-holders for the flint fire-lighting apparatus. To the smaller teeth has been attributed virtue in facilitating teething, when they are made into a necklace and hung about a child's neck.

"I should also mention that these animals will live for a long time without food or drink as I am personally sure of this from the following experience. I received at the beginning of February a small Cocodrilo about two-thirds of a yard in length from my friend Poey; the specimen was tied to a board with its mouth closed. I was afraid to place it in the same pen where I had my large Cocodrilo lest the larger should do harm to the smaller creature, so I left the animal as I received it, without food, drink, or bathing, till the middle of July of the same year, when I finally was forced to place it in the yard with the large one, as I had been unable to construet a separate pen. He seemed to be none the worse for his long fast, showing no sign of weakness. In this case the larger animal did no harm to the new arrival, but on another occasion a small Cocodrilo was swallowed, head first, by the larger one.

"The labourers of the Cienaga cut off the tail of the young Cocodrilos for food. I was anxious to try this morsel, and did so with my friend Mr. Clias. Wright. It was cooked as if it were lobster and was very savoury indeed; I should imagine that an adult would be unfit to eat, as also the Caiman, which has a strong musky odor. Poey on page 106, vol. 2 of his Repertorio, adds a note to my "Revista y Catalogo de los Reptiles Cubanos" saying that he had tasted the tail "finding in it a strong disagreeable musky taste." Perhaps my friend was given the tail of the Caiman instead of that of the Cocodrilo.

"There is a general belief that a Cocodrilo cannot capture a person or an animal if the 
pursued keep zigzaging and making sharp turns, as it is supposed that the reptile cannot turn quickly. This, however, is a mistake as with but a single movement it can turn in a semieircle with its head pointing in the direction where the tail was, and vice versa. What is true is, that they cannot reach up very high, nor can the head be twisted unless the whole body be turned at the same time. The pen in which I kept my specimens was surrounded by a four foot wall, which the larger six and eight foot specimens could not scale. I have said that they could not twist the head by itself, but they can twist head and body very rapidly. When I touch one of them on the side with a stick, instead of his moving away, he will turn in the direction of the stick.

"In swimming, the tail is used with a sculling movement and not the legs. In catching their prey they will mark the place, submerge, swim in that direction, and rise at the precise spot. The hunters knowing this will step to one side and as the animal appears, deal a blow with the machete or else use the ruse with their hat as I have explained above."

At the present time rhombifer is still abundant in the Zapata swamp, although large individuals are very seldom seen. Of six or seven individuals shot none was over seven feet long (Barbour). A mutilated skin, however, in 1913 in the possession of Dr. Campos at the town of Aguada de Pasajeros measured nearly twelve feet in length. Individuals far larger are still reported from the inaccessible interior of the swamp. While riding on horseback or wading through the "tembladera," or ooze, crocodiles are often encountered. The inner marshes of the Cienaga in general consist of an enormous deposit of silt, partially held in suspension in water and resting on a firm limestone substratum. In some localities one meets with muddy lakes or the cloggedup course of some sluggish stream like the lower Rio Hanabana but generally the ooze is sufficiently compacted to support a sort of half floating vegetation of rushes and reeds and in certain areas the great curled-up lily pads which in the Florida Everglades are called "bonnets" are found abundantly. It is among these only that one meets the little yellow rail (Porzana flaviventris) and here generally the crocodiles as well. Lying almost submerged and quite hidden among the "bonnets" they remain motionless until one approaches. Then they sink down and stay quiet or move slowly away through the layer or zone of comparatively liquid mud below the matted roots of the superficial plants. For this reason it is by no means uncommon for the collector or his horse to touch a crocodile so hidden and one that had sunk so quietly that his presence was quite unsuspected. When touched the creature with a sudden squirm thrusts his head clear of the surface apparently to see what has happened and then at a range of but a couple of feet the beast may be killed with almost any sort of fire arms. The senior author met several crocodiles in this way and killed them with a twenty gauge shot gun and bird shot.

It is worth mentioning that Boulenger and others have always spoken of 
this crocodile as a small species. It will be observed from what Gundlach records that this is far from being the case. We have not been able to hear of the occurrence of such large individuals in the Cienaga of the Island of Pines. Here the species is said still to occur quite abundantly, although perforce it is restricted to a smaller area than that occupied by the colony of Cuban individuals. The skull of Gundlach's great example which he mentions is now in the Museo Gundlach of the Havana Instituto de Segunda Enseñanza. It is in a tight case and can not be measured but appears fully two feet long.

We believe that Crocodilus moreleti A. Dumeril from "Lac Flores, Yucatan" was really based upon a Cuban specimen of rhombifer carried to Central America and sent from there to Europe by Morelet who collected it during a visit to Cuba en route. Prof. de la Torre tells us that various molluses were named which had this same history. The Alligator lacordairei of P. de Borre (Bull. Acad. roy. Belg. 1869 , ser. 2,28, p. 110 , plate - ) is we believe based upon a young Crocodilus acutus from Belize, although Boulenger places the name in the synonymy of $C$. moreleti, a species which he recognizes as valid. Dr. Boulenger, of course, did not know of the status of other species collected by Morelet.

Since the preceding account was completed several observations of interest have been made.

During the winter or rather Cuban early spring (February and March) of 1917 the senior author stayed, together with Messrs. John B. Henderson, W. S. Brooks, and the late Goodwin Warner, with Mrr. Walter Wilcox at his large mahogany cutting on the eastern shore of the Ensenada de Cochinos, one of the most inaccessible regions in the Island. Here we found peculiar conditions. On the east side of the Bay the "seborucal" formation comes to the coast, heavily forested. It is a hard tiresome journey over the "diente perro," the curiously eroded limestone, back from the salt water to the great reed-beds and fresh-water pond of the true Cienaga de Zapata system. There are a few bridle paths but moving about is painfully difficult. Numerous fresh streams flow from the Cienaga to the Ensenada, partly under the limestone which often sounds hollow under one's horse's feet, and partially open to the air where the tunnel roof has been dissolved away or has fallen in. Here as in the reed-bed ponds rhombifer abounds. Crocodiles are abundant, and we often saw rather large individuals; one seen on several occasions was probably over eleven feet long. On the opposite shore, the western, the conditions were very different. We frequently hunted along this coast and tramped far inland with Wilcox as guide; he had previously prepared the chart of the Bay since published by 
the American Hydrographic Office. The west shore is a dreary waste, low, sandy, and insect-ridden. The long white beach with its scrubby zone, behind tide-reach, of spindly palms, beach grape, and Ipomoea was broken by an occasional estero or salt-water inlet, muddy and fringed with a true forest of giant mangroves. Inland were mile-long stretches of baked clay, dazzling white and sizzling under a burning sun. These vast level stretches fill up during the summer rains, el tiempo de las aguas, as the Cubans say, and then evaporate and dry and crack during the rest of the year. Near the south coast the heavy winds blow salt water up into some of the flat pans, and a more or less haphazard harvesting of salt is carried on. The whole region should be a typical home for Crocodylus acutus but it is not; C. rhombifer is abundant, in spite of Gundlach, even in the very shore mangroves themselves. We not only never even saw an acutus but the natives all knew of the curious fact of its absence. Evidently the habits which Gundlach noted in captivity obtain under wild conditions and the common acutus, so widespread and at first sight apparently a distinctly dominant type seems unable to compete with rhombifer.

The question least easy to answer is why should not rhombifer be extending its range instead of the reverse. It is probably really a fresh-water loving form which has only adapted itself to life in salt water at this one locality and it is possible that this test or trial is but a transitory one or a recent manoeuvre: De la Torre has often told us of the abundance of crocodile remains in the Casimba de Jatibonico and in the deposits of fossils at the Baños de Ciego Montero. Photographs of a fossil skull, due to the kindness of Dr. W. D. Matthew, show that these early crocodiles are identical with the existing rhombifer. Dr. Matthew kindly allows me to mention this fact here. The sloth bones recovered by de la Torre and the American Museum party under Mr. Barnum Brown were often pitted with crocodile tooth marks. Evidently when these deposits were laid down the Cienaga condition was widespread over the central portion of Cuba and the unwary sloth was dragged to this death by the formerly widespread $C$. rhombifer. Either the crocodiles dragged their prey into the pockets, then submerged, which have now emerged into accessibility or with the rising of the land the bones accumulated into the natural receptacles by washing; this is very unlikely and the abundant associated crocodile bones argue for the previous suggestion. Naturalists await with impatience the appearance of the report by de la Torre and Natthew upon these extraordinary finds. 


\section{POSTSCRIP'T.}

During 1917-1918 the senior author spent fourteen months in Cuba and made several interesting discoveries. A series of what had been called Sphaerodactylus picturatus secured in the Sierra de San. Juan de los Perros shows that that species should not be named as Cuban, and for these individuals the name scaber has been given where previously picturatus was discussed in this work. Another new Sphaerodactylus is described herewith and a note on the Cuban Natrix also now rediscovered is added.

69. Sphaerodactylus intermedius, sp. nov.

Diagnosis: - A medium sized but slender Sphaerodactylus intermediate in appearance between torrei which is stout bodied, and elegans which is even more slender and smaller. Dorsal scales finely granular and neck marked with four dark bands, between these a median gray and two outer white bands.

Description:- Type. Adult M. C. Z. 12,305. Cuba: Matanzas Province; the Sierra de Hato Nuevo between Hato Nuevo (or Martí) and Sabanilla de la Palma, February, 1918. Thomas Barbour.

Snout rather long, not sharply pointed but decidedly acute; the distance from the tip of snout to the eye being slightly greater than that from eye to ear; rostral large with a long median cleft behind; nostril between rostral, first labial, two or three small postnasals and a large supranasal which is separated from its fellow on the opposite side by two scales; four large and one small supralabial to below the centre of the eye; a very feebly developed spine on the upper eyelid; head above and sides covered with fine granular scales enlarged upon the snout; scales of back round, juxtaposed, granular; mental large, two postmentals; one very large, one medium and two small infralabials to below centre of eye; scales of chin and anterior chest region very small, flat, nonimbricating; belly-scales larger, round, flat, imbricating; no regular series of enlarged seales under the rather slender tail.

Colour (fresh specimens):- Body uniform brown, tail brown at base fading into dirty yellow distally, tip pure white. A whitish horse-shoe mark from eye to eye around the occiput followed by a pair of black bands separated by a dirty white area; then a duskier zone followed by another similar pair of dark bands separated by a lighter region. A very faint suggestion of another 
pair of dark bands on the humeral region but the body uniform in colouration.

- Two identical specimens of this lizard were found the same day near Hato Nuevo but no others were observed. Then first caught and brought to Havana we concluded that there could be no doubt but that these two individuals were really very different from both torrei and elegans. Subsequent comparison has but strengthened this and these three species seen in life are vastly more different in appearance than a comparison of the descriptions shows. A fact which is very frequently the case in this very confusing genus.

\section{NATRIX COMPRESSICAUdA (Kennicott).}

Memiso, or 'Miso.

In March 1918 at the Punta de Judas near the boundary of Camaguey and on the north coast of the Province of Santa Clara the first Natrix to have been seen in Cuba in many years was found (Barbour). The snake about ten inches long was found creeping over a narrow mud flat wet with salt water and between tide marks in a region of extensive mangrove swamps. This specimen has been compared with the greatest care with the description of Tropidonotus cubanus Gundlach (Monatsber. Berl. acad., 1861, p. 1001), and both Dr. Stejneger and ourselves have concluded that the example from Punta de Judas agrees well with Gundlach's description. The description, by the way, having recited a scale count within the limits of variation known in Tretanorhinus variabitis both Dr. Boulenger (Cat. snakes Brit. mus., 1893, 1, p. 282) and the senior author has previously been misled into considering cubana a synonym of this species. A careful comparison of the specimen from Punta de Judas with the large series of $N$. compressicauda in the M. C. Z. shows the identity of the Cuban with Floridian examples, and the Cuban snake (scales $21 \frac{135}{71}$ ) is in practically all respects identical with M. C. Z. 7,786 from Key West. A dark brown almost black snake with faint rather zigzag cross-band visible when the light is favourable. This discovery reëstablishes Natrix as a West Indian genus and relegates the species cubana to the synonymy of compressicauda. The habit of living in mangrove swamps and in salt water makes this distribution less remarkable than it would otherwise appear, although it is very noteworthy that the species has crossed the swift Gulf Stream in its migration and that if it has been long established in Cuba that no characteristic variation through isolation has taken place. It must be a recent arrival in Cuba. 
Gundlach remarks that he has found the species in streams near Cardenas living in just the same way as Trelanorhinus variabilis, but he makes no mention of its inhabiting the mangrove areas. In Cuba, where there is but one streaminhabiting snake, this form may easily have invaded the fresh waters from which it is probably excluded in Florida by the abundance of competing types. The junior author has seen a black "memíso" at Guantanamo which may have been this species.

Cope's $N$. anoscopus (Proc. Acad. nat. sci. Phila., 1861, p. 299) has never been rediscovered in Cuba and from the description we believe that Cope had an African species, $N$. fero (Günther) before him. (Cf. Mem. Soc. Cubana hist. nat., 1916, 2, p. 127). 


\section{EXPLANATION OF THE PLATES.}


PLATE 1. 


\section{PLATE 1.}

Fig. 1. Hyla septentrionalis Boulenger. Nat. size.

M. C. Z. 2,655. Havana, Cuba. Thomas Barbour.

Fig. 2. Bufo ramsdeni Barbour. $2 \times$ nat. size.

M. C. Z. 3,212 Type. Los Hondones, Monte Libano, Guantanamo, Cuba. C. T. Ramsden.

Fig. 3. Bufo empusus (Cope). Nat. size.

M. C. Z. 4,169. McKinley, Island of Pines. W. S. Brooks and Goodwin Warner.

Fig. 4. Phyllobates limbatus Cope. $3 \times$ nat. size.

M. C. Z. 7,843. Guabairo near Cienfuegos, Cuba. Rosamond and Thomas Barbour.

Fig. 5. Gonatodes fuscus (Hallowell). Nat. size.

M. C. Z. 12,301. Guantanamo, Cuba. C. T. Ramsden.

E. N. Fischer, del. 

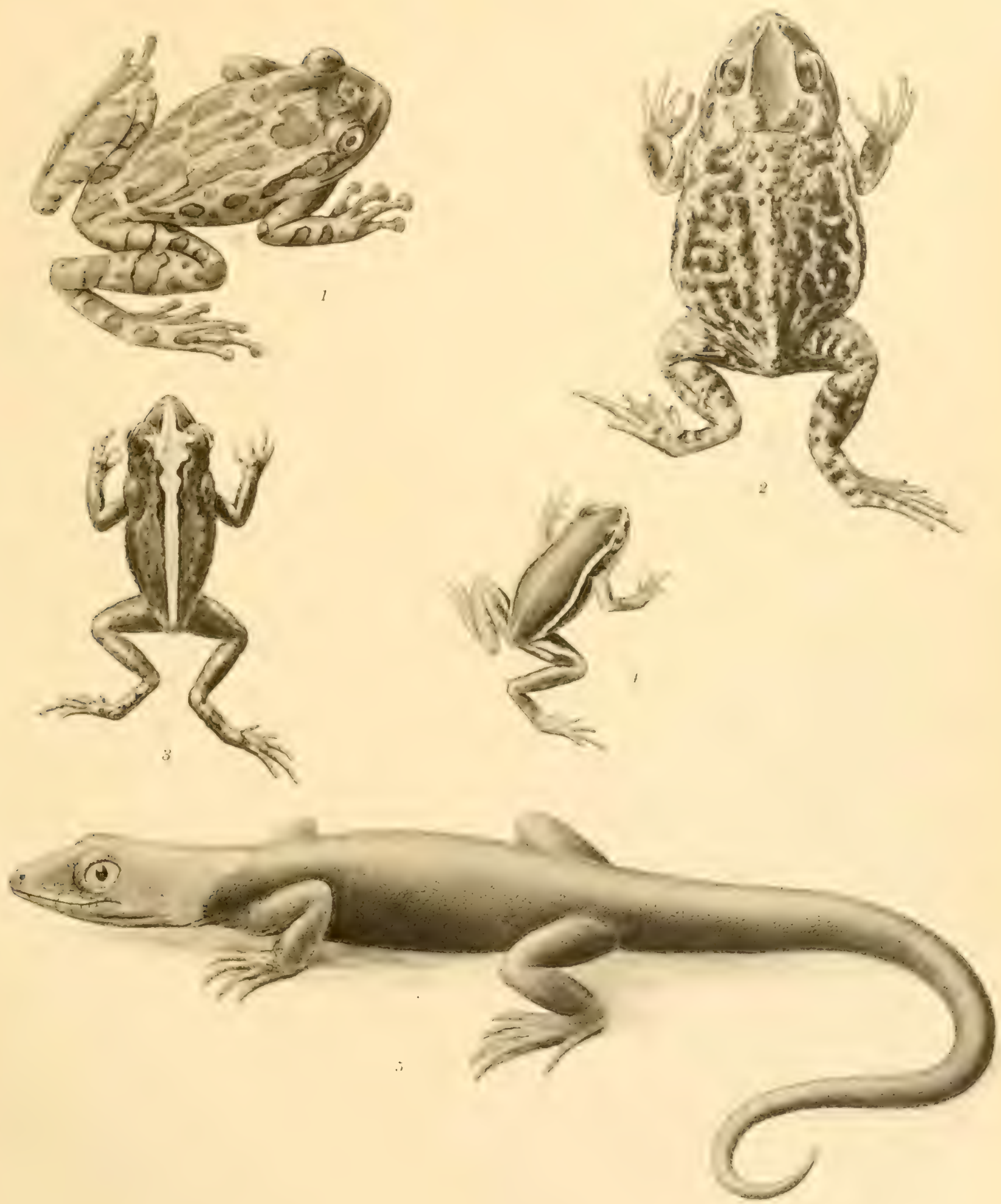

PATE 2. 


\section{PLATE 2.}

Fig. 1. Sphaerodactylus torrei Barbour. $3 \times$ nat, size.

M. C. Z. 8,510 Type. Cabo Cruz, Cuba. Thomas Barbour.

Fig. 2. The same. $2 \frac{1}{2} \times$ nat. size.

M. C. Z. 8,508. Guantanamo, Cuba. Thomas Barbour and C. T. Ramsden.

Fig. 3. Sphaerodactylus elegans MacLeay. $4 \times$ nat. size.

M. C. Z. 10,910. San Antonio de los Baños, Cuba. Thomas Barbour.

Fig. 4. Sphaerodactylus cinereus MacLeay. $2 \times$ nat. size.

M. C. Z. 10,814. San Diego de los Baños, Cuba. Rosamond and Thomas Barbour.

E. N. Fischer, del. 

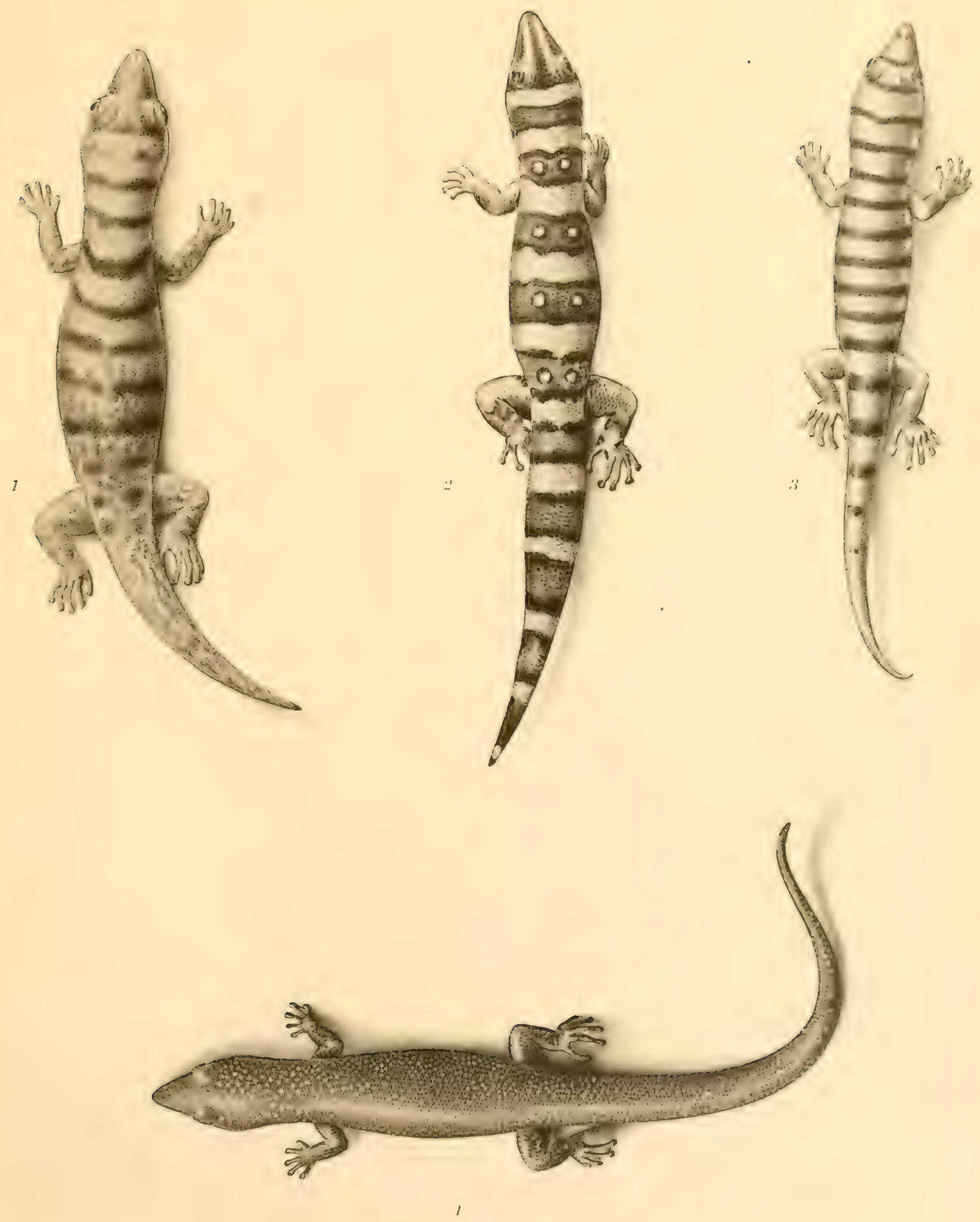

PLATE 3. 
PLATÉ 3.

Fig. 1. Sphaerodactylus nigropunctatus Gray. $3 \times$ nat. size.

M. C. Z. 8,536. Monte Libano, Guantanamo, Cuba. C. T. Ramsden.

Fig. 2. Sphaerodactylus notatus Baird. $3 \times$ nat. size.

M. C. Z. 8,513. Monte Libano, Guantanamo, Cuba. Thomas Barbour. C. T. Ramsden.

Fig. 3. Sphaerodactylus scaber. Barbour and Ramsden. $2 \frac{1}{2} \times$ nat. size.

M. C. Z. 7,952. Sierra de Jatibonico, Cuba. Barnum Brown.

Fig. 4. Anolis loysiana (Cocteau). $3 \times$ nat. size.

M. C. Z. 8,511. Los Negros, Jiguani, Sierra Maestra, Cuba. Thomas Barbour.

E. N. Fischer, del. 

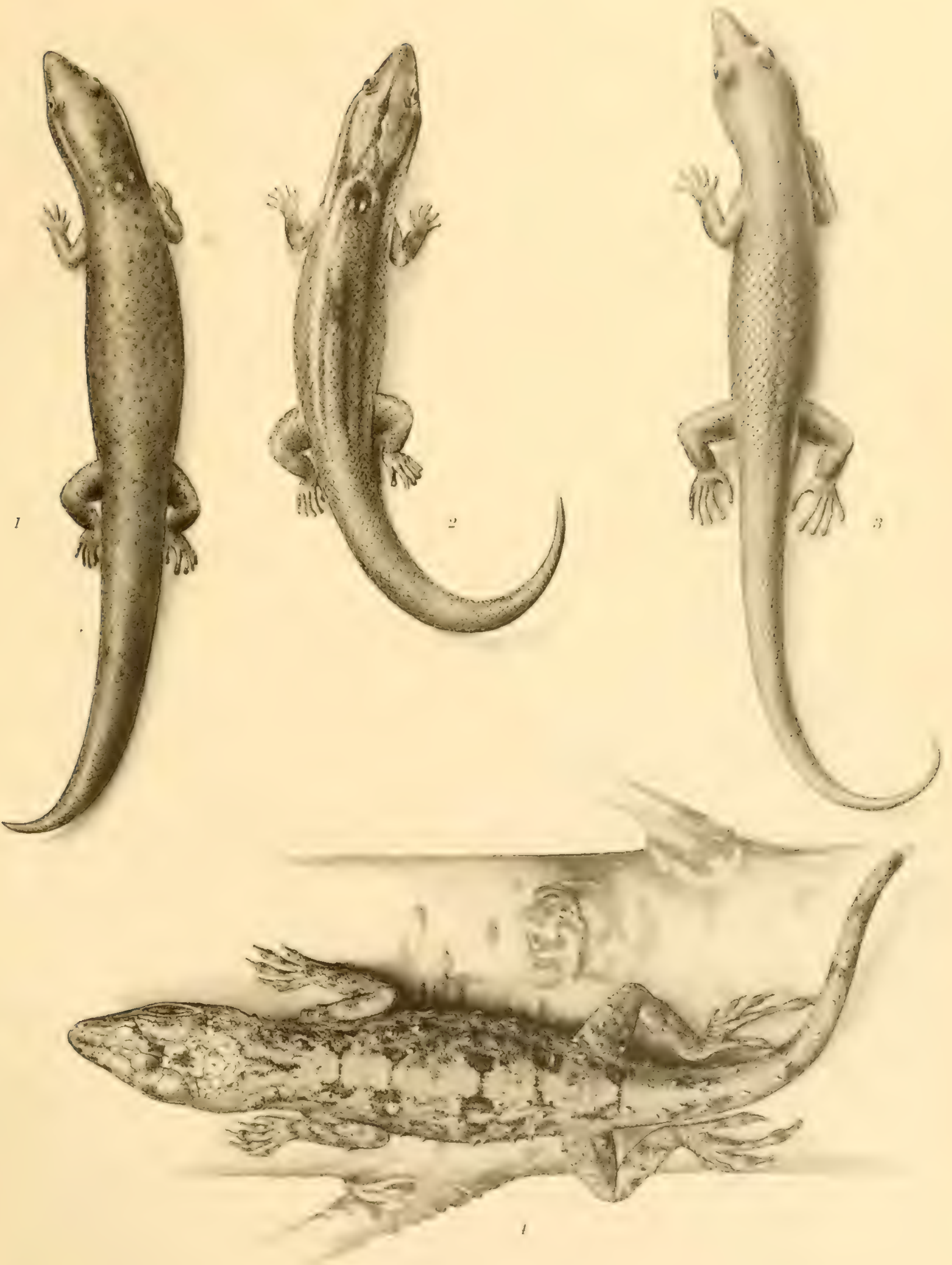


\section{.}


PLATE 4 


\section{PLATE 4.}

Fig. 1. Anolis cyanopleurus Cope. $3 \times$ nat. size. British Museum 65.6. 12.18. Cuba. Juan Gundlach.

Fig. 2. Cricolepis typica (Gundlach and Peters). $3 \times$ nat. size.

M. C. Z. 8,512. Cabo Cruz, Oriente, Cuba. Thomas Barbour.

E. N. Fischer, del. 

PLATE \%. 
PLATE 5.

Colour-pattern around middle of body.

Fig. 1. Tropidophis melanurus (Schlegel). $3 \times$ nat. size,

M. C. Z. 10,901. Cienaga de Zapata, Cuba. Thomas Barbour.

Fig. 2. Tropidophis pardalis (Gundlach). $4 \times$ nat. size.

M. C. Z. 10,840. San Antonio de los Baños, Cuba. Thomas Barbour.

Fig. 3. Tropidophis maculatus (Bibron). $4 \times$ nat. size,

M. C. Z. 12,141. Soledad near Cienfuegos, Cuba. Thomas Barbour.

E. N. Fischer, del. 

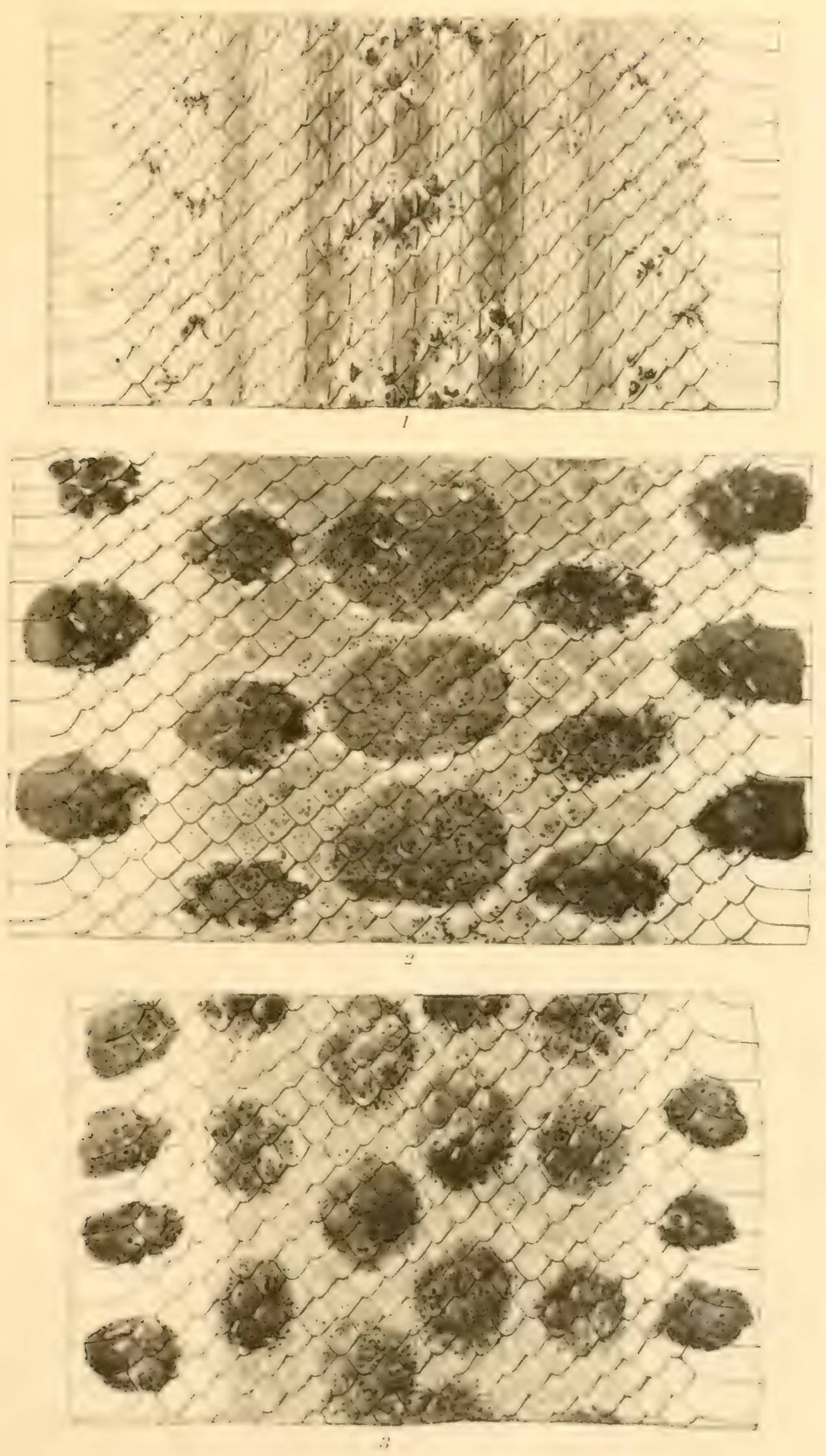

PLATE 6. 


\section{PLATE 6.}

Fig. 1. Eleutherodactylus plicatus Barbour. $4 \times$ nat. size.

M. C. Z. 3,056 Type. Monte Libano, Guantanamo, Cuba. C. T. Ramsden.

Fig. 2. Eleutherodactylus auriculatus (Cope). $4 \times$ nat. size.

M. C. Z. 4,175. Valley of Luis Lazo, western Cuba. Thomas Barbour. Open mouth.

Fig. 3. The same.

Manus.

Fig. 4. Anolis lucius Duméril and Bibron. $6 \frac{1}{2} \times$ nat. size.

M. C. Z. 8,493. Abra del Rio Yumuri, Matanzas, Cuba. Thomas Barbour.

Fig. 5. Anolis bremeri Barbour.

M. C. Z. 7,889. Herradura, Pinar del Rio, Cuba. Thomas Barbour.

Fig. 6. Anolis cyanopleurus Cope. $15 \times$ nat. size

(Bocourt, Miss. sci. Mexique, pl. 16, fig. 29).

British Museum. 65. 6.12-18. Cuba. Juan Gundlach.

Squamation of midregion of the tail.

E. N. Fischer, del. 

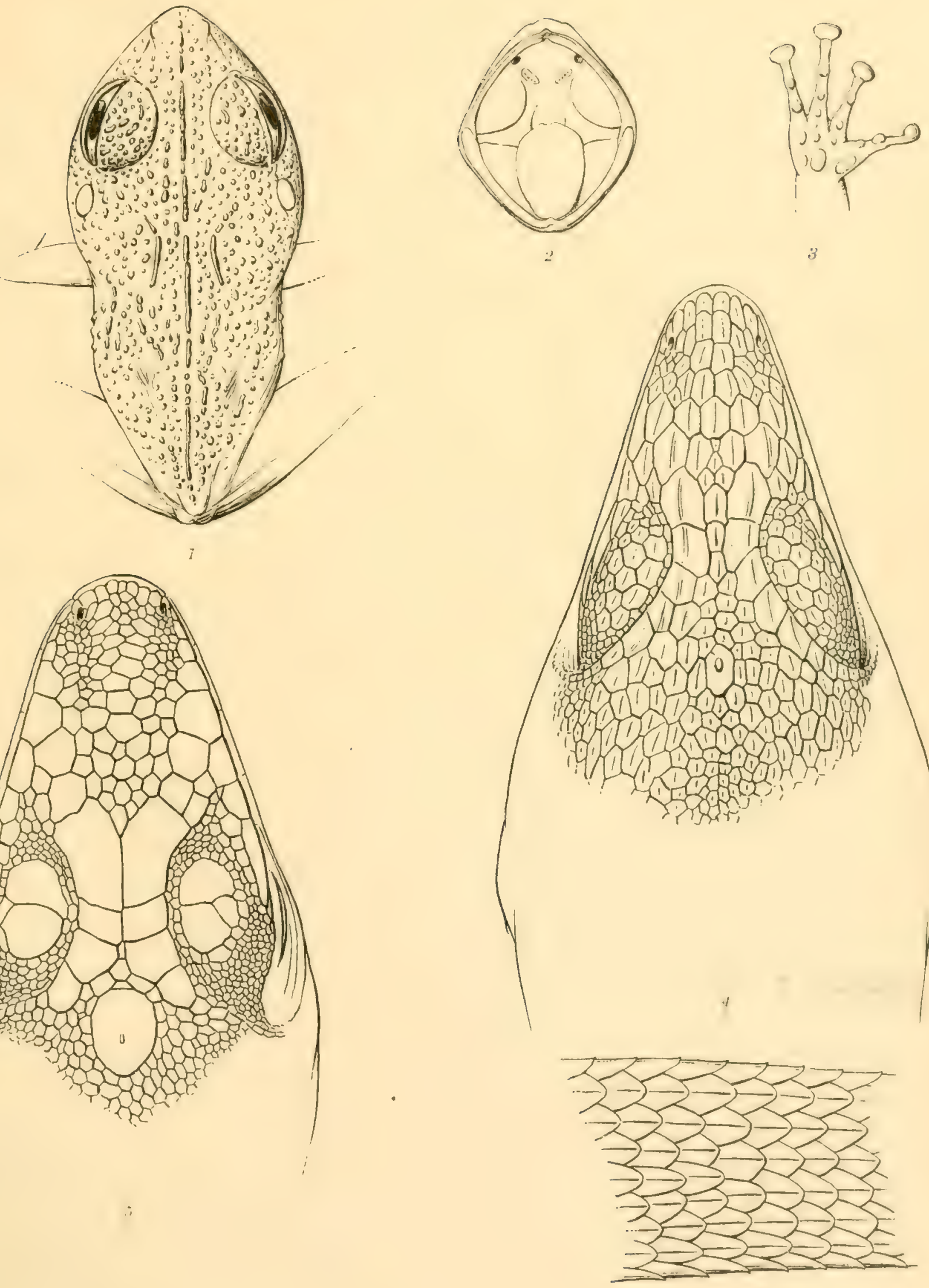

I'LATE 7 . 
PI.ATE 7.

Top of head

Fig. 1. Anolis angusticeps Hallowell.

M. C. Z. 11,150. Sierra de Guane, western Cuba. Thomas Barbour.

Fig. 2. Anolis isolepis Cope.

M. C. Z. 8,514. Los Negros, Jiguaní, Sierra Maestra, Cuba. Thomas Barbour.

Fig. 3. Anolis greyi Barbour.

M. C. Z. 7,890 Type. City of Camagüey, Cuba. Rosamond and Thomas Barbour.

Fig. 4. Anolis loysiana (Cocteau). $10 \times$ nat. size.

M. C. Z. 8,511. Los Negros, Jiguani, Sierra Maestra, Cuba. Thomas Barbour.

Fig. 5. Anolis spectrum Peters. $12 \times$ nat. size.

(Bocourt, Miss. sci. Mexique, pl. 16, fig. 24).

Fig. 6. Anolis argillaceus Cope.

M. C. Z. 8,781. Monte Libano, Guantanamo, Cuba. C. T. Ramsden.

E. N. Fischer, del. 

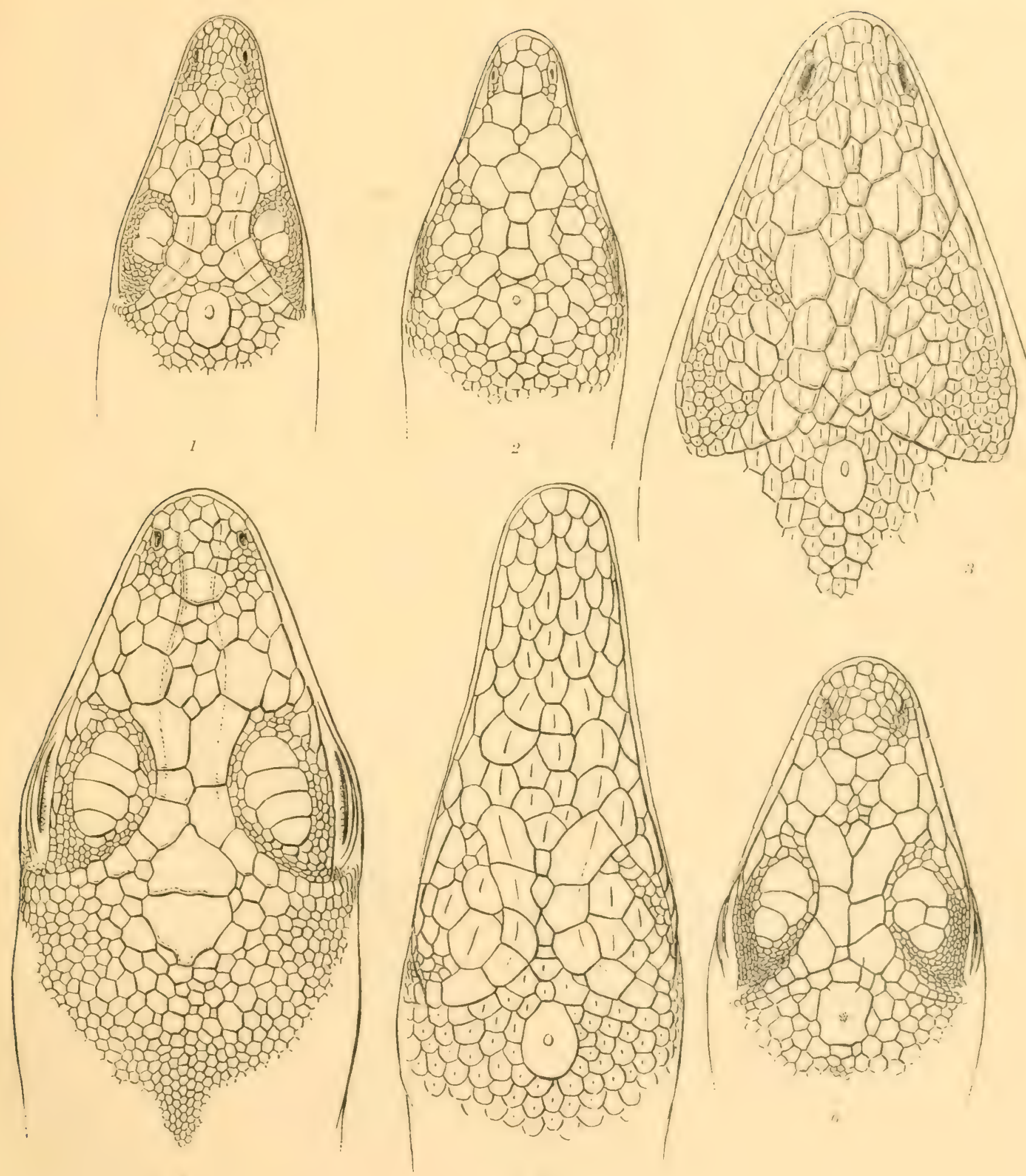

PLATE S 


\section{PLATE 8.}

Fig. 1. Anolis cyanopleurus Cope. $10 \times$ nat. size. British Museum. 65.6.12.18. Cuba. Juan Gundlach. Side of head.

Fig. 2. The same.

Top of head.

Fig. 3. The same.

(Bocourt, Miss. sci. Mexique, pl. 16, fig. 29).

Top of head.

E. N. Fischer, del. 

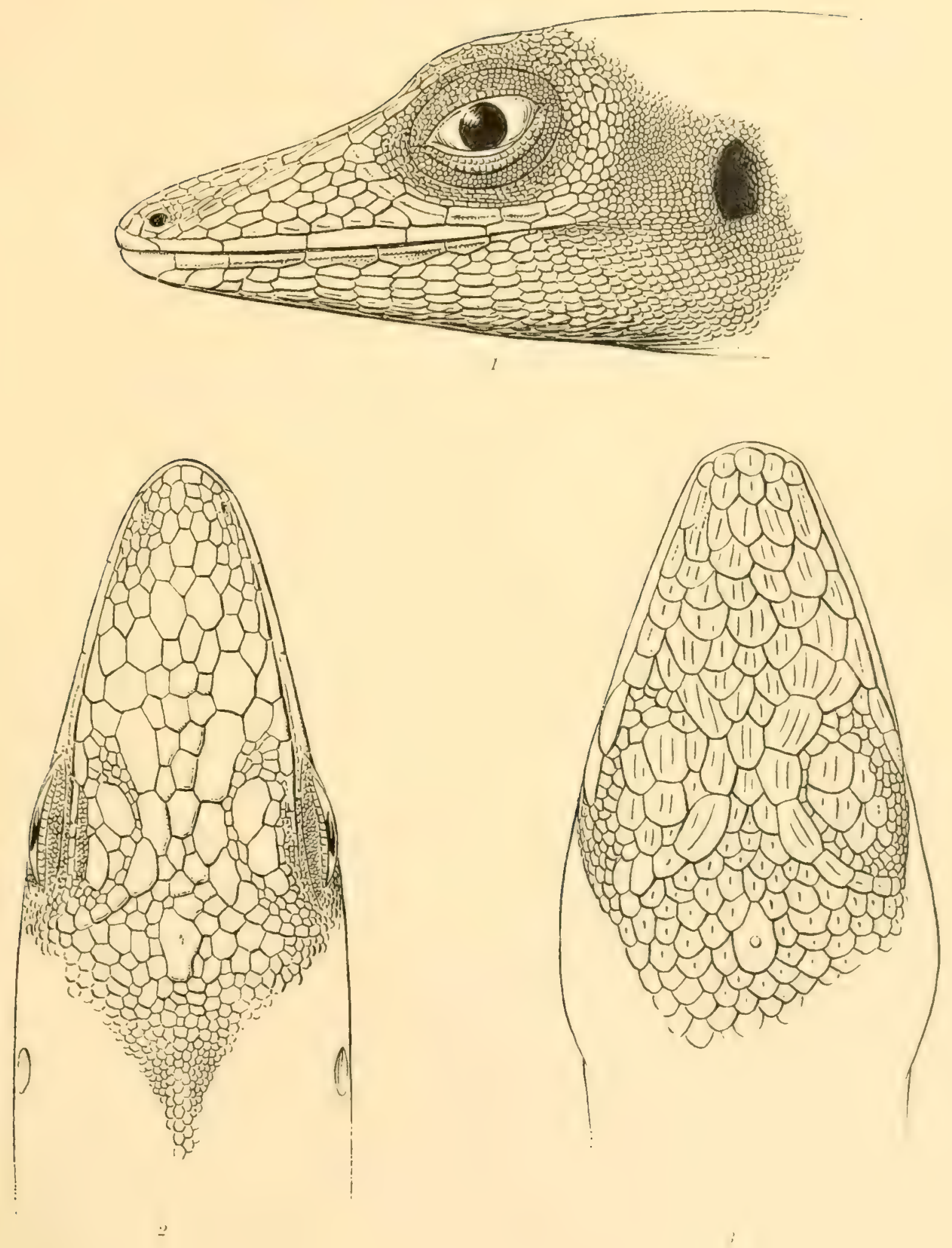



\section{PLATE 9}

Fig. 1. Anolis alutaceus Cope. $12 \times$ nat. size

M. C. Z. 7,911. Madruga, Cuba. Rosamond and Thomas Barbour.

Top of head.

Fig. 2. Anolis rubribarbus Barbour and Ramsden. $8 \times$ nat. size.

M. C. Z. 11,868 Paratype. El Puerta de Cananova, near Sagua de Tánamo, Oriente, Cuba.

V. J. Rodriguez y Verrier.

Top of head.

Fig. 3. The same.

Section of the tail, to show squamation of the "fin."

E. N. Fischer, del. 

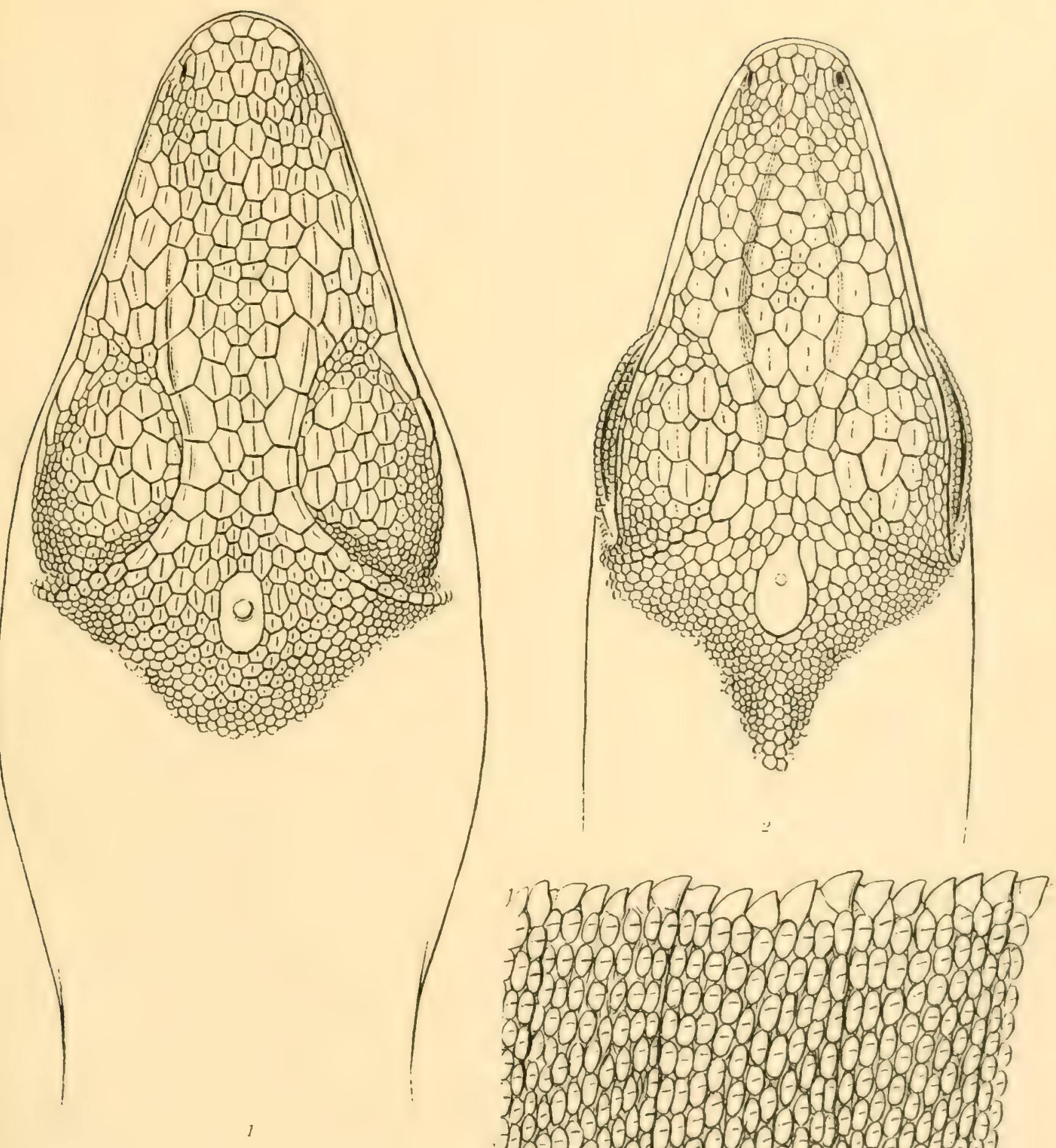

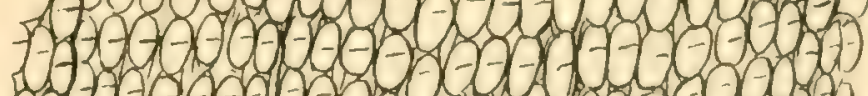

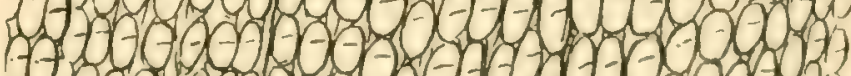

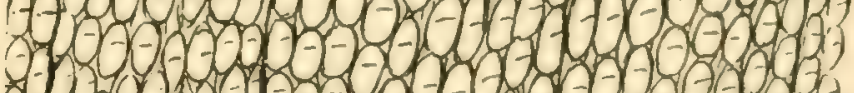

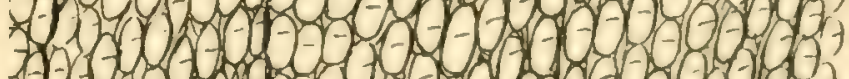

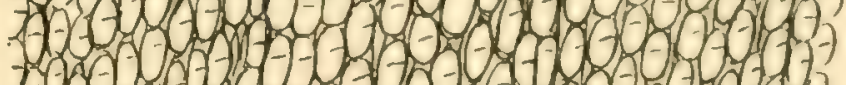
Hon-

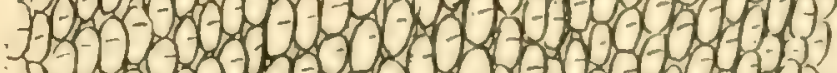

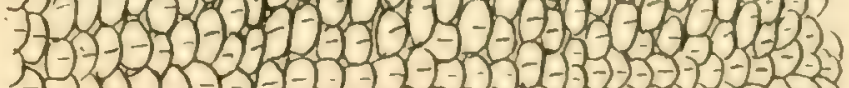

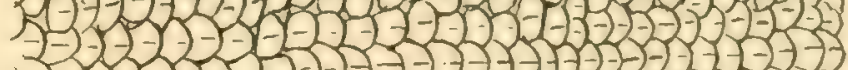

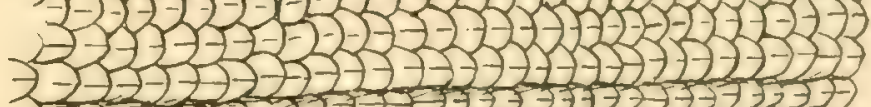

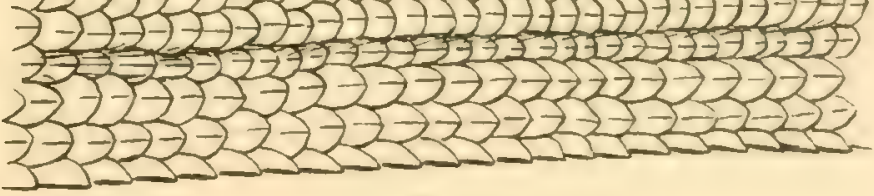



PLATE 10. 
PLATE 10.

Top of head.

Fig. 1. Anolis quadriocellifer Barbour and Ramsden.

M. C. Z. 11,867. Ensenada de Cajon, Cabo San Aptonio, Cuba. Carlos de la Torre.

Fir. 2. Anolis allogus Barbour and Ramsden.

M. C. Z. 8,433. Monte Libano, Guantanamo, Cuba. Thomas Barbour and C. T. Ramsden.

Fig. 3. Anolis mestrei Barbour and Ramsden.

M. C. Z. 11,285. Valley of Luis Lazo, westera Cuba. Thomas Barbour.

Fig. 4. Leiocephalus raviceps Cope. $7 \frac{1}{2} \times$ nat. size,

M. C. Z. 10,928 Cotype. Monte Verde, eastern Cuba. Charles Wright.

Fir. 5. Leiocephalus macropus Cope.

M. C. Z. 10,930 Cotype. (Monte Verde?) eastern Cuba. Charles Wright.

E. N. Fiseher, del. 

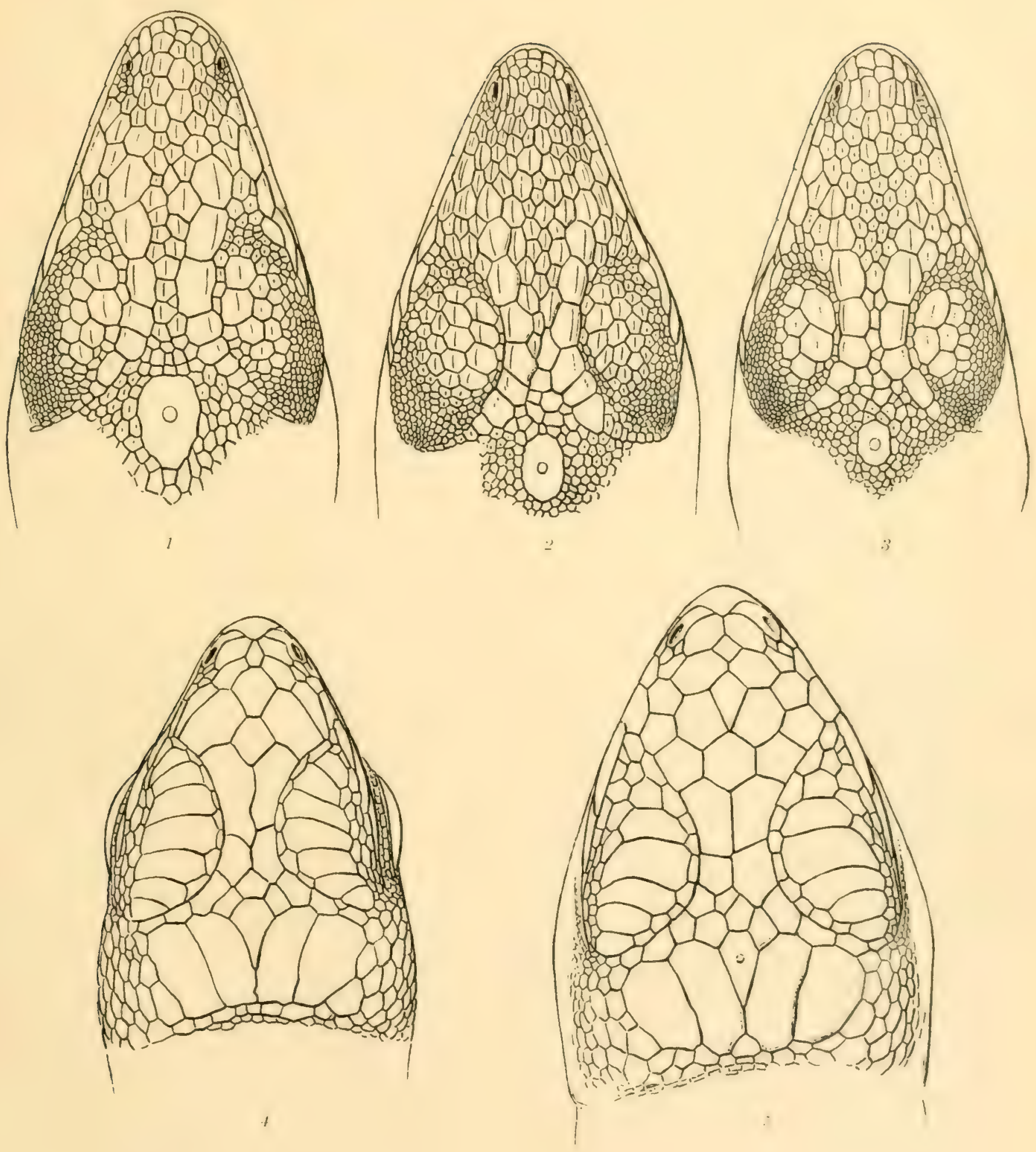

PLATE 11. 


\section{PLATE 11.}

Fig. 1. Cricolepis typica (Gundlach and Peters). $10 \times$ nat. size.

M. C. Z. 8,512. Cabo Cruz, Oriente, Cuba. Thomas Barbour.

Top of head.

Fig. 2. Cyclura macleayi Gray.

(Barbour and Noble, Bull. M. C. Z., 1916, 60, plate 2.)

M. C. Z. 11,050. Valley of Luis Lazo, western Cuba. Carlos de la Torre and Thomas Barbour. Side of head.

Fig. 3. The same.

Top of head.

Fig. 4. Typhlops lumbricalis (Linné). $14 \times$ nat. size.

M. C. Z. 7,929. Soledad, near Cienfuegos, Cuba. Rosamond and Thomas Barbour. Top of head.

Fig. 5. The same.

Side of head.

Fig. 1, 4, 5. E. N. Fischer, del.

Fig. 2, 3. George Nelson, photo. 

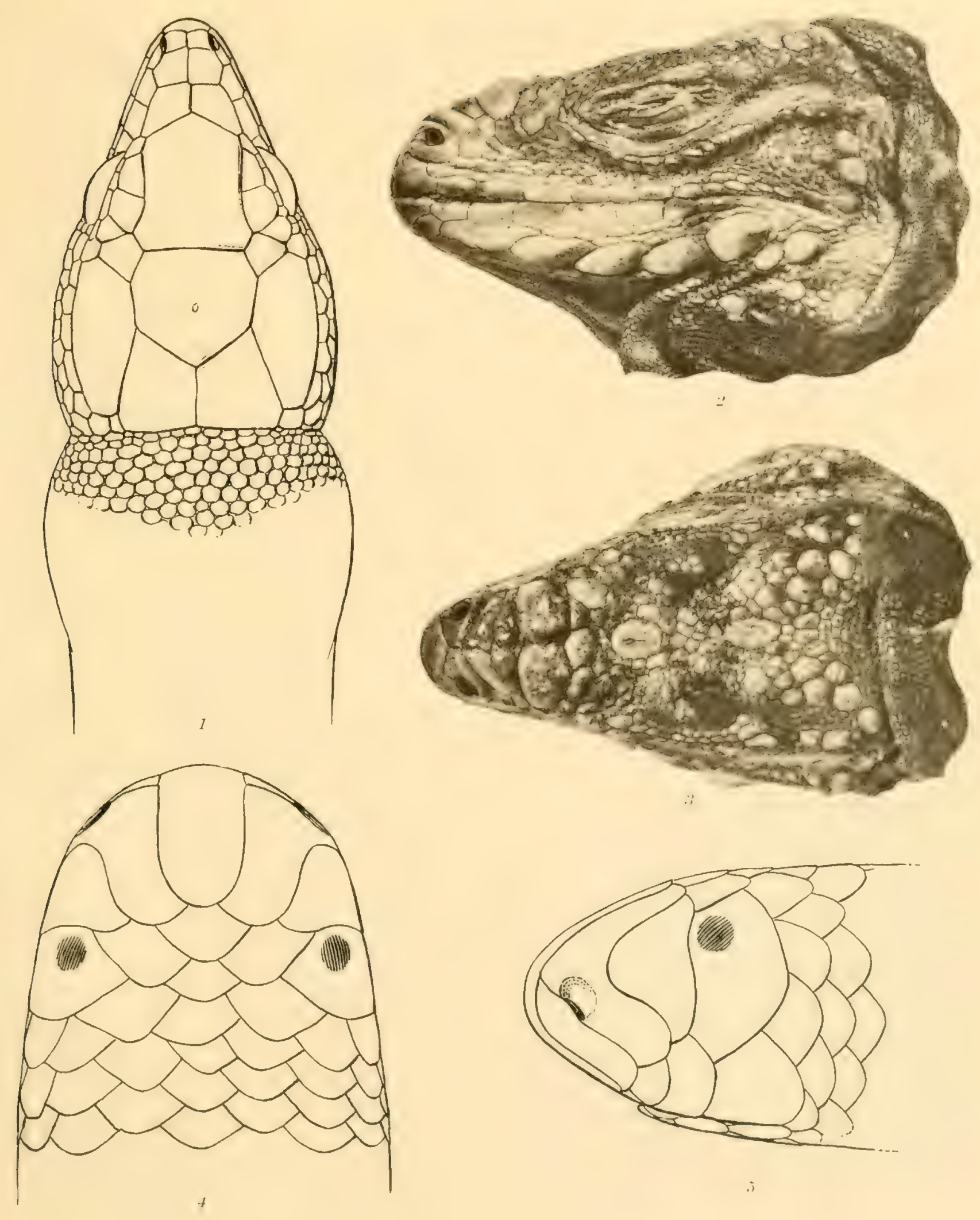


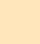


PLATE 12. 
PLATE 12.

Fig. 1. Crocodylus acutus Cuvier.

M. C. Z. 10,920 . Isle of Pines. W. R. Zappey.

Fig. 2. Crocodylus rhombifer Cuvier.

M. C. Z. 12,081. West coast of Ensenado de Cochinos, southern Cuba. Thomas Barbour. George Nelson, photo. 

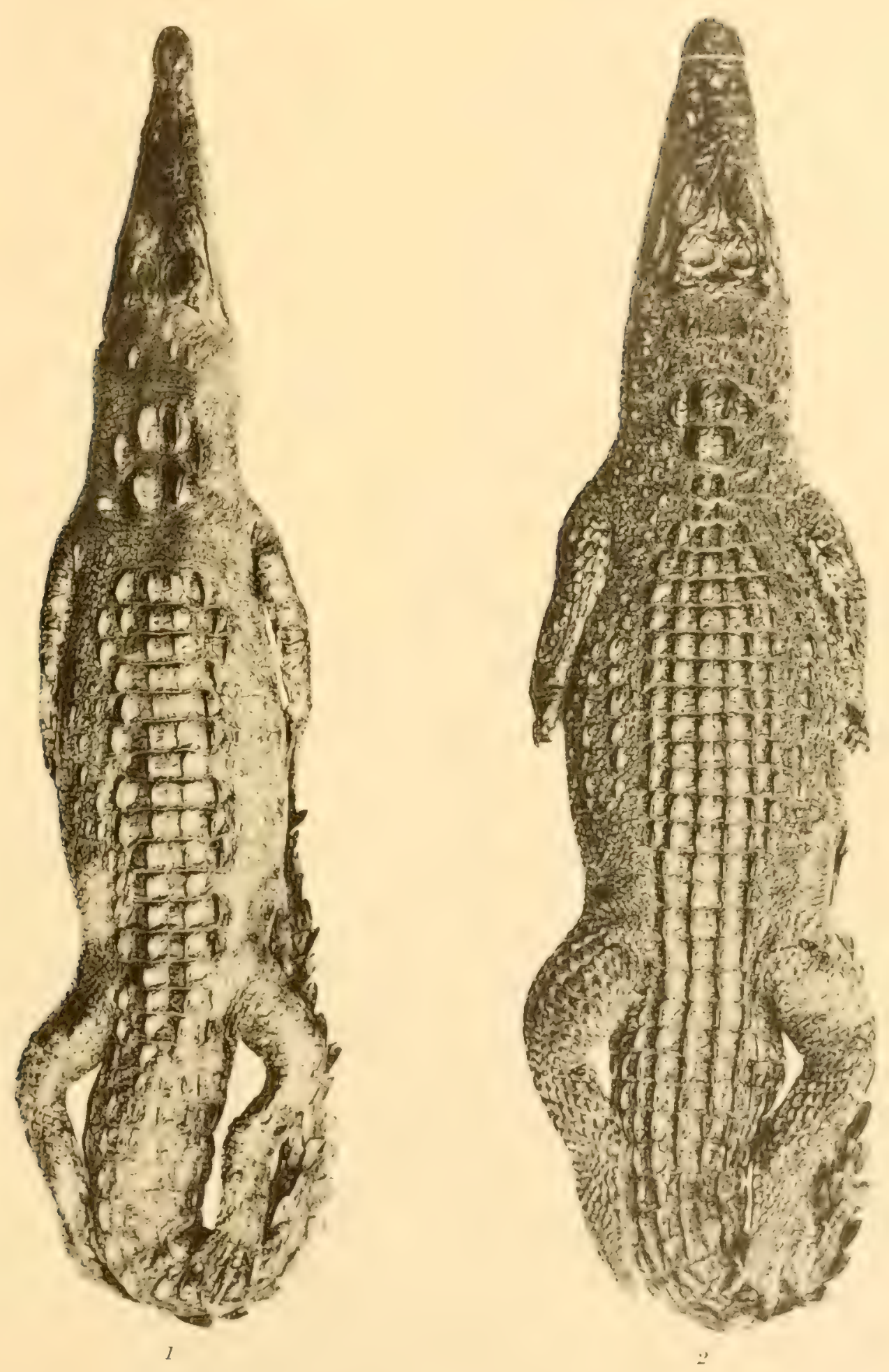

PLATE 13. 


\section{PLA'TE 13.}

Fig. 1. Bufo longinasus Stejneger.

U. S. N. M. 27,419 Type. El Guamá, Pinar del Rio City, Cuba. William Palmer and J. H. Riley.

Fig. 2. Bufo peltacephalus Tschudi.

U. S. N. M. 28,024. Nueva Gerona, Island of Pines, William Palmer and J. H. Riley.

Top of head.

Fig. 3. Eleutherodactylus ricordii (Duméril and Bibron).

U. S. N. M. 27,415. Pinar del Rio, Cuba. William Palmer and J. H. Riley.

Top of head.

Fig. 4. The same.

Side of head

Fig. 5. The same.

Open mouth.

Fig. 6. Eleutherodactylus dimidiatus (Cope).

U. S. N. M. 29,767. Guamá, Oriente, Cuba. B. S. Bowdish

Top of head.

Fig. 7. The same.

Side of head.

Fig. 8. The same.

Open mouth.

Fig. 9. Eleutherodactylus cuneatus (Cope).

U. S. N. M. 26,654. San Diego de los Baños, Cuba. William Palmer and J. H. Riley. Top of head.

Fig. 10. The same.

Side of head.

Fig. 11. The same. Open mouth.

Fig. 12. Eleutherodactylus varians (Gundlach and Peters).

U. S. N. M. 27,417. El Guamá, Pinar del Rio, Cuba. William Palmer and J. H. Riley.

Top of head.

Fig. 13. The same.

Side of head.

Fig. 14. The same.

Open mouth.

Fig. 1. Stejneger, Proc. U. S. N. M., 1905, 28.

Fig. 2-14. Stejneger, Proc. U. S. N. M., 1917, 53. 

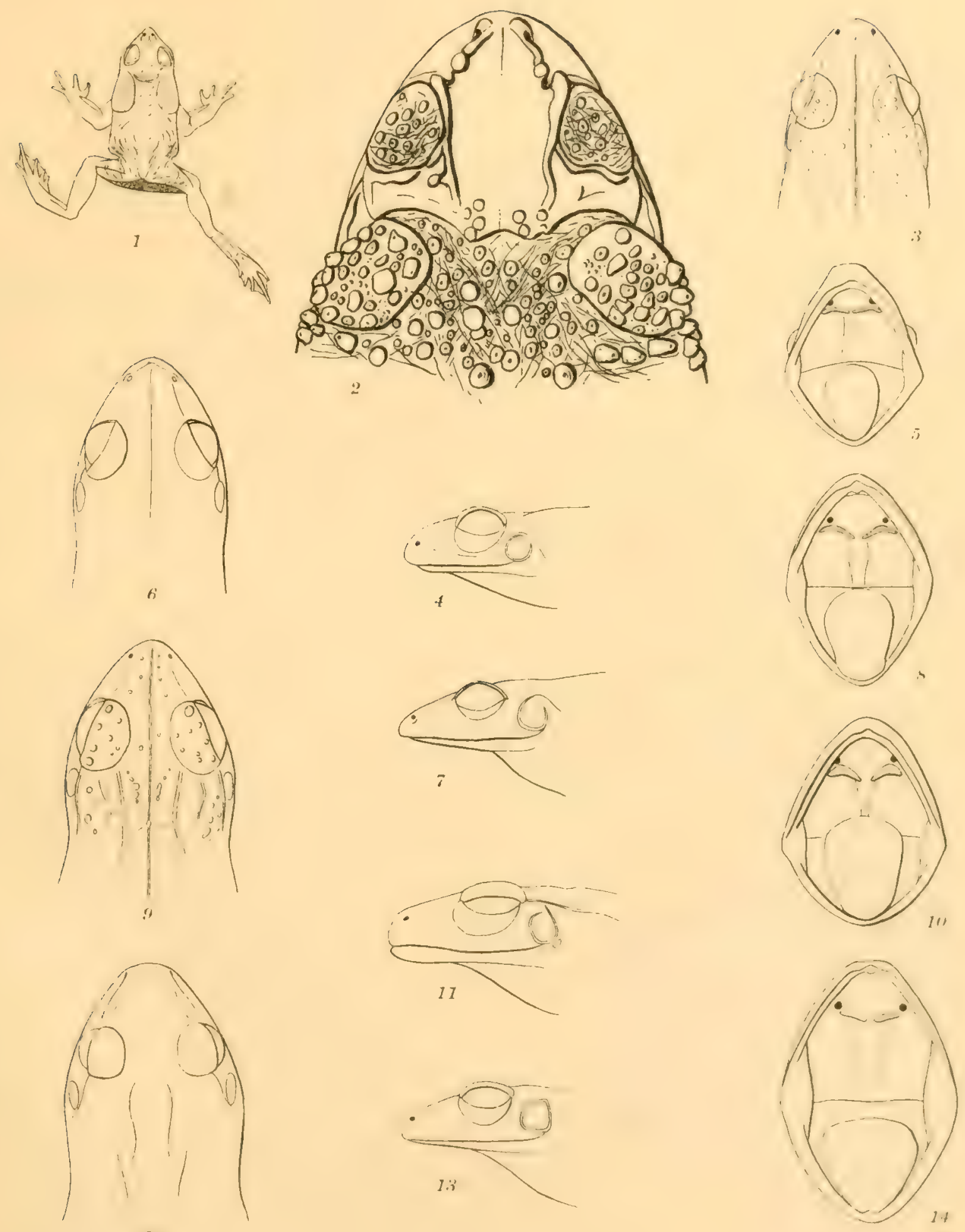


\section{•}


PLATE 14. 


\section{PLATE 14.}

Fig. 1. Tarentola cubana (Gundlach and Peters).

U.S. N. M. 29,777. Guamá, Oriente, Cuba. B. S. Bowdish.

Fig. 2. Chamaleolis chamaeleontides (Duméril and Bibron).

U. S. N. M. 27,502. San Diego de los Baños, Cuba. William Palmer and J. H. Riley. Side of head.

Fig. 3. The same.

Lepidosis of the side of the back.

Fig. 4. Deiropteryx vermiculata (Dumćril and Bibron).

U. S. N. M. 27,335. El Guamá, Pinar del Rio, Cuba. William Palmer and J. H. Riley. Top of head.

Fig. 5. Anolis equestris Merrem.

U. S. N. M. 27,504. San Diego de los Baños, Cuba. William Palmer and J. H. Riley. Top of head.

Fig. 6. Anolis argenteolus Cope.

U. S. N. M. 26,777. Near Santiago de Cuba, Cuba. Leonhard Stejneger.

Top of head.

Fig. 7. Anolis sagrei Duméril and Bibron.

U. S. N. M. 26,771. Santiago de Cuba, Cuba. Leonhard Stejneger.

Top of head.

Fig. 8. Anolis homolechis Cope.

U. S. N. M. 26,770. Santiago de Cuba, Cuba. Leonhard Stejneger.

Top of head.

Fig. 9. Anolis porcatus Gray.

U. S. N. M. 26,776. Sañtiago de Cuba, Cuba. Leonhard Stejneger.

Top of head.

Fig. 10. Norops ophiolepis (Cope).

U. S. N. M. 27,367. Pinar del Rio, Cuba. William Palmer and J. H. Riley. Side of head.

Fig. 11. Leiocephalus carinatus Gray.

U. S. N. M. 26,768. Santiago de Cuba, Cuba. Leonhard Stejneger.

Top of head.

Fig. 12. Leiocephalus cubensis (Gray).

U. S. N. M. 27,375. Pinar del Rio Cuba. William Palmer and J. H. Riley.

Top of head.

Fig. 13. Celestus de la sagra (Cocteau).

U. S. N. M. 27,647. Cabañas, Cuba. William Palmer and J. H. Riley. Top of head.

Fig. 14. Ameiva auberi Cocteau.

U. S. N. M. 26,765. Santiago de Cuba. William Palmer and J. H. Riley.

Top of head.

Stejneger, Proc. U. S. N. M., 1917, 63. 

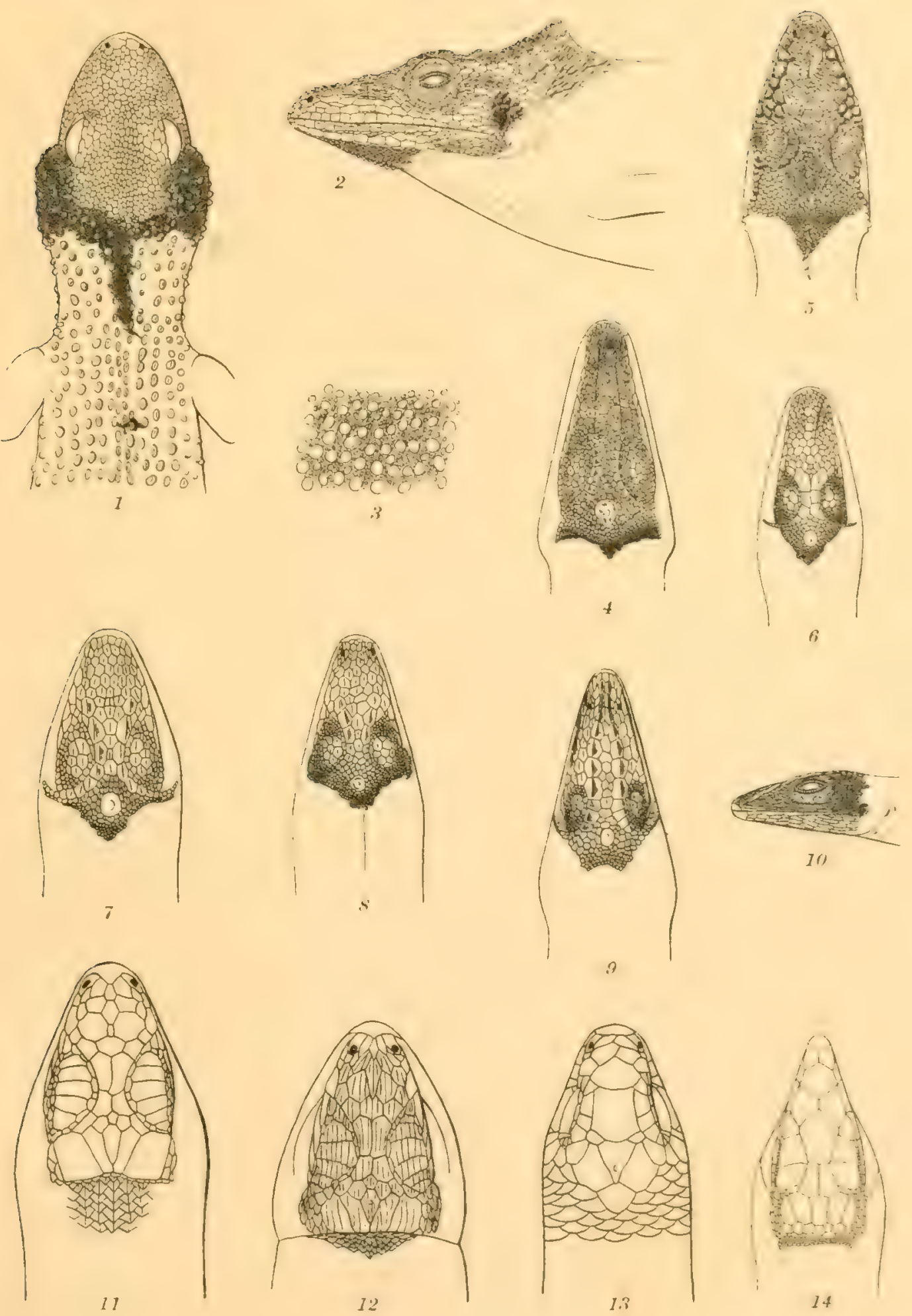
PLATE 15. 
P'LA'TE 15.

Fig. 1. Cadea blanoides Stejneger.

U. S. N. M. 27,845. San Diego de los Baños, Cuba. William Palmer and J. H. Riley.

Top of head.

Fig. 22 Amphisbaena cubana P'eters.

U. S. N. M. 26,364. Matanzas, Cuba. J. W. Daniel, Jr.

Top of head.

Fig. :3. Epierates angulifer Bibron,

U. S. N. M. 27,498. San Diego de los Baños, Cuba. William Palmer and J. H. Riley. Side of head.

Fig. 1. Tropidophis semicinctus (Gundlach and Peters).

U. S. N. MI. 26,361. Matanzas, Cuba. J. W. Daniel, Jr.

Top of head.

Fig. 5. The same.

Side of head.

Fig. 6. The same.

Color pattern and section through middle of the body.

Fig. 7. Alsophis angulifer (Bibron).

U. S. N. M. 27,501. San Diego de los Baños, Cuba. William Palmer and J. H. Riley. Top of head.

Fig. 8. Leimadophis andreae (Reinhardt and Lütken).

U.S. N. MI, 26,76t. Santiago de Cuba, Cuba. Leonhard Stejneger.

Top of head.

Fì. 9. Tretanorhinus variabilis Duméril and Bibron.

U. S. N. M. 27,393. El Guamá, Pinar del Rio, Cuba, William Palmer and J. H. Riley.

Top of head.

Fig. 10. Arrhyton taeniatum Günther.

U. S. N. M 12,421 Type of A. fulvum Cope. Cuba.

Side of head.

Fig. 11. The same.

Color pattern at about middle of the body.

Fig. 12. Arrhyton vittatum (Gundlach and Peters).

U.S. N. M. 5,781 Type of A. bivittatum Cope. Cuba.

Side of head.

Fig. 13. The same.

Color pattern at about middle of the body.

Iig. 14. Pseudemys palustris (Gmelin).

U. S. N. M. 27,629. Cabañas, Cuba. William Palmer and J. H. Riley.

Top of carapace.

Fig. 15. The same.

Side view of shell.

Fig. 16. The same.

Lower view of plastron.

Stejneger, Proc. U. S. N. M., 1917, 53 

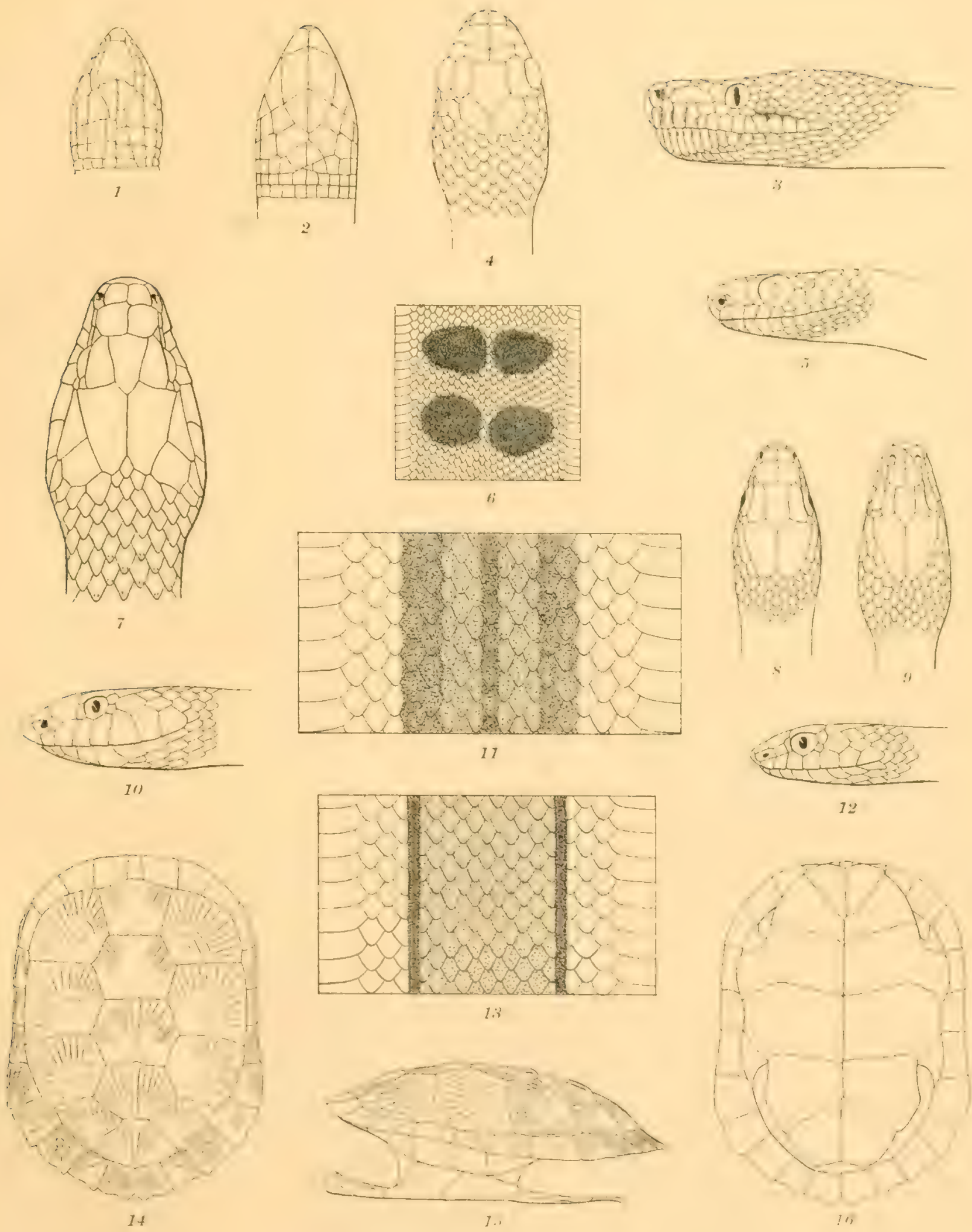






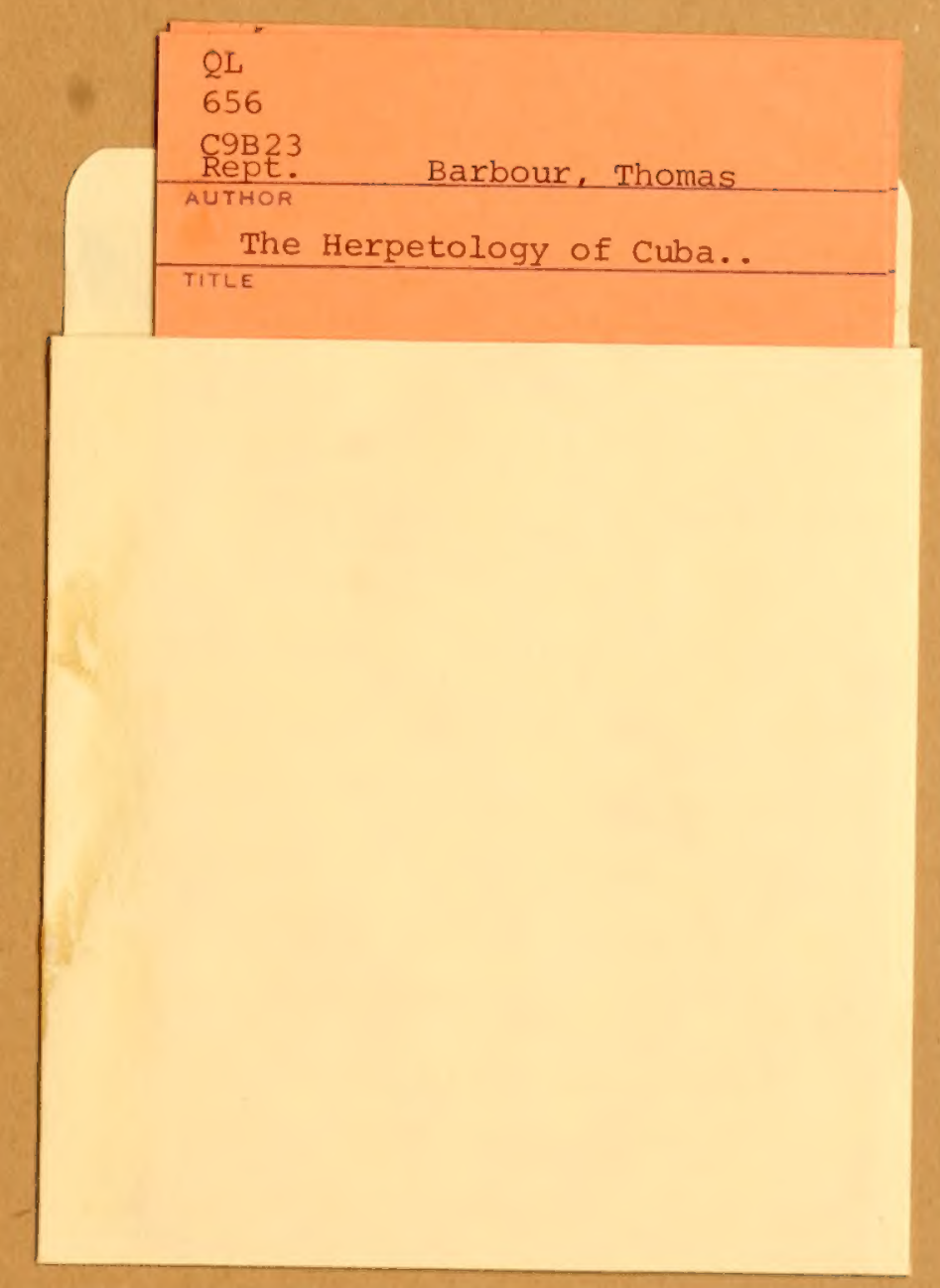



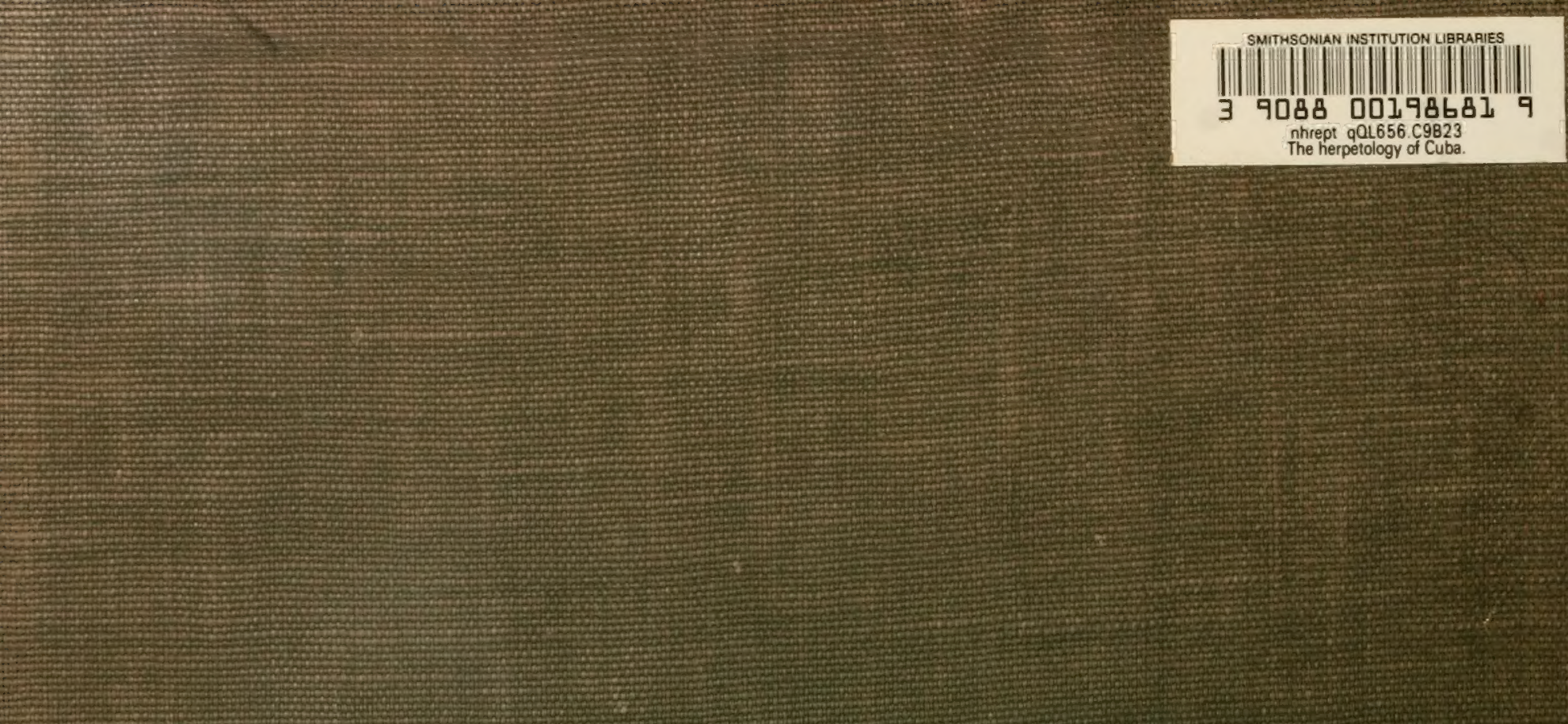